\author{
Universidade de São Paulo \\ Faculdade de Filosofia, Letras e Ciências Humanas \\ Departamento de Letras Modernas \\ Estudos Linguísticos, Literários e Tradutológicos em Francês
}

A REPRESENTAÇÃO DO ARRIVISMO SOCIAL NOS ROMANCES LE ROUGE ET LE NOIR DE STENDHAL E A MÃO E A LUVA DE MACHADO DE ASSIS

Maria Elvira Lemos da Silva

São Paulo 


\author{
Universidade de São Paulo \\ Faculdade de Filosofia, Letras e Ciências Humanas \\ Departamento de Letras Modernas \\ Estudos Linguísticos, Literários e Tradutológicos em Francês
}

\title{
A REPRESENTAÇÃO DO ARRIVISMO SOCIAL NOS ROMANCES LE ROUGE ET LE NOIR DE STENDHAL E A MÃO E A LUVA DE MACHADO DE ASSIS
}

\begin{abstract}
Maria Elvira Lemos da Silva
Dissertação apresentada ao programa de Pós-Graduação em Estudos Linguísticos, Literários e Tradutológicos em Francês da Universidade de São Paulo para a obtenção do título de Mestre Orientador: Prof. Dr. Gilberto Pinheiro Passos
\end{abstract}

São Paulo 
À minha mãe,

Maria Regina 
Agradecimentos

\author{
À CAPES, \\ Pelo apoio financeiro. \\ Ao Professor Gilberto Pinheiro Passos, \\ Pela generosidade.
}

A Mônica Cristina Corrêa,

Pelo incentivo.

Ao meu pai, Clayton, e aos meus irmãos, João, Isabella e Jéssica, Pelo apoio fundamental.

A Eivy Cristina Oliveira e Danillo Aguiar,

Pela amizade de todos os dias.
A Adolfo Yoshihara,
Pelo companheirismo. 


\section{Resumo}

O arrivismo social, tema largamente abordado na literatura do século XIX, tem uma de suas grandes representações em na personagem Julien Sorel do romance Le rouge et le noir (1830) de Stendhal. Sorel é uma personagem verdadeiramente engendrada pelos acontecimentos históricos e sociais da época em que o romance foi escrito. Beneficiando-se de seu conhecimento dolatim e da Bíblia, vai aos poucos conquistando posições vantajosas nas casas em que é acolhido como preceptor e secretário.

Escrito quase meio século depois de Le rouge et le noir, A mão e a luva (1874), do brasileiro Machado de Assis se passa no Rio de Janeiro do Segundo Reinado. Diferentemente de Stendhal, Machado de Assis não constrói a trama da heroína Guiomar - a partir de fatos históricos específicos. Entretanto, a obra brasileira propicia ao leitor uma aguçada percepção dos costumes vigentes no Segundo Reinado, em mais de uma esfera social. Do nascimento humilde à vida adulta confortável, a trajetória de Guiomar traz à tona nuanças de uma sociedade em transformação.

Esse estudo tem por objetivo observar a construção e o desenvolvimento dos protagonistas - Julien Sorel e Guiomar - em seus respectivos contextos literários, a fim de estabelecer, entre as narrativas, possíveis conexões. Não obstante, ao longo do trabalho, para além das semelhanças, tais como capacidade de adaptação e ambição, pôde-se perceber diferenças substanciais entre Julien e Guiomar: enquanto aquele 
destaca-se por não se adequar à norma social estabelecida, esta encaixa-se perfeitamente na sociedade em que vive, dominando amplamente suas regras. É o que tentaremos demonstrar e o que faz o objeto dessa dissertação. 


\begin{abstract}
The theme of social ambition, widely explored in $19^{\text {th }}$ century literature, finds in the character Julien Sorel of Stendhal's 1830 novel The Red and the Black one of its greatest representations. Sorel is truly engendered by the historical and social events of the novel's period. By taking advantage of his knowledge of Latin and the Bible, he gradually gains a privileged position in those houses where he comes to work as a tutor and secretary.

Written almost half a century after The Red and the Black, The Hand and the Glove (1874), by Brazilian writer Machado de Assis, takes place in Rio de Janeiro during the 1850s. Unlike Stendhal, Machado does not build his heroine Guiomar's plot from specific historical events. Yet the novel offers the reader a heightened perception of life during the Second Reign, in more than one social class. From her humble origins to her comfortable adult life, Guiomar's trajectory brings out the nuances of a changing society.

The present study observes the construction and development of both protagonists - Sorel and Guiomar - in their respective literary contexts, in order to establish possible connections between the two narratives. Their similarities notwithstanding, such as their adaptability and ambition, this research has also identified substantial differences between Sorel and Guiomar. While he stands out for not conforming to the established social norms, she becomes perfectly adapted to the social environment where she lives, in complete control of its rules. This is the main object and argument of this dissertation.
\end{abstract}




\section{Résumé}

L'arrivisme social, thème largement traité dans la littérature au XIXè siècle, trouve une grande représentation chez Julien Sorel, personnage du roman Le rouge et le noir (1830) de Stendhal. Sorel est un personnage tout à fait engendré au sein des événements historiques et sociaux de l'époque où fut écrit ce roman. Se servant de ses connaissances du latin et de la Bible, il conquiert, peu à peu, des positions avantageuses dans les maisons où on l'accueille en tant que précepteur et secrétaire.

Écrit presque un demi siècle plus tard, le roman La main et le gant (1874), du brésilien Machado de Assis, se déroule à Rio de Janeiro pendant le Second Empire. Au contraire de Stendhal, Machado de Assis ne construit pas la trame de l'heroïne Guiomar à partir des faits historiques spécifiques. L'oeuvre brésilienne permet au lecteur d'avoir un fin apperçu des moeurs de l'époque dans plus d'une couche sociale. De sa naissance simple à la vie adulte aisée, la trajectoire de Guiomar dévoile les nuances d'une société changeante.

Cette étude a pour but d'observer la construction et le développément des protagonistes - Julien Sorel et Guiomar - dans leurs contextes littéraires respectifs, afin d'établir des connexions entre ces deux récits. Toutefois, au long de ce travail, en plus des ressemblances, telles la capacité d'adaptation et l'ambition, il est possible d'y voir d'importantes différences entre Julien et Guiomar : celui-là ne s'adapte pas à la norme sociale établie, celle-ci cadre parfaitement avec la société qui l'entoure, maîtrisant entièrement ses règles. C'est ce que nous tenterons de démontrer et qui fait l'objet de cette dissertation. 


\section{Sumário}

Introdução.

\section{Capítulo I}

O heroísmo deslocado na França da Restauração e

a sociedade fluminense no Brasil do Segundo Reinado

\section{Capítulo II}

Os títulos.

Capítulo III

Variação e unidade: os ambientes de Julien e Guiomar

28

Capítulo IV

Masculino / Feminino.

44

\section{Capítulo V}

A corporificação artística "stricto sensu"

O romance de embate de classes: Le rouge et le noir.

Romance de adequação social: a baronesa e seu advogado.

O caráter "único" de Julien

O caráter apenas particular de Guiomar e Luís Alves. 
A união dos "contrários" em Le rouge et le noir.................................... 82

A união dos "iguais" em $A$ mão e a luva............................................ 87

O "desencanto" final: morte ............................................................... 91

O "encanto" final: casamento............................................................. 95

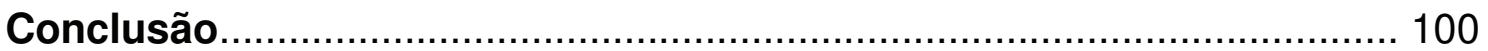

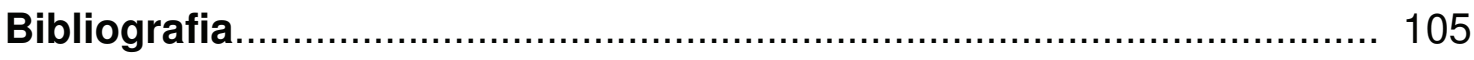

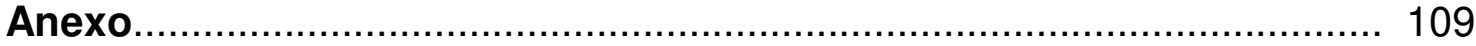




\section{Introdução}

O arrivismo social, tema largamente abordado na literatura do século XIX, tem uma de suas grandes representações em Le rouge et le noir (1830) de Stendhal. Pode-se dizer que esse é o momento em que a burguesia tem consciência plena de seu poder e as obras escritas por Stendhal e Balzac falam à sensibilidade moderna de modo particular e fundamental. Julien Sorel é uma das primeiras personagens verdadeiramente engendrada pelos acontecimentos históricos e sociais da época em que o romance foi escrito.

Julien Sorel, Eugène de Rastignac, de Le père Goriot (1834), e Lucien de Rubempré, de Illusions perdues (1843), figuram entre as figuras célebres que buscam um lugar de destaque na sociedade francesa do século XIX. Julien, beneficiado por seu conhecimento de latim e da Bíblia, vai aos poucos conquistando posições vantajosas nas casas em que é acolhido. Eugène de Rastignac, humilde estudante de direito e morador da Pensão Vauqueur, começa a freqüentar os salões parisienses e logo se mostra adaptado a eles. Lucien de Rubempré, jovem escritor, consegue deixar a pequena cidade onde vive, Angoulème, com a ajuda de sua amante e protetora, Mme de Bargeton, para tentar conquistar um espaço na imprensa parisiense.

Personagens que ilustram a mobilidade social na França daquele século, Julien, Rastignac e Lucien são exemplos de representações literárias de um mesmo tema e que, no entanto, têm percursos bem distintos. O centro gravitacional das três estórias é a adaptação à vida parisiense de personagens 
da província. A compreensão do seu modo de funcionamento àquela época é essencial na construção deste exame, pois suas regras, seus hábitos e seus caprichos dão o tom e o ritmo da trajetória dos protagonistas. No romance de Balzac, La fille aux yeux d'or (1834), temos logo no início uma longa narração a respeito de Paris que poderia ilustrar a questão do espaço nos romances mencionados acima. ${ }^{1}$ Os protagonistas vêm da província, que representaria pureza e ingenuidade para tentar a sorte na maior cidade do país. A relação das personagens com a cidade é tão importante que a capital parece ser espaço e personagem na estrutura das narrativas tal força ela exerce. ${ }^{2}$ Esse contraste será a base estrutural do romance de Stendhal.

\footnotetext{
${ }^{1}$ BALZAC, Honoré de. La fille aux yeux d'or. La Comédie Humaine V. Paris, Bibliothèque de la Pléiade/ Éditions Gallimard, p. 1039, 1042. "En voyant ce peuple exhumé, les étrangers, qui ne sont pas tenus de réfléchir, éprouvent tout d'abord un mouvement de dégout pour cette capital, vaste atelier de jouissances, d'où bientôt eux-mêmes ils ne peuvent sortir, et restent à s'y déformer volontiers. (...) Néanmoins ce peuple a ses phénomènes de vertu, ses hommes complets, sés Napoléons inconnus, qui sont le type de sés forces portées sociale dans une existence où la pensée et le mouvement se combinent moins pour y jeter de la joie que pour y régulariser l'action de la douleur."

${ }^{2}$ A frase célebre que ilustra bem essa questão é a de Rastignac ao fim de Le Père Goriot. Desiludido com o fim que teve o pai Goriot e a par do funcionamento de Paris, o arrivista, logo após o enterro do velho, exclama do alto do cemitério Père-Lachaise: "À nous deux maintenant!" A imagem de toda a cena é muito significativa: "Rastignac, resté seul, fit quelques pas vers le haut du cimitière et vit Paris tortueusement couché le long des deux rives de la Seine, ou commençaient à briller les lumières. Ses yeux s'attachèrent presque avidement entre la colonne de la place Vendôme et le dôme des Invalides, là ou vivait ce beau monde dans lequel il avait voulu pénétrer. II lança sur cette ruche bourdonnant um regard qui semblait par avance en pomper le miel, et dit ces mots grandioses: " À nous deux maintenant!"” BALZAC, Honoré de. Le Père Goriot. La Comédie Humaine III. Bibliothèque de la Pléiade/ Éditions Gallimard, p. 290.
} 
Escrito quase meio século depois de Le rouge et le noir, A mão e a luva (1874) se passa no Rio de Janeiro do Segundo Reinado, em um período de progresso cultural e industrial, com o crescimento e a consolidação da nação brasileira como país independente. No entanto, a combinação do romantismo idealista com o realismo utilitário ainda era um dos principais modelos para a narrativa brasileira. ${ }^{3}$

Pode-se dizer que as influências européias chegavam aqui com certa defasagem temporal, visto que $A$ mão e a luva e Senhora de José Alencar foram escritos na década de 1870, algum tempo depois que Madame Bovary de Gustave Flaubert, texto inovador, já havia sido publicado, em 1856. Assim, os movimentos literários francês e brasileiro relativos às obras escolhidas para este estudo, apesar das características e contexto próprios de cada país, são mais relacionáveis do que pode parecer à primeira vista. A escolha de Le rouge et le noir e $A$ mão e a luva se deve ao fato de que, em ambas as narrativas, o percurso dos protagonistas começa na primeira infância e termina no início da vida adulta. Desse modo, a observação simultânea da construção de dois personagens enriquece a análise comparativa temática, pois elementos de um romance podem ser percebidos no outro e vice-versa.

\footnotetext{
${ }^{3}$ BOSI, Alfredo. "A máscara e a fenda" in BOSI, Alfredo et alli. Machado de Assis, São Paulo, Ática, 1982, p. 439. "Assim também crescia, na mesma década de 70, nos romances $A$ mão e a luva e laiá Garcia, obras de intersecção de dois lugares comuns: o do velho romantismo idealista e o do novo realismo utilitário, para o qual pendem as personagens femininas, capazes de sufocar os sentimentos do sangue em nome da "fria eleição do espírito", da "segunda natureza, tão imperiosa quanto a primeira"”.
} 
Machado de Assis não engendra a construção da trama e da heroína, Guiomar, a partir de fatos históricos específicos como o faz Stendhal. Contudo, a perspectiva histórica, sobretudo a que enfoca a situação da mulher por volta dos anos de 1850 - a narrativa se passa em 1853 - mostra ser preciosa para uma compreensão mais apurada de sua estrutura. A mão e a luva propicia ao leitor uma aguçada percepção dos costumes vigentes no Segundo Reinado, em mais de uma esfera social. Do nascimento humilde à vida adulta confortável, a trajetória de Guiomar desvenda as nuances de uma sociedade em transformação.

O tema do arrivismo no século XIX, representado nos dois romances, irá nos possibilitar observar a construção e o desenvolvimento dos protagonistas, Julien Sorel e Guiomar, em seus respectivos contextos literários e tentar estabelecer, entre as narrativas, possíveis conexões relativas às constituições das personagens, não se limitando somente ao apontamento de semelhanças tradicionalmente enfocadas nos estudos literários comparados. Os teóricos Álvaro Manuel Machado e Daniel-Henri Pageaux insistem na importância de privilegiar igualmente paralelismos e contrastes, já que um tema se comporta de forma diversa em literaturas distintas e, conseqüentemente, articula cada texto de modo específico. ${ }^{4}$ Ainda em defesa deste mesmo ponto de vista, Tania Franco Carvalhal ressalta que "a diferença deixa de ser compreendida apenas como um simples objeto a ser buscado em substituição a analogias; é mais do

\footnotetext{
${ }^{4}$ MACHADO, A. M. PAGEAUX, D-H. Da literatura comparada à teoria da literatura. Lisboa, Edições 70, 1988, p. p. 118- 121.
} 
que isso, é recurso preferencial para que se afirme a identidade nacional", de modo que a diferença permita a inserção de nossa literatura na universal. ${ }^{5}$

O assunto estudado aqui parece adequar-se melhor a uma perspectiva crítica integrada que combine o dado histórico e sua presença no texto. Se, por um lado, a ascensão social é um tema indissociável do contexto histórico, é também, no século XIX, e, não por acaso, tópico tratado frequentemente na produção ocidental. O interesse parece situar-se na confluência entre história e literatura, de forma que se possa observar a representação do mesmo em contextos distintos. Em todo texto literário a relação entre tema e estrutura da obra é fundamental encontrando-se o comparatista em posição privilegiada, porque empreende leituras simultâneas de modo a poder observar uma mesma questão em formas e contextos diversos. O teórico Yves Chevrel também aponta o caráter universal do comparativismo temático. Através deste, pode-se verificar, a partir de um corpus diversificado, um inventário de situações "universais" e o modo como elas são tratadas por diferentes tradições. ${ }^{6}$ Isso posto, vale ressaltar que os soberanos eleitos na presente análise serão sempre as próprias obras. Os métodos, sejam eles dados contextuais ou reflexão textual crítica, funcionarão somente como ferramentas utilizadas de acordo com as necessidades dos textos nos momentos em que estes se estabelecerem.

\footnotetext{
${ }^{5}$ CARVALHAL, Tania F. Literatura comparada. São Paulo, Editora Ática, 2006, p. 77. Apesar de este livro ter caráter de divulgação, ele se mostra útil, pois nos dá um panorama das diferentes correntes teóricas comparatistas de forma clara e concisa.

${ }^{6}$ CHEVREL, Yves. La littérature comparée. Paris, PUF, $5^{\text {ème }}$ édition réfondue, 2006, p. 110.
} 
No que diz respeito às relações literárias entre França e Brasil, não há o que contestar quanto à presença cultural daquele país no nosso. Mediada desde o século XVII por Portugal, a presença da cultura francesa é predominante em terras lusas e brasileiras e já há, a partir do século XVIII, traduções de Molière, Voltaire e Boileau que se ligam a preferências dos leitores. ${ }^{7}$ No século XIX, esse alcance se acentuou ainda mais com a vinda da família real para o Brasil, pois a corte afrancesada trouxe com ela hábitos determinantes, entre eles o hábito de ler romances, sobretudo os franceses. Segundo o historiador Luiz Felipe de Alencastro o estabelecimento do Segundo Império na França (1852-70) "dá ao Segundo Reinado um novo tom de modernidade e confirma 0 francesismo das elites brasileiras" ${ }^{8}$. Alencastro chama especial atenção ao Jornal das Famílias que publicava gravuras recémchegadas da França ao lado de contos de Machado de Assis de modo que combinava os daquele país à cultura local $^{9}$. Como demonstra Gilberto Pinheiro Passos, "a variada gama de contribuições francesas, no campo da literatura, filosofia, moda ou mesmo tecnologia, deixa claro que a representação do Brasil não se poderia fazer sem a inclusão de tal marca estrangeira". ${ }^{10}$

\footnotetext{
${ }^{7}$ PASSOS, Gilberto Pinheiro. O Napoleão de Botafogo: presença francesa em Quincas Borba de Machado de Assis. São Paulo, Annablume, 200, p. 26.

${ }^{8}$ ALENCASTRO, Luiz Felipe de. NOVAIS, Fernando A. História da vida privada no Brasil Vol. 2. Império: A corte e a modernidade nacional. São Paulo, Companhia das letras, 1997, 10ª reimp., p. 43.

${ }^{9}$ Idem. p. 44

${ }^{10}$ PASSOS, Gilberto Pinheiro. O Napoleão de Botafogo: presença francesa em Quincas Borba de Machado de Assis. São Paulo, Annablume, 2000, p. 11. A presença francesa nos romances de Machado de Assis tem sido meticulosamente estudada por Gilberto Pinheiro Passos. Assim tem-se agora em boa medida o largo conhecimento de tal aspecto, especialmente nos
} 
Nosso estudo, como já foi dito anteriormente, busca analisar o tema comum dos dois romances escolhidos e não terá como objetivo principal verificar a presença direta da obra stendhaliana em $A$ mão e a luva. Mesmo tendo em mente a indicação do valor literário de Stendhal que o próprio narrador de Machado de Assis nos dá em Memórias Póstumas de Brás Cubas $^{11}$, a linha condutora desta análise será a aproximação do tema de Le Rouge et Le Noir e A mão e a luva de modo que um possa revelar nuances e sugestões no outro, assim como sugere Georges Poulet neste trecho, também citado por Machado e Pageaux na obra mencionada:

La critique thématique peut révéler ce qui se transmet d'une pensée à d'autres, ce qui se découvre en diverses pensées comme étant leur principe ou leur fond commun. Alors elle tend à se confondre avec cette histoire des idées, des sentiments, des imaginations qui devrait toujours être adjacente à l'histoire dite littéraire. ${ }^{12}$

romances da chamada "segunda fase" ou "maturidade". Passos trabalha com citações, alusões e referências francesas que podem ser, em sua maioria, cotejadas e verificadas junto ao texto machadiano ampliando sensivelmente a percepção e função das mesmas nos romances. ${ }^{10}$ Esta contribuição é extremamente importante para o comparatista que se propõe estudar a França e Machado de Assis porque Ihe dá um grande panorama dessa fértil relação.

${ }^{11}$ ASSIS, Joaquim Maria Machado de. Obra completa. Tomo I. Editora Nova Aguilar: Rio de Janeiro, 1959, p. 513. "Que Stendhal confessasse haver escrito um de seus livros para cem leitores, cousa é que admira e consterna. O que não admira, nem provavelmente consternará é se este outro livro não tiver os cem leitores de Stendhal, nem cinqüenta, nem vinte, e quando muito, dez."

${ }^{12}$ POULET, Georges. Trois essais de mythologie romantique. Saint-Brieuc, Librairie José Corti, 1966, p.p. 135, 136 citado também em MACHADO, A. M. PAGEAUX, D-H. Da literatura comparada à teoria da literatura. Lisboa, Edições 70, 1988, p.119. 
Tendo em vista a natureza comparativa deste estudo, ainda de acordo com Machado e Pageaux, esse tipo de análise

obriga o investigador a empreender duas leituras simultâneas dos textos analisados: em primeiro lugar, o texto é, no plano da criação literária, um universo coerente; em segundo lugar, a procura dum sentido deve ser feita no interior do texto e também no conjunto do campo cultural a que esse texto pertence. ${ }^{13}$

Desse modo, conjugam-se uma análise da forma do texto e uma análise histórico-cultural considerando estes dois aspectos na abordagem da questão temática e suas articulações "textuais e extra-textuais". ${ }^{14}$

${ }^{13}$ MACHADO, A. M. PAGEAUX, D-H. Da literatura comparada à teoria da literatura. Lisboa: Edições 70, 1988, p.120.

${ }^{14}$ Idem, p. 120. 


\section{Capítulo I}

\section{O heroísmo deslocado na França da Restauração e a sociedade fluminense no Brasil do Segundo Reinado}

Por ser um assunto indissociável do ambiente histórico, o caráter arrivista de Julien e Guiomar é direta e respectivamente vinculado às condições sociais da França de 1830 assim como do Rio de Janeiro dos anos 1870. A situação específica em que as personagens se encontram deve ser estudada já que as possíveis possibilidades de ascensão dependem dela. Também parece ser interessante considerar o valor social da educação e do conhecimento, adquiridos formal ou informalmente, pois eles possuem peso e relevância distintos em cada país. Veremos que, em Le rouge et le noir, o conhecimento exerce função catalisadora na ascensão de Julien e em $A$ mão e a luva a educação formal de Guiomar marca sua posição desprivilegiada.

Logo no início do ensaio "Na Mansão de La Mole", ao analisar a cena em que Mlle de La Mole interessa-se pela primeira vez por Julien, Auerbach mostra que essa passagem

seria quase completamente incompreensível sem o conhecimento mais exato e detalhado da situação política, da estratificação social e das condições econômicas de um momento histórico muito definido, a saber, a França pouco 
antes da Revolução de Julho, de acordo com o subtítulo do romance (aposto pelo editor): Chronique de $1830 .^{15}$

Por mais que os acontecimentos históricos de 1789 a 1830 sejam simbólicos e muito conhecidos, é interessante ressaltar alguns aspectos fundamentais para a compreensão do pano de fundo do romance. Antes de 1789 e do Primeiro Império, a mobilidade social não era regra e uma personagem como Julien Sorel seria impensável no Ancien Régime. Tendo como fundo histórico a Restauração dos Bourbons e o reinado rígido de Charles $\mathrm{X}$, o romance já mostra um salão híbrido, no qual os nobres convivem com a burguesia enriquecida e com quem mais for preciso manter como aliado nos difíceis tempos que se anunciam. Alianças, acordos e transações são feitos por todas as partes interessadas em manter seus privilégios o que acabará por formar a mistura das classes progressiva e irreversível.

Para o historiador e crítico Arnold Hauser, os aspectos que de fato caracterizarão todo o século XIX já são inteiramente reconhecíveis por volta de $1830 .^{16} \mathrm{E}$ mesmo que a burguesia dominante neste momento seja conservadora ao ponto de adotar hábitos tipicamente aristocráticos, ela tem uma postura não-tradicionalista no modo de viver e pensar. O crítico Victor Brombert ressalta que a aceleração histórica do período é observada o tempo todo por Stendhal em seus escritos autobiográficos, sobretudo em Henry

\footnotetext{
${ }^{15}$ Op.cit., p. 406.

${ }^{16}$ Cf. HAUSER, Arnold. História social da arte e da literatura. São Paulo, Martins Fontes, 2003, p. 728.
} 
Brulard. ${ }^{17}$ Em seu artigo de dezembro de 1830, publicado no Journal de débats, Jules Janin descreve muito bem a pintura dos salões do faubourg SaintGermain feita por Stendhal ${ }^{18}$ :

Les grands seigneurs, paresseux avant tout, et regardant le travail comme le pire des maux, et d'un autre côté ayant peur des jacobins et du retour de la République de 93, s'entourent de libéraux renégats et devenus espions. Ainsi ce qu'il y a de plus nobles et de plus riche serre la main de ce qu'il y a de plus infâme et de plus pauvre. Voilà qui eût été impossible avant 1798. Ici M. de Stendhal entre dans la peinture de son époque. ${ }^{19}$

Stendhal propõe, então, uma obra que prioriza as urgências e os problemas de seu tempo e coloca, no centro dela, a trajetória do jovem filho de um carpinteiro do Franco-Condado e seus desdobramentos em diversos

\footnotetext{
${ }^{17}$ BROMBERT, Victor. Stendhal. Roman et liberté. Paris, Éditions de Fallois, 1991, p. 39 : "Derrières les remarques tranchantes et les esquisses d'une époque, il y a constatation que I'histoire s'est extraordinairement accélérée. Stendhal explique qu'un français de 1824 est un être totalement différent d'un sujet de Louis XV, qu'um homme de soixante ans a sur toutes choses des idées qui sont aux antipodes de celles de son fils de trente ans. II note à diverses reprises la coexistance de plusieurs générations très proches les unes des autres, mais séparées irrémédiablement par une éducation et des expériences totalement dissemblables. Les romans de Stendhal insisteront sur cette distance, et mettront en relief les conflits qui en résultent."
}

18 Tal ordem de fatos encontra sua primeira ressonância ficcional em Armance, primeiro romance de Stendhal publicado em 1827.

19 JANIN, Jules. «Un article sur Le rouge et le noir » in STENDHAL. Ouvres romanesques complètes. Tome I. Paris, Bibliothèque de la Pléiade, Éditions Gallimard, 2005, p.813 
estratos da sociedade francesa, às vésperas da Monarquia de Julho. São os pormenores da construção dessa trajetória um dos dois fios condutores deste estudo.

O outro conduz, naturalmente, a trajetória de Guiomar, a heroína de $A$ mão e a luva, e também a primeira personagem arrivista da obra romanesca de Machado de Assis. No Rio de Janeiro do Segundo Reinado, a instrução ainda ocupa lugar extremamente desprivilegiado, uma vez que a educação doméstica - os trabalhos manuais e a manutenção da casa - era tida como a melhor virtude feminina. Com a chegada da família real portuguesa ao Rio de Janeiro, em 1807, a dinâmica social da corte é gradativamente alterada com a inserção de novos hábitos culturais. Aos poucos, a mulher das elites dominantes começa a frequentar festas, teatros e a igreja, incrementando deste modo suas relações sociais. Os cuidados com a conversação e o aprendizado do francês tornam-se indispensáveis ao convívio nos salões; o estudo de música é cada vez mais difundido e algumas escolas para moças são estabelecidas no Rio de Janeiro a partir do Segundo Reinado. ${ }^{20}$

Temos, na obra de Machado de Assis, exemplos de personagens femininas que foram educadas em escolas. É o caso de laiá Garcia, protagonista do romance homônimo, e também de Guiomar, objeto de interesse desse estudo. Contudo, a educação formal não está no centro do objetivo almejado por essas personagens e tem função de ser um segundo

\footnotetext{
${ }^{20}$ A esse respeito ver a introdução e a primeira parte da pesquisa de BERNARDES, Maria Thereza C. C. Mulheres de ontem? Rio de Janeiro - Século XIX. São Paulo, T. A. Queiroz Editor, 1989.
} 
plano, caso o primeiro venha a falhar. O bom casamento seria a melhor opção de estabilidade e, assim, é largamente abordado nos romances escritos na segunda metade do século XIX. A pesquisadora Maria Thereza Caiuby Crescenti Bernardes faz um levantamento de vinte e cinco personagens femininas que ela denomina "jovens casadoiras", presentes em dezesseis romances urbanos retratados no Rio de Janeiro pelos principais romancistas da época. Além de Machado, Joaquim Manuel de Macedo e José de Alencar também privilegiaram o tema. ${ }^{21}$

Diferentemente da situação da jovem mulher brasileira do século XIX que frequenta a escola para ter uma forma de renda, justamente por não vislumbrar outras opções de sobrevivência, o conhecimento acadêmico é sinal de certa distinção positiva na França da Restauração. A ilustração de Julien, mesmo sendo limitada, é a arma principal de que ele dispõe em sua empreitada.

Filho do carpinteiro Sorel, Julien diferencia-se de todos os membros da família porque é o único que sabe ler. É importante atentar para o fato de que a maioria dos camponeses era analfabeta por volta de 1820 , na França. ${ }^{22}$ Mesmo com a tentativa de se estabelecer essas escolas primárias, em decorrência da

\footnotetext{
${ }^{21}$ Op. cit., p. 49.

${ }^{22}$ Além do difícil acesso à educação, ela era vista não raras vezes como inútil já que havia certa tradição de ocupação hereditária das profissões menos qualificadas. É exatamente o caso de Julien e seus irmãos na carpintaria do pai. CHARLE, Christophe. Histoire sociale de la France au XIXe siècle. Paris, Éditions du Seuil, 1991, p. 23 ."(...) l'habitat disperse et le manque de liaisons comme le sentiment répandu de l'inutilité sociale et de l'instruction élémentaire pour dês groupes voués à l'occupation héréditaire des emplois les moins qualifiés, font encore baisser les taux de scolarisation et d'alphabétisation."
} 
ordem de ensino assinada em 1816 na Restauração, foi só em 1833, com a Lei Guizot, que as comunidades com mais de quinhentos habitantes foram encorajadas a fundar as escolas primárias e de segundo grau. Estas eram destinadas a melhorar a formação geral e profissional dos alunos provenientes de famílias modestas e que não teriam acesso aos colégios e aos liceus. As escolas ainda seriam controladas e administradas, sobretudo pela Igreja Católica, por muito tempo. O ensino passaria a ser laico, obrigatório e gratuito para todos os franceses somente quase cinqüenta anos depois, com o estabelecimento da lei Jules Ferry, em 1880.

Antes de todas essas transformações, poucas crianças de classes menos favorecidas eram alfabetizadas e, se tinham esse privilégio, eram geralmente instruídas em casa ou mais comumente por padres. ${ }^{23}$ Esse foi o caso de Julien. Quando chega à casa de M. Rênal, desculpa-se junto à esposa deste por seus modos e diz: “Je n'ai jamais été au collège, j'étais trop pauvre"24. Foi primeiramente instruído por um velho parente, o cirurgião-mor, membro da Legion d'Honneur, e, após sua morte, por M. Chélan. Este lhe ensinou latim e o Novo Testamento, enquanto daquele Julien herdou seus bens mais preciosos e bases fundamentais de sua formação: as Confessions de Rousseau e o Mémorial de Sainte-Hélène de Bonaparte. Tendo se alimentado desde sua primeira juventude pelas duas obras citadas, Julien desenvolve uma

\footnotetext{
23 Para uma melhor compreensão ver MAYEUR, Françoise. Histoire générale de l'enseignement et de l'éducation en France, 1789-1930, tome 3, Perrin, 2003.

24 STENDHAL, Le rouge et le Noir in Oeuvres romanesques complètes. Tome I. Paris, Bibliothèque de la Pléiade, Éditions Gallimard, 2005, p. 375.
} 
personalidade excêntrica carregada de ilusões. A princípio tem os passos de Napoleão como guia, como indica o narrador:

Dès sa première enfance, il avait eu des moments d'exaltation. Alors il songeait avec délices qu'un jour il serait présenté aux jolies femmes de Paris, il saurait attirer leur attention par quelque action d'éclat. Pouquoi ne serait-il pas aimé de l'une d'elles, comme Bonaparte, pauvre encore, avait été aimé de la brillante Mme de Beauharnais ? Depuis bien des années, Julien ne passait peut-être pas une heure de sa vie, sans se dire que Bonaparte, lieutenant obscur et sans fortune, s'était fait le maître du monde avec son épée. ${ }^{25}$

Com bem nota Auerbach:

A natureza apaixonada e fantasiosa de Julien entusiasmou-se, desde muito jovem, pelas grandes idéias da Revolução e de Rousseau, pelos grandes acontecimentos da época napoleônica. É demasiado fantasioso, demasiado ambicioso e sequioso de domínio, para se satisfazer com uma existência medíocre no seio da burguesia $(. . .)^{26}$

Apesar das grandes reviravoltas políticas que se sucederam entre 1789 e 1830, muitos dados sociais herdados do Ancien Régime continuam presentes

\footnotetext{
${ }^{25}$ Idem, p. 370.

${ }^{26}$ AUERBACH, Erich. Mimesis. São Paulo, Perspectiva, 2002, p. 407.
} 
na primeira metade do século XIX; os princípios de hierarquia em termos de exclusão e de barreiras intransponíveis ainda são juridicamente sustentados. ${ }^{27}$

Dessa constante busca por uma posição privilegiada, Julien conclui, após visualizar o momento político em que vive, que o caminho mais seguro é fazer-se padre. Daí sua intensa dedicação ao aprendizado de latim e do Novo Testamento, o qual conhece inteiramente. A seguinte reflexão do herói é esclarecedora:

Quand Bonaparte fit parler de lui, La France avait peur d'être envahie ; le mérite militaire était nécessaire et à la mode. Aujourd'hui, on voit des prêtres, de quarante ans, avoir cent mille francs d'appointements, c'est-à-dire, trois fois autant que les fameux généraux de division de Napoléon. II leur faut des gens qui les secondent. Voilà ce juge de paix, si bonne tête, si honnête homme jusqu'ici, si vieux, qui se déshonore par crainte de déplaire à un jeune vicaire de trente ans. II faut être prêtre. ${ }^{28}$

Temos, portanto, um herói formado em grande parte pela forte influência do percurso de Napoleão em uma França restaurada e dominada, em boa medida, pela Igreja. Com a queda de imperador, perde-se a grande possibilidade de êxito através da carreira militar representada por ele. Nesse começo de século XIX, a sociedade francesa está cindida entre a nostalgia da

${ }^{27}$ CHARLE, Christophe. Histoire sociale de la France au XIXe siècle. Paris, Éditions du Seuil, 1991, p.15

${ }^{28}$ Le Rouge et le Noir, p. 370. 
grande aventura tolhida e o medo da volta da terrível experiência recentemente vivida. $^{29}$

De inspirações grandiosas, Napoleão, o exército, Paris e o poderoso clero, passamos para o pacato cotidiano do Rio de Janeiro no qual as atividades diárias narradas em nosso romance refletem um estilo de vida quase sempre prosaico.

No caso de Guiomar, temos uma contextualização da ambientação doméstica típica da sociedade patriarcal fluminense, nos anos 1850. Segundo o crítico Roberto Schwarz, a vida familiar concilia o interesse bem compreendido das duas partes - a benfeitora e a favorecida - de modo que as diferenças sociais são "sublimadas":

Agente civilizador, ou refúgio dos civilizados, é ela [a família] o critério da moralidade e da racionalidade das ações humanas, e seus desencontros - que são dificuldades, mas não problemas - formam o centro reflexivo destes livros [os romances da chamada Primeira Fase], confinados quase inteiramente ao seu círculo. ${ }^{30}$

${ }^{29}$ CHARLE, Christophe. Histoire sociale de la France au XIXe siècle. Paris, Éditions du Seuil, 1991, p. 39 "Nostalgie du rêve égalitaire chez les hommes du mouvement, nostalgie de la grandeur chez les anciens officiers, nostalgie de la jeunesse au pouvoir dans les jeunes générations bourgeoises."

${ }^{30}$ SCHWARZ, Roberto. Ao vencedor as batatas. São Paulo, Editora 34, 1997 / 5를. Ed. 2000, p. 89. 
O espaço da narrativa dificilmente extravasa a propriedade da baronesa de modo que a estrutura matriarcal é bem definida. Vivendo como uma espécie de agregada, e contando com o afeto da madrinha, a opção mais garantida de uma vida para Guiomar é o casamento. Apesar de ter frequentado a escola preparando-se para a profissão de professora primária, não é esse o destino desejado por ela. Como mostra a cientista social Heleieth Saffioti, tornar-se aluna de estabelecimentos que instruíam professoras não caracterizava como algo de prestígio:

Como as escolas normais visavam, precipuamente, à qualificação profissional de quadros para o ensino primário, destinam-se, de preferência, às camadas pouco privilegiadas pela fortuna. Estas, num país de alto índice de analfabetismo, não aspiram à instrução como veículo de ascensão social, só vindo a fazê-lo quando os efeitos da industrialização e da urbanização intensa se tornam presentes. ${ }^{31}$

A alternativa mais certa de promover a mudança de status de Guiomar está no casamento vantajoso. O envolvimento amoroso passa pelo interesse, pois o movimento calculado orienta a evolução do relacionamento. O vínculo

${ }^{31}$ SAFFIOTI, Heleieth I. B. A mulher na sociedade de classes: mito e realidade. Petrópolis, Vozes, 1979, p. 198. 
conjugal representado em $A$ mão e a luva constitui não só garantia de privilégios materiais, mas também de prestígio e reconhecimento. ${ }^{32}$

32 SCHWARZ, Roberto. Ao vencedor as batatas. São Paulo, Editora 34, 1997/ 5a Ed. 2000, p. 98 "(...) a moça - cujo ideal se resume em luzimento social, uma boa casa com bons móveis e um marido em boa posição social - contrasta vantajosamente com as paixões chorosas de Estevão, e com a inércia e Jorge, o sobrinho da baronesa, que espera sentado pelos benefícios de seu sobrenome." 


\section{Capítulo II}

\section{Os títulos}

Le rouge et le noir e $A$ mão e a luva. Antes mesmo da primeira leitura de cada romance, o leitor se depara com o título da obra e as possíveis sugestões que dele decorrem. Curiosamente, o primeiro escolhido por Stendhal foi Julien, apenas Julien. Houvesse ele permanecido, a obra teria certamente o mesmo peso, mas as indicações contidas na abertura de um dos maiores romances do século XIX podem ser valiosas. Antes mesmo de se começar a ler, o título sugere; depois ele é complementado de tal forma que passa a carregar em si grande força simbólica da obra. Logo que foi publicado em 1830, o nome Le rouge et le noir causou certa incompreensão, pois, em nenhum momento do enredo, o narrador se remete a ele de forma explícita. Um de seus primeiros leitores, Jules Janin escreve em seu artigo crítico:

M. de Stendhal, ayant eu dessein de peindre la société telle que l'avait faite le jésuitisme de la Restauration, et ne voulant pas se hasarder à intituler son ouvrage Le jésuite et le Bourgeois, par exemple, ou bien encore Les libéraux et la Congrégation, a imaginé de désigner les uns les autres par des couleurs emblématiques: de là ce titre, Le Rouge et le Noir. Seulement, j'ignore encore qui est le rouge, qui est le noir... $[\ldots]^{33}$

\footnotetext{
33 JANIN, Jules. "Un article sur Le rouge et le noir » in STENDHAL. Ouvres romanesques complètes. Tome I. Paris, Bibliothèque de la Pléiade, Éditions Gallimard, 2005, p.813
} 
Alguns anos mais tarde, por volta de 1842, surge, no periódico Le National ${ }^{34}$, uma das hipóteses mais aceitas até os dias de hoje: le rouge representaria o exército e le noir o clero. Suposição pertinente se considerarmos a narrativa e seu contexto. No entanto, não pode ser definitiva. ${ }^{35}$ Stendhal recusou todos os pedidos de explicação do título e não aludiu a ele em nenhum outro escrito, nem mesmo nas correspondências que tanto elucidaram outros aspectos de sua obra.

Para o especialista Yves Ansel, organizador da obra stendhaliana para as edições da Bibliotèque de La Pléiade, o título continua a ser um enigma e a interpretação de que le rouge simbolizaria os soldados de Napoleão não é fundamentada, pois não há indicação nenhuma da relação entre a cor e o exército mencionado. Contrariando ainda mais a crítica tradicional, o vermelho era a cor da farda de outro exército, o oponente inglês. ${ }^{36}$ Segundo Ansel, todas as possibilidades são permitidas e, ao longo dos anos, as mais diversas interpretações apareceram na enorme fortuna crítica da obra: as casas vermelhas e negras da roleta, o traje negro do herói manchado de sangue, o negro dos padres em aliança com o vermelho dos magistrados para condenar

34 Le National in Stendhal sous l'oeil de La presse contemporaine. Victor del Litto, Paris, Genève, 2001, p. p. 825, 826.

${ }^{35}$ CROUZET, Michel. Le rouge et le noir. Essai sur le romanesque stendhalien. Paris, PUF, 1995, p. 13. "Titre-énigme, titre-piège, titre-provocation, qui a fort bien réussi, car la critique, impatientée et surexcitée par l'arbitraire apparent de cette union des deux couleurs qui, loin d'orienter la lecture, lui fait barrage et cherche à l'égarer, a déversé des flots d'encre sur ce rouge et ce noir."

36 ANSEL, Yves. "Notice" in STENDHAL, Oeuvres romanesques completes. Tome I. Paris, Bibliothèque de la Pléiade, Éditions Gallimard, 2005, p. 963. 
Julien e inúmeras outras. ${ }^{37}$ Estamos diante, então, de um título sugestivo e que, incluindo todas as possibilidades interpretativas, nos remete ao universo da ficção propriamente dita. Mesmo sendo mais hermético que Lucien Lewen, por exemplo, Le rouge et le noir é composto e anuncia o caráter ficcional da obra, chamando também a atenção para a natureza artística a ela inerente.

Contudo, há um subtítulo não menos importante e que aponta aspectos complementares àquele. Deparamo-nos em seguida com: Chronique de 1830 e, imediatamente, temos uma mudança no tipo de registro literário. Chronique é um termo greco-latino proveniente de chronica, cuja etimologia remete a dois conceitos: de 'narração histórica, feita por ordem cronológica' e 'seção ou coluna de jornal ou de revista, que trata de assuntos da atualidade'. ${ }^{38}$ Ora, o registro agora indica uma posição que se refere à esfera histórica, factual de um momento preciso. O texto pertence a um universo específico e este mundo de 1830 é inseparável dos fatos que se sucederam desde 1789. Stendhal mostrou ser precocemente lúcido em relação às enormes transformações que transtornaram a França e estabeleceram uma nova ordem em todas as esferas sociais. Instituições, vida política e critérios artísticos tiveram desmoronados seus alicerces para serem reconstruídos sobre valores impostos pelas demandas de um grupo dominante emergente. Não é possível pensar no ano de 1830 sem pensar nas Journées de Juillet e seus desdobramentos. ${ }^{39}$

\footnotetext{
${ }^{37}$ Idem, p. 964.

${ }^{38}$ CUNHA, Antônio Geraldo da Cunha. Dicionário Etimológico Nova Fronteira. Rio de Janeiro, Editora Nova Fronteira, 1982, p. 230.

39 Jornadas revolucionárias de Paris contra o rei Carlos X, que levou Luís Filipe ao trono. A Monarquia de Julho é um período de proeminência da alta burguesia, que substitui o direito
} 
Também não se deve ignorar a sensível mudança observada no modo de se escreverem romances desde Stendhal e Balzac. As obras desses dois autores são construídas a partir de tal matéria, dando início a um tipo de texto original que incorpora em si os anseios complexos e contraditórios de um povo, em plena fase de adaptação às recentes transformações. As novas possibilidades surgidas das mudanças marcam o início do modo de se viver e de se fazer arte hoje conhecido por moderno. Então, ao ler Le rouge et le noir Chronique de 1830, temos um registro ambivalente com duas orientações a serem seguidas. A de um discurso ficcional, romanesco e de outro histórico com tempo e contexto precisamente delimitados. Contudo, a história de Julien Sorel poderia perfeitamente figurar em qualquer periódico parisiense às vésperas de Julho de 1830, assim como figurou o "Procès Berthet", caso verídico que teria servido de inspiração para Stendhal na concepção de seu herói. ${ }^{40} \mathrm{O}$ crítico, portanto, tem em mãos uma obra complexa e múltipla que incorpora em si questões fundamentais que marcariam todo o século XIX.

Tentar compreender as sugestões do título da outra obra aqui em questão é tarefa menos intricada. A mão e a luva é um romance de dimensões quase inversamente opostas àquelas de Le rouge et le noir. Enxuto e conciso,

divino dos monarcas. Também é importante porque a frança é dotada, neste momento, de uma constituição mais liberal, chamada a Carta de 1830.

40 Fait divers, ocorrido em 1827. O jovem ambicioso Antoine Berthet assassina com dois tiros Madame Michoud em cuja casa morou, na ocasião em que foi preceptor de um de seus filhos. Recusado pelo seminário de Grenoble, Berthet suspeita que a rejeição tenha sido conseqüência de cartas depreciativas enviadas pela senhora mencionada. A esse respeito ver o artigo publicado na Gazette dês tribunaux e reproduzido em STENDHAL, Oeuvres romanesques complètes. Tome I. Paris, Bibliothèque de la Pléiade, Éditions Gallimard, 2005, p.p. 809 - 811 . 
esse segundo romance de Machado de Assis acomoda em si um enredo relativamente simples, produzindo uma atmosfera quase leve se comparada ao livro francês. Para o crítico Roberto Schwarz, "não há reticência na imagemtítulo $A$ mão e a luva", ${ }^{41}$ ou seja, quase todo seu sentido já está dado até mesmo porque explicitado pelo último capítulo.

Ambientado em um momento tranquilo do Segundo Reinado, a narrativa tem como principal objetivo acompanhar de perto a construção de sua heroína e os desdobramentos de seu percurso na história. Aqui não se encontram grandes homens políticos nem representantes de instituições importantes; os acontecimentos se desenrolam no interior da vida privada e afetam personagens prosaicas que figuram no contexto da sociedade carioca à época. Apesar de o narrador referir-se ao título somente no último parágrafo do último capítulo, ele está implícito em toda sua constituição. A interpretação primeira e mais evidente é de uma combinação perfeita entre dois elementos: a mão que se ajusta perfeitamente à luva. À primeira vista, A mão e a luva parece ser um título quase banal, simplório, mas já na leitura inicial incorpora questões mais relevantes.

Mais do que representar apenas a combinação perfeita entre Guiomar e seu pretendente, Luís Alves, ilustra as diversas etapas do desenvolvimento da protagonista. Parece haver o tempo todo um encaixe perfeito de Guiomar e seu destino, adaptando-se ela perfeitamente à escola na ocasião da morte da mãe. Em seguida, já na casa da madrinha, comporta-se como se sempre tivesse aí habitado; a sua acomodação não poderia ter sido mais suave. E, por fim, ocupa

\footnotetext{
${ }^{41}$ Op. cit., p. 114.
} 
soberana a posição de esposa elegante e reconhecida pela realização de um belo casamento. O título $A$ mão e a luva alude, portanto, a uma seqüência de desdobramentos que resultam quase sempre em uma situação favorável ao objetivo central de Guiomar.

As escolhas dos títulos, sobretudo a do romance francês, funcionam como guias iniciais na leitura das obras, indicando e sugerindo variadas linhas de investigação. Pode-se dizer também que há uma oposição em Le rouge et le noir e uma complementaridade em $A$ mão e a luva. Não por acaso, essas características parecem permear respectivamente as duas narrativas. Mostram-se, deste modo, importantes pontos de partida de uma análise que se pretende detalhada. 


\section{Capítulo III}

\section{Variação e unidade: os ambientes de Julien e Guiomar}

Situadas em espaços muito distintos, as narrativas de Le rouge et le noir e $A$ mão e a luva têm seus desenvolvimentos estruturados de forma indissociável de seus ambientes. O que o primeiro tem de múltiplo e grandioso, o segundo tem de unificado e modesto. Enquanto Stendhal amplia e diversifica sua história em locais variados com desfecho em Paris, cidade mais importante do século XIX, nas palavras de Walter Benjamin, Machado de Assis concentra a sua no Rio de Janeiro, mais específica e diminutivamente em uma casa com chácara. Tentaremos, a princípio, examinar o espaço mais amplo e complexo do romance francês para, em seguida, contrapor-lhe a opção particular do brasileiro e suas possíveis implicações.

Pode-se dizer que Le rouge et le noir é um romance dividido em três espaços principais: Verrières, Besançon e Paris como aponta Victor Brombert:

Le monde de Verrières, ceux du séminaire de Besançon et la société ultra de Paris, sont présentés en des termes qui rappellent les pages les plus caustiques de ses articles envoyés aux revues anglaises. Les portraits tendent parfois à la caricature. Stendhal prend toutefois très au sérieux les conditions sociales et politiques telle qu'il les observe: le fossé grandissant entre les générations, les réactions néfastes d'un clergé apeuré et d'une noblesse dépassée par l'histoire, les 
effets suffocants Du conformisme, le despotisme même de l'histoire. ${ }^{42}$

O título do primeiro capítulo de Le rouge et le noir, "Une petite ville" indica que o romance começa com a narração de seu espaço inicial, ou seja, a descrição de Verrières. No segundo parágrafo do capítulo e também do romance, o narrador já antecipa a estrutura social do local no qual se passa a primeira fase da narrativa:

(...) Un torrent, qui se précipite de la montagne, traverse Verrières avant de se jeter dans le Doubs, et donne le mouvement à un grand nombres de scies à bois, c'est une industrie fort simple et qui procure un certain bien-être à la majeure partie de habitants plus paysans que bourgeois. Ce ne sont pas cependant les scies à bois qui ont enrichi cette petite ville. C'est à la fabrique de toiles peintes, dites de Mulhouse, que l'on doit l'aisance générale qui, depuis la chute de Napoléon, a fait rebâtir les façades de presques toutes maisons de Verrières ${ }^{43}$

Essa passagem mostra a clara divisão social da cidade - plus paysans que bourgeois - e antecipa o grupo do qual Julien Sorel fará parte, ou seja, o

\footnotetext{
${ }^{42}$ Op. cit., p. 59.

${ }^{43}$ Le Rouge et le Noir, p.351.
} 
de camponeses que vive da extração de madeira e constitui a maior parte dos habitantes de Verrières. Na sequência, a apresentação da grande fábrica de parafusos pertencente ao prefeito da cidade, Monsieur de Rênal, e a descrição deste e de sua casa ilustram a atmosfera de certa tensão social resumida pelo narrador : "Cette vue [a vista da casa do prefeito] fait oublier au voyageur l'atmosphère empestée des petits intérêts d'argent dont il commence à être asphyxié."44

As três próximas figuras apresentadas vêm completar o círculo principal de personagens desse espaço. Monsieur Chélan, o abade da cidade, a honesta Madame de Rênal e o grosseiro diretor do abrigo de pobres e rival de Monsieur de Rênal, Monsieur de Valenod.

O abade Chélan é o primeiro protetor de Julien e é através dele que Julien é contratado como preceptor das crianças de Rênal. Depois do cirurgiãomor, a educação de Julien foi aperfeiçoada por Chélan. A transferência de Julien de Verrières para o seminário de Besançon também será intermediada pelo abade. Veremos mais à frente que outra mudança de Julien, do seminário para Paris, também ocorrerá sob tutela de um membro do clero, o abade Pirard. As variações de ambientes, tanto de Verrières para o seminário e deste para Paris, são propiciadas pela igreja. Isso indica o grau de importância e influência que o clero possui nesse momento, tanto na província quanto em Paris.

${ }^{44}$ Le Rouge et le Noir, p. 352. 
Madame de Rênal, a ingênua esposa do prefeito, representa as primeiras experiências de Julien em aspectos diversos. Ele vivencia o contato com outra classe, a burguesia com poder regional; relaciona-se totalmente com uma mulher; e tem também sua primeira possibilidade de manter moralmente a ascensão social conseguida através do posto de preceptor de seus filhos. Tal relacionamento representa, de certo modo, a primeira fase de maturação nos modos sociais do herói. A esposa do prefeito é a amante e educadora dessa primeira etapa, assim como Mathilde de La Mole o será na segunda. De acordo com Michel Guérin, as personagens femininas são fundamentais no processo de ascensão que se dá no romance:

Pertinente par le corps et le caprice (cette volonté hors règles), la (jolie) femme, à condition aussi qu'elle gouverne la société em joignant la réputation sociale de son mari à celle, aimable, que lui fait son amant, est éducatrice; elle aporte les manières et les moyens, elle seule ("ce que femme veut") peut sanctifier l'effraction, abolir d'un mot ou d'une mine le péché social originel. ${ }^{45}$

Ainda no que se refere à questão relacionada ao espaço e ao envolvimento amoroso, o fato de Madame de Rênal ter sido educada na província - mais precisamente em um convento - influencia na postura que ela terá frente ao caso com o jovem preceptor. Mais de uma vez o narrador ${ }^{45}$ GUÉRIN, Michel. La grande dispute. Essai sur l'ambition, Stendhal et le XIXe siècle. Actes sud, 2006, p. 27. 
ressalta que ela não conhece o hábito de ler romances e isso a diferencia das parisienses, pois estas têm um modelo a ser mimetizado. ${ }^{46}$ Essa será uma das principais diferenças na abordagem do amor nos dois espaços.

A figura que fecha o círculo provincial é Monsieur de Valenod:

M. Valenod était ce qu'on appelle, à cent lieues de Paris, un faraud; c'est une espèce d'un naturel effronté et grossier. Son existence triomphante, depuis 1815, avait renforcé ses belles dispositions. (...) M. Valenod avait dit en quelque sorte aux épiciers du pays : "Donnez-moi les deux plus sots d'entre vous"; aux gens de la loi: "Indiquez-moi les deux plus ignares"; aux officiers de santé: "Designez-moi les deux plus charlatans." Quand II avait eu rassemblé les plus effrontés de chaque métier, II leur avait dit: "Régnons ensemble. ${ }^{47}$

Proveniente da pequena burguesia sem titulação, esse político enriquecido à custa do dinheiro destinado aos pobres ilustra um tipo de personagem curioso que, mesmo não pertencendo a nenhum setor da nobreza, apoia sua política e suas figuras influentes para obter vantagens, benefícios e posições políticas. Característico das pequenas cidades, representa as

\footnotetext{
${ }^{46}$ Le rouge et le noir, p. 383. "À Paris, la position de Julien envers Mme de Rênal eût bien été vite simplifiée; mais à Paris, l'amour est fils des romans. Le jeune précepteur et sa timide maîtresse auraient retrouvé dans trois ou quatre romans et jusque dans les couplets du Gymnase, l'éclaircissement de leur position. Les romans leur auraient tracé le role à jouer, montré le modele à imiter; et ce modele, tôt ou tard, et quoique sans nul plaisir, et peut-être en rechignant, la vanité eût forcé Julien à le suivre."

${ }^{47}$ Le rouge et le noir, p. 480.
} 
contradições decorrentes da Restauração. A rivalidade entre Monsieur de Rênal e Monsieur de Valenod leva este a desmoralizar o prefeito e a acusar sua esposa de adúltera através de uma carta anônima. Pode-se dizer que, além da função de exemplificar certo tipo social da época, Valenod também é responsável indireto pela transferência de Julien para o seminário, que servirá de ponte entre Verrières e Paris.

Entre a província e Paris, há um intervalo temporal e espacial no seminário em Besançon. Período significativo por mostrar a função política da igreja e a inadequação de Julien naquela função, essa será uma etapa de grande aprendizagem. ${ }^{48}$ Desencantado com o perfil dos seus companheiros seminaristas, que são superficiais e só pensam em conseguir qualquer pequena posição que Ihes for oferecida, Julien assegura-se de que está deslocado naquele recinto. Os acontecimentos que se seguem, sobretudo a proximidade entre o abade Pirard e o Marquês de La Mole, indicam que a próxima etapa de Julien será na capital.

A primeira cena em que o abade Pirard aparece é significativa, porque recebe uma carta do Monsieur de La Mole; temos a antecipação da transferência que se dará na segunda parte da narrativa. O abade Pirard é o vínculo que liga um espaço a outro, Verrières e Paris. Além de ele próprio transitar nos dois mundos, será o responsável pela mudança de Julien. Espécie

\footnotetext{
${ }^{48}$ REY, Pierre-Louis. Le rouge et le noir- Stendhal. Paris, Ellipses, 2002, p. 22. "Le séminaire apprend à Julien jusqu'où peuvent aller la veulerie et le mensonge. Le devoir d'hypocrisie, qu'il s'est tracé dès son entrée dans la vie, trouve ainsi son plein champ d'exercice."
} 
de seu mentor e protetor, Monsieur Pirard é a única outra personagem além daquela que habitará os dois ambientes mencionados.

O próximo grande ambiente retratado no romance é Paris. Assim como nos romances de Balzac que logo seriam publicados, Le père Goriot e Illusions perdues, a capital é sempre o objetivo final na trajetória dos arrivistas. É onde a vida política e cultural acontece de fato e há o maior reconhecimento dos que alcançam uma posição privilegiada. Contratado como secretário de um grande nobre e proprietário, Julien tem a oportunidade de circular pelos salões mais relevantes da França. Eficiente e aparentemente leal ao seu chefe, ganha a confiança do Marquês de La Mole e a possibilidade de transitar nos meios políticos conservadores de maior influência na Restauração, chamados ultras. A mudança de ambiente resulta consequentemente em alterações nas ações, nas personagens, nas intrigas e, na mais importante delas, no envolvimento amoroso.

Instalado no Hôtel de La Mole, Julien encontra-se imerso em um universo completamente novo, onde tem iníco a segunda fase da narrativa. A adaptação acontece de forma gradativa e, aos poucos, ele apreende o modo de funcionamento dessa classe. ${ }^{49}$ Ainda traumatizada com a Revolução e o Império, a nobreza vive um momento de extrema contenção, sendo reuniões e jantares marcados pelo tédio sentido pelos mais perspicazes. A palavra ennui e seus derivados (ennyué, ennuyée) aparecem com frequência a partir do

\footnotetext{
${ }^{49}$ REY, Pierre-Louis. Le rouge et le noir- Stendhal. Paris, Ellipses, 2002, p. 21. "Julien doit aussi apprendre le fonctionnement de la société de la Restauration, les différences entre la province et Paris, les nuances grace auxquelles les classes marquent des distances entre elles."
} 
segundo tomo do romance, ou seja, no momento da transferência de Julien para Paris. Ele logo é acometido por esse tipo de aborrecimento, já que nesse meio não há lugar para nenhuma descontração; aí está uma das diferenças entre a sociedade nobre e a burguesa:

La politique dirigeante qui fait l'entretien des maisons bourgeoises n'est abordée dans celles de la classe du marquis, que dans les instants de détresse. Tel est encore, même dans ce siècle ennuyé, l'empire de la necessité de s'amuser, que même les jours de dîner, à peine que le marquis avait-il quitté le salon, que tout le monde s'enfuyait. Pourvu qu'on ne plaisantât ni de Dieux, ni des prêtres, ni du roi, ni des gens em place, ni des artistes protegés par la cour, ni de tout ce qui est établi; pourvu qu'on ne dit bien ni de Béranger, ni des journaux de l'opposition, ni de Voltaire, ni de Rousseau, ni de tout de ce qui permet un peu de franc-parler; pourvu surtout qu'on ne parlât jamais politique, on pouvait librement raisonner de tout. ${ }^{50}$

Como é possível notar na passagem acima, havia um grande sentimento de que a liberdade de se expressar era absolutamente tolhida. A passagem acima remete ao monólogo de Figaro na peça Le mariage de Figaro (1782) de Beaumarchais, no qual a personagem reflete sobre a inutilidade do jornal em que escreve - Figaro o chama de Journal inutile. ${ }^{51} \mathrm{~A}$ ironia aqui ganha grande

\footnotetext{
${ }^{50}$ Le rouge et le noir, p. 576.

${ }^{51}$ BEAUMARCHAIS. Le mariage de Figaro / Le Barbier de Séville. Paris, Classiques Français, 1995, p. 138. "Las de nourrir un obscur pensionnaire, on me met un jour dans la rue; et comme il faut diner, quoiqu'on ne soit plus en prison, je taille encore ma plume, et demande à chacun
} 
amplitude, pois, além de tratar da censura presente em dois séculos, o XVIII e o XIX, coloca lado a lado duas grandes figuras populares e as questões de dois períodos históricos díspares. É interessante observar que tanto Figaro quanto Julien são personagens que querem encotrar um lugar ao sol. Le rouge et le noir é comumente tido como um romance sério, sisudo e pesado; no entanto, ele oferece muitos momentos de humor ao leitor atento. Esse artifício de contrastar o que é grave e o que é irônico pode ser percebido tanto no discurso do narrador como no de Julien inúmeras vezes, no decorrer do romance. O trecho acima é interessante, porque nos transmite com clareza a atmosfera dessas soirées.

Nenhum comentário contra o regime estabelecido e tudo o que se relaciona a ele é permitido, de modo que quase todos os assuntos interessantes são interditos. A frase que termina a passagem não poderia ser mais ferina: desde que não se fale de nenhum assunto que tenha alguma relevância, pode-se tratar de tudo.

Julien transita por espaços diferentes e pode-se dizer que a evolução gradativa de sua carreira é intimamente ligada ao local em que se situa nos diversos momentos. As carreiras de preceptor, seminarista e secretário/ oficial correspondem respectivamente a Verrières, Besançon e a Mansão de La Mole.

de quoi il est question: on me dit que, pendant ma rétraite économique, il s'est établi en Madrid un système de liberté sur la vente des productions, qui s'étend même à celles de la presse; et que, pourvu que je ne parle en mes écrits ni de l'autorité, ni du culte, ni de la politique, ni de la morale, ni des gens en place, ni des corps en crédit, ni de l'Opéra, ni des autres spectacles, ni de personne qui tienne à quelque chose, je puis tout imprimer librement, sous l'inspection de deux ou trois censeurs. Pour profiter de cette douce liberté, j'annonce un écrit périodique, et, croyant n'aller sur les brisées d'aucun autre, je le nomme Journal inutile." 
Para o crítico Jacque Dubois, esse procedimento é recorrente na obra de Stendhal e permite a construção da progressão do herói. Além disso, a divisão do romance em diversas fases propicia a renovação de personagens e o contraste entre os vários tempos e lugares. ${ }^{52}$

A mudança de espaço é ascensional. Primeiro a alta burguesia "enobrecida", depois o clero representado pela influência do abade Pirard e, por fim, a Mansão de La Mole. Paris é o cume, tal como para Napoleão; na capital, a casa do Marquês é o ápice da vida social.

Passando agora para a questão dos ambientes em $A$ mão e a luva, deparamo-nos com um quadro muito diverso do que vimos em Le rouge et le noir. Aqui, a multiplicidade e a amplitude encontradas no romance francês não podem ser verificadas. Ao contrário, é possível dizer que restrição e unidade são os principais traços relativos ao espaço. A trama se concentra na mansão da baronesa, a madrinha de Guiomar. E ali é onde a narrativa se inicia, desenvolve-se e tem seu desfecho.

A personagem que abre $A$ mão e a luva é Estevão e, será no seu reencontro com Guiomar, em uma das primeiras cenas do terceiro capítulo, que teremos certa noção da dimensão da chácara da casa:

A chácara não era em demasia grande; e por mais lento que fosse o passo da madrugadora [Guiomar], não gastaria ela

\footnotetext{
52 DUBOIS. Jacques. Stendhal / Une sociologie romanesque. Paris, Éditions la découverte, 2007, p. 26.
} 
imenso tempo em percorrer até o fim aquela porção da rua em que entrara. $^{53}$

A chácara é praticamente o único espaço pelo qual Guiomar circula. Algumas das únicas exceções são as idas ao teatro com a madrinha e Jorge, sobrinho da baronesa. No entanto, o ambiente mencionado é suficiente como símbolo para o arrivismo da personagem, pois representa o patrimônio que pode vir a lhe pertencer. Segundo Roberto Schwarz, o conflito central dos romances da primeira fase machadiana é estreito e concentrado na esfera doméstica e aí se dão os conflitos sociais e suas resoluções. Esse procedimento seria empregado para marcar o provincianismo latente característico da sociedade brasileira àquela época. ${ }^{54}$ As ações se passam na propriedade na qual vive Guiomar e suas contiguidades. Na mesma cena tomamos conhecimento de que o jardim da casa de Luís Alves era separado apenas por uma cerca da chácara da baronesa:

O jardim ficava nos fundos da casa; era separado da casa da vizinha por uma cerca. Relanceando os olhos pela chácara, viu Estêvão que era plantada com esmero e arte, assaz vasta, recortada por muitas ruas curvas e duas grandes ruas retas. Uma destas começava das escadas de pedra da casa e ia até o fim da chácara; a outra ia da cerca de Luís Alves até a extremidade oposta, cortando a primeira no centro.

\footnotetext{
${ }^{53}$ A mão e a luva, p. 208.

${ }^{54}$ Op. cit, p. p. $85,86$.
} 
Do lugar que ficava Estêvão só a segunda rua podia ser vista de ponta a ponta. ${ }^{55}$

No trecho acima, tomamos conhecimento da configuração espacial na qual a narrativa se desenvolve. Tal proximidade faz com que o contato entre as duas residências seja praticamente inevitável. Tal disposição seria outro anúncio presumível da relação posterior entre Guiomar e o dono da casa vizinha. Apesar de a primeira abordagem ser de Estêvão e não de Luís Alves, a aproximação física se dá a partir do território deste. Estêvão está em local alheio desde o início e Luís Alves está em sua casa. A vulnerabilidade da divisão dos espaços também é uma indicação de que um poderá ser a extensão do outro e vice-versa, o que efetivamente irá se concretizar. Por fim, podemos concluir que as duas moradas estão em níveis sociais e econômicos não inteiramente díspares. Ficam separadas por uma cerca e não por um muro como acontece com a casa humilde da infância de Guiomar em que ela observa as moças ricas através de uma fenda. ${ }^{56}$ No caso da menina Guiomar, ainda pobre, há apenas uma possibilidade pequena de transição de um mundo para o outro. Já acomodada na casa elegante da madrinha, o trânsito de um espaço ao outro não só se torna possível, como será o mais provável com o avanço da história.

\footnotetext{
${ }^{55}$ A mão e a luva, p. 207.

${ }^{56}$ Sobre a questão da fenda, o ensaio já mencionado de Alfredo Bosi analisa a questão mais de perto.
} 
No quarto capítulo, a ação é interiorizada e redimensionada a um ambiente menor ainda, numa espécie de gradação invertida em relação à passagem do terceiro capítulo. Dos jardins, parte mais ampla da chácara, passamos ao interior da casa, mais precisamente a uma saleta na qual o convívio entre as personagens não poderia ser mais familiar, como mostra o narrador num tom bem-humorado:

Guiomar chegou daí a pouco e achou-os na "saleta de trabalho", eufemismo elegante, que queria dizer literalmente sala de conversação entremeada de crochet. Mrs. Oswald vinha com ela; ambas riam alegremente de não sei que episódio visto no caminho. Jorge erguera-se, pausado mas risonho, apertou a mão de Guiomar, - apertou-a deveras, mais do que era usual e cortês. Guiomar não pareceu afligir-se; perguntou-lhe pela saúde, transmitiu à madrinha as lembranças que Ihe mandavam e dispôs-se a sair. ${ }^{57}$

Tudo aqui nos remete ao intimismo. A "saleta", por ser um espaço pequeno, aproxima física e psicologicamente as personagens; Guiomar e Mrs. Oswald aparecem em total clima de descontração; a interação entre Jorge e Guiomar, apesar da investida daquele, é natural, visto que os assuntos de Guiomar são absolutamente corriqueiros. O contraste dessa cena com as da Mansão de La Mole é evidente. Julien participa de jantares em que a

${ }^{57}$ Idem, p. 231. 
frequência é, em sua maioria, composta de nobres influentes, como mostra o seguinte fragmento:

Julien observa que la conversation était ordinairement maintenue vivante par deux vicomtes et cinq barons que $\mathrm{M}$. de La Mole avait connus dans l'émigration. Ces messieurs jouissaient de six à huit mille livres de rente; quatre tenaient pour La Quotidienne, et trois pour la Gazette de France. L'un d'eux avait tous les jours à raconter quelque anecdote du Château ou le mot admirable n'était pas épargné. Julien remarqua qu'il avait cinq croix, les autres n'en avaient en général que trois. ${ }^{58}$

A diferença de registro é evidente, quando comparamos os dois trechos. O romance brasileiro se caracteriza por dimensões restritas, enquanto o francês o é por dimensões ampliadas. Neste transitam viscondes e barões com diversos títulos com voz ativa em periódicos relevantes da Restauração; assim como o Marquês de La Mole, são emigrados restituídos e usufruem livremente, naquele momento, de suas rendas. Stendhal trata dos acontecimentos históricos turbulentos desde a Revolução, eventos que influenciam diretamente os franceses de todas as classes sociais. A progressão de Julien no romance é sinalizada por ambientes que representam os grupos dominantes do país naquele momento: a alta burguesia, o clero e, por fim, a nobreza. Já Machado de Assis foca um microcosmo, no qual os conflitos só dizem respeito a ele

\footnotetext{
${ }^{58}$ Le rouge et le noir, p.p. $576,577$.
} 
mesmo. Roberto Schwarz atribui essa ocorrência à tendência do escritor brasileiro de utilizar a família como paradigma da sociedade; essa fórmula funcionaria porque iria perfeitamente ao encontro das tradições católicas e patriarcais estabelecidas no Brasil. ${ }^{59}$

Observamos, portanto, as diferenças entre as duas esferas no que diz respeito à natureza das ações de Julien e Guiomar. Enquanto aquele precisa obter suas conquistas em cada um dos meios em que se encontra, esta deve alcançar seus objetivos através de um acordo interno com o círculo familiar. A narrativa francesa é localizada no país em que transformações importantes influenciam não só o modo de vida fundamental dessa nação, como também de outras. Seus acontecimentos têm eco em todo o mundo ocidental, sobretudo nos países monarquistas europeus nos primeiros tempos de revoluções. ${ }^{60}$ No caso de nosso romance, temos um país em momento de grande estabilidade no apogeu do Segundo Reinado - o imperador Dom Pedro II só cairia após quase trinta anos do período em que se passa $A$ mão e a luva - em um Rio de Janeiro com uma população menor que trezentos mil habitantes. A lição de José Alencar, na qual o tamanho restrito e a contenção do espaço eram não defeitos, mas uma adequação ao "tamanho da sociedade fluminense" ${ }^{61}$, exarada em 1875, já encontrava em Machado, no ano de 1874, um exemplo importante, sobretudo porque, desse modo, nosso autor poderia

\footnotetext{
${ }^{59}$ Op. cit, p. 84.

${ }^{60}$ A mais relevante é a grande preocupação do Reino Unido com as grandes reviravoltas na organização política francesa nos últimos cinquenta anos.

${ }^{61}$ ALENCAR, José de. "Carta posfácio à Senhora" in Senhora / Iracema. São Paulo, Editora Scipione, 1994, p. 186.
} 
se debruçar, de forma precisa e contundente, sobre as motivações e interesses existentes no seio das famílias.

Por outro lado, a concentração espacial não deixa - conforme notamos de refletir em ponto pequeno a dimensão mesma da sociedade brasileira, em que compadrio, pouca possibilidade de ascensão e "arranjos" domésticos constituem certa tônica da convivência entre seus grupos constituintes. 


\section{Capítulo IV}

\section{Masculino / Feminino}

Uma das primeiras questões que se colocam quando estudamos comparativamente Le rouge et le noir e A mão e a luva é a do sexo. A escolha de construir determinadas personagens, masculinas ou femininas, depende da gênese de cada narrativa ou, até mesmo, da arbitrariedade de seu criador. No entanto, é nossa tarefa tentar compreender essa opção e seus desdobramentos.

Quando Stendhal parte para a escritura de um romance como Le rouge et le noir, que tem pretensões de abarcar uma grande diversidade de meios e situações, a escolha de um protagonista masculino inspirado, em parte, na sua experiência pessoal mostra que Julien Sorel representa determinado grupo de jovens em um momento demarcado da história francesa. Nas palavras do crítico stendhaliano Michel Crouzet, Julien é:

le délégué de la jeunesse de province à la conquête de Paris, de toute jeunesse à la conquête du monde, des places, des femmes, du pouvoir, bref, le héros de l'égalité démocratique. Julien, fils du peuple, ennemi des nobles, des prêtres, des riches, proche des conspirateurs, "jacobin" d'intention et d'affinités, est un personnage de $1830 .^{62}$

${ }^{62}$ Op. cit., p. 111. 
Le rouge et le noir é uma obra de dimensões largas em muitos sentidos. Como vimos no capítulo anterior, os espaços são variados geográfica e socialmente, as personagens e as classes que representam são diversificadas e vários são os assuntos tratados, de política às relações amorosas. A trajetória percorrida por Julien é, de certa forma, emblemática de um novo modo de vida que, mesmo ainda improvável, foi possibilitado pelas recentes reviravoltas políticas.$^{63} \mathrm{As}$ carreiras de maior prestígio, as mesmas ambicionadas por Julien, são estritamente ligadas ao homem. Uma figura masculina poderia simbolizar, de modo mais consentâneo, toda essa abrangência na primeira metade do século XIX. Contudo, tratando-se desse romance, não podemos nos conter nas generalizações, pois temos em mãos uma narrativa de caráter único. É na conjunção do contexto geral com a especificidade artística que reside sua força. Algumas particularidades merecem ser vistas mais de perto porque anunciam e explicam as variadas etapas da constituição da figura francesa em questão.

Julien, o mais novo dos três filhos de Sorel, representa o inverso do conformismo dos irmãos com a vida camponesa. Das feições físicas às psicológicas, o narrador ressalta repetidamente o contraste existente entre Julien e seus próximos. Magro e franzino, portador de certa cultura e, por isso, desajustado no meio em que vive, Julien é quase um estrangeiro no seio da

${ }^{63}$ GUÉRIN, Michel. La grande dispute. Essai sur l'ambition, Stendhal et le XIXe siècle. Actes sud, 2006, p. 37. "Le XVIIle siècle avait répudié l'extravagance et donné la parole au moi pour ramener les aventures à une taille et à un sens humains; le siècle suivant, au moins dans sa première partie, découvre le réalisme de l'imagination et l'appelle ambition. C'est un rêve éveillé, un conte plausible - un conditionnel plus qu'un fantasme. La sublimation (l'élevation) transforme effectivement la matière brute des choses et des gens." 
família. Inadequado ao trabalho na carpintaria, mostra, desde a infância, inclinação para outras atividades, sendo a primeira delas o exército. O narrador insiste nesse desajuste por diversas vezes, sobretudo no primeiro terço do romance. A expressão "dès sa première enfance" inicia alguns fragmentos nos quais a inadequação do herói é sempre ressaltada. A passagem mais exemplar neste sentido parece ser a que mostra um quase devaneio de Julien na infância - o narrador usa a expressão "fou"- e proclama seus futuros empreendimentos:

Dès sa première enfance, la vue de certains dragons du 6e, aux longs manteaux blancs, et la tête couverte de casques aux longs crins noirs, qui revenaient d'Italie, et que Julien vit attacher leur chevaux à la fenêtre grillée de la maison de son père, le rendit fou de l'état militaire. ${ }^{64}$

Desde a «primeira infância », o espírito de Julien pende para uma existência maior do que a reservada junto à sua família. Fomentada pelas incríveis anedotas contadas pelo cirurgião-mor - "Plus tard, il écoutait avec transport les récits de batailles du pont de Lodi, d'Arcole, de Rivoli [...]"65 -, sua imaginação viajava pelos campos de batalha conferindo certa magia àquele universo. O encantamento do herói ultrapassava a função elementar dos oficiais. O êxtase parece estar contido mais na representação da função, ou

\footnotetext{
${ }^{64}$ Le rouge et le noir, p. 369.

${ }^{65}$ Idem. p. 369.
} 
seja, no prestígio, nas vestimentas dos homens e dos cavalos, do que nas tarefas propriamente ditas. Michel Crouzet sugere que a ambição em si mesma seja a grande paixão de Julien:

Et l'ambition de Julien est rarement définie comme l'ambition de quelque chose, elle n'as pas de fin, elle ne repose pas sur un calcul en vue d'une fin; certes, l'Église semble promettre la fortune; mais dénuée d'objectif précis, son ambition est de "faire fortune", "une fortune colossale", et indéterminée, ou se mêlent des rêves de pouvoir, de gloire, d'héroisme, de supériorité absolue, de "reconnaissance" qui compenserait une humiliation native; elle tend à être une sorte de montée gratuite, pour se prouver, pour gagner sa propre estime. $^{66}$

Passemos, agora, à figura feminina que anuncia o romance machadiano e tentemos individualizá-la. A tendência a um estilo de vida diferente de suas origens também aparecem na primeira infância de Guiomar. Em $A$ mão e a luva, há um trecho que tem função parecida ao dos militares montados a cavalo mencionado acima. Guiomar, também desde cedo, é profundamente tocada pelos signos que simbolizam o prestígio. Aos olhos da criança, os tecidos nobres, as jóias e o comportamento altivo, ganham uma dimensão quase mística do que seria a existência na conjuntura de uma vida mediada por recursos abundantes. A inconformidade da menina é explicitada pela "gravidade" de seu caráter:

${ }^{66}$ Op. cit., p.p.119, 120. 
A primeira vez que esta gravidade da menina se the tornou mais patente foi uma tarde em que ela estivera a brincar no quintal da casa. O muro do fundo tinha uma larga fenda, por onde se via parte da chácara pertencente a uma casa da vizinhança. A fenda era recente; e Guiomar acostumara-se a ir espairecer ali os olhos, já sérios e pensativos. Naquela tarde, como estivesse olhando para as mangueiras, a cobiçar talvez as doces frutas amarelas que the pendiam dos ramos, viu repentinamente aparecer-Ihe diante, a cinco ou seis passos do lugar em que estava, um rancho de moças, todas bonitas, que arrastavam por entre as árvores os seus vestidos, e faziam luzir aos últimos raios de sol poente as jóias que as enfeitavam. Elas passaram alegres, descuidadas, felizes; uma ou outra lhe dispensou talvez algum afago; mas foram-se, e com elas os olhos da interessante pequena, que ali ficou largo tempo absorta, alheia de si, vendo ainda na memória o quadro que passara. $^{67}$

O episódio acima confirma as disposições da personalidade de Guiomar. A inevitável comparação entre as moças que passeavam do outro lado do muro, nos jardins ricos, e ela, no da modesta casa da mãe, evidenciam a barreira social que as dividem. A menina humilde e desprovida de perspectivas de um futuro promissor tem a realidade estampada diante de si como se fosse uma tela elegante na qual as jovens simbolizam felicidade e tranquilidade.

No já citado ensaio "A máscara e a fenda"68, Alfredo Bosi sugere que essa passagem pode ser a confirmação da hipótese defendida por Lúcia Miguel Pereira, segundo a qual os romances da primeira fase são quase

\footnotetext{
${ }^{67}$ A mão e a luva, p. 216.

${ }^{68}$ Op. cit., 437- 457.
} 
autobiográficos. Heroínas como Guiomar e laiá Garcia representariam a ascensão social completada pelo homem Machado de Assis. Bosi insiste ainda na idéia de que a principal função do trecho seria a reprodução da sociedade. Nesse caso, o muro funcionaria como uma clara divisão entre ricos e pobres. 0 trecho, contudo, parece ir além da representação social. Assim como o fragmento em que Julien aprecia, encantado, os oficiais do exército, este expressa e explicita as principais características psicológicas da personagem que serão desenvolvidas ao longo do romance. A gravidade e a conformidade já são anunciadas antes mesmo de Guiomar ter maturidade para entendê-las: "Que explicaria ela, se mal podia compreender a impressão que as cousas lhe deixavam?"

Filha da viúva de "um empregado subalterno não sei de que repartição do Estado" 69 , anunciava desde pequena ser viva, inteligente e capaz de adaptar-se rapidamente a cada nova situação que a vida lhe apresentava. Educada somente pela mãe até os treze anos, a menina é caracterizada como quem já tem potencial para ir além do que parecia ser o seu destino até o momento:

Guiomar não tinha dificuldade nenhuma em reter o que a mãe Ihe ensinava, e com tal afinco lidava por aprender, que a viúva, - ao menos nessa parte, - sentia-se venturosa. Hás de ser a minha doutora, dizia-Ihe muita vez; e esta simples expressão de ternura alegrava a menina e the servia de incentivo à aplicação. (...) tinha uma força de vontade superior aos seus

${ }^{69}$ A mão e a luva, p. 215. 
anos. Com ela, e a viveza intelectual que Deus Ihe dera, logrou aprender tudo o que a mãe lhe ensinara, e melhor ainda do que ela o sabia, desde que o tempo lhe permitiu desenvolver os primeiros elementos. ${ }^{70}$

A capacidade de adaptação de Guiomar se mostra ser ainda mais admirável quando, por uma sucessão de tragédias - a morte de sua mãe e da filha de sua madrinha -, a jovem tem a oportunidade de ocupar o lugar da filha da rica madrinha baronesa e de tornar-se o principal objeto de afeição por parte desta. Apesar de muito jovem, Guiomar é lúcida. Tem-Ihe verdadeiro afeto, mas não descuida de preparar o caminho que passa a trilhar daquele momento em diante, pois essa é a sua melhor, talvez única, chance de lograr sucesso e corresponder aos seus anseios. O empenho em adaptar-se à nova vida é constante:

Guiomar correspondia aos sentimentos daquela segunda mãe; havia talvez em seu afeto, aliás sincero, um tal encarecimento que podia parecer simulação. $O$ afeto era espontâneo; 0 encarecimento é que seria involuntário. (...) Pouco depois estabeleceu-se Guiomar definitivamente em casa da madrinha, onde a alegria reviveu, gradualmente, graças à nova moradora, em quem havia um tino e sagacidade raros. Tendo presenciado, durante algum tempo, e não breve, o modo de viver entre a madrinha e Henriqueta, Guiomar pôs todo o seu esforço em reproduzir pelo mesmo teor os hábitos de outro

${ }^{70}$ Idem. p.p. 215, 216 
tempo, de maneira que a baronesa mal pudesse sentir a ausência da filha. ${ }^{71}$

Ainda ilustrando a facilidade de adaptação social inerente à sua própria natureza:

Ao mesmo tempo que ia provando os sentimentos de seu coração, revelava a moça, não menos a plena harmonia de seus instintos com a sociedade que entrara. A educação, que nos últimos tempos recebera, fez muito, mas não fez tudo. A natureza incumbira-se de completar a obra, - melhor diremos, começá-la. Ninguém adivinharia, nas maneiras finamente elegantes daquela moça, a origem mediana que ela tivera; a borboleta fazia esquecer a crisálida. ${ }^{72}$

Esse tipo de vínculo, entre um parente carente e um rico, na obra de Machado de Assis foi também observado por Alfredo Bosi, no ensaio mencionado anteriormente. O crítico observa que essa relação combina "um interesse econômico inegável com uma tática de aproximação e envolvimento afetivo" ${ }^{73}$ do parente rico por parte do carente. Para Bosi, Guiomar é uma das personagens femininas machadianas capazes de sacrificar os desejos verdadeiros em nome da "fria eleição do espírito".

\footnotetext{
${ }^{71}$ A mão e a luva, p. p. 216, 217.

${ }^{72}$ Idem, p. 218.

${ }^{73}$ Op. cit., p. 437.
} 
A frieza, aliás, é uma das características mais ressaltadas de Guiomar. O narrador insiste nesse aspecto caracterizando-o de diversas maneiras, seja na plasmação psicológica ou nas atitudes e gestos, surgindo em diferentes circunstâncias. Quando se encontra com Estevão mostra-se "tranqüila e fria, sempre polida e grave, risonha às vezes, mas de um risonho à flor do rosto, que não Ihe alterava a serenidade e compostura." ${ }^{74}$ Despede-se dele "com um gesto friamente fidalgo"75. A governanta da casa, Mrs. Oswald, assim a descreve para a baronesa: "Sua afilhada tem uma alma singular; passa facilmente de entusiasmo à frieza, e da confiança ao retraimento." 76 Em uma discussão com a mesma governanta, Guiomar "olhou fria e longamente para a inglesa, com um desses olhares, que são, por assim dizer, um gesto da alma indignada."77 Também fria e imutável ao ler a carta de declaração de Jorge, um de seus pretendentes: "Guiomar leu a carta duas vezes, uma leitura de curiosidade, outra de análise e reflexão, e ao cabo da segunda achava-se tão fria como antes da primeira."78 $\mathrm{E}$ até na descrição da sua silhueta em uma significativa passagem na qual o narrador menciona a mineralidade de sua feição: "Na meia sombra que ali havia destacava-se o rosto marmóreo de Guiomar e a gentileza de seu talhe."79

Essa "frieza" mencionada pode ser relacionada ao cálculo e à contenção, necessários para que ela consiga a superação desejada. Tais

\footnotetext{
${ }^{74}$ A mão e a luva, p. 210.

${ }^{75}$ Idem, p. 211.

${ }^{76}$ Idem, p. 214.

77 Idem, p. 222.

${ }^{78}$ Idem, p. 232.

${ }^{79}$ Idem, p. 218.
} 
características revelam também o grande discernimento da protagonista frente aos obstáculos que encontra. A formação do caráter objetivo de Guiomar pode ser perfeitamente compreendida se considerarmos as pouquíssimas opções de que dispunha. Moça pobre, sem bens e sem dote, dependia completamente de sua figura e da precisão de suas decisões. Estas eram determinantes para que nossa personagem se mantivesse segura naquela família e, consecutivamente, naquela sociedade. Além da beleza, podia contar apenas com sua sagacidade. Tem contra si a origem, o drama familiar, o sexo e as condições históricas. Sua luta, portanto é - ao menos originalmente - mais árdua do que a dos homens, cuja vida em sociedade permitia deslocamentos, acesso aos estudos e probabilidades de carreira.

A área de atuação de Guiomar, como assinalamos no capítulo III, é muito restrita, já que Machado não a caracteriza como cortesã, cigana ou herdeira rica, lugares-comuns do século XIX. Sua possibilidade de ação é sempre - no âmbito familiar, burguês, recatado e algo provinciano do Rio de Janeiro àquela época. Daí a importância do uso do corpo (de modo extremamente comedido, mas atuante, como mostra a cena entre ela e Estêvão na chácara), do afeto para com a baronesa, como substituta da filha, da inteligência e da capacidade de avaliação das circunstâncias.

Como vimos, a narrativa de $A$ mão e a luva busca a valorização do íntimo e do particular, resultando na representação da família burguesa fluminense. Nessa conjuntura, a escolha de uma personagem feminina - como centro da atenção - é compreensível, visto que essa exploração parece ser algo emblemática na intenção de se reproduzir tal universo. 
Voltando ao romance francês, temos um quadro bem distinto, porque as intenções de Julien não são nunca de se agregar àquelas pessoas, pois sua adesão se dá superficialmente. Apesar de também adaptar-se rapidamente ao novo estilo de vida, sua conduta, desde a chagada à casa da família de Rênal, é de outra natureza. Ele não pretende ficar permanentemente com a família nem de fazer parte dela, de modo que o embate é latente já no primeiro momento. O sentimento de inadequação leva a uma constante dissimulação, como mostra o trecho de primeiro encontro com Mme de Rênal:

II eut sur-le-champ l'idée hardie de lui baiser la main. Bientôt il eut peur de son idée; un instant après, il se dit: II y aurait de la lâcheté à moi de ne pas exécuter une action qui peut m'être utile, et diminuer le mépris que cette belle dame a probablement pour un pauvre ouvrier à peine arraché à la scie. $^{80}$

Fica claro, nessa passagem, que a agregação de Julien será de um caráter diverso daquele de Guiomar. Enquanto esta se esforça para ser membro cada vez mais natural da família que a acolheu, passando a possuir sentimentos, até certo ponto, verdadeiros com o novo núcleo, aquele mantém, no seu íntimo, inabalada a barreira que o separa daqueles considerados inimigos. Há, no fragmento de texto acima, palavras indicadoras de sentimentos complexos. Temos acesso ao monólogo interior de Julien, por meio do discurso indireto livre, nesse momento e em vários outros. Peur,

\footnotetext{
${ }^{80}$ Le rouge et le noir, p. 375.
} 
lâcheté, mépris e pauvre são expressões que dão o tom do que o protagonista pensa a respeito de si próprio. O contraste da imagem do menino mal vestido com a mulher elegante potencializa a auto-imagem degradada do jovem. Outro ponto interessante de se notar é a predisposição à ação em benefício próprio; os segmentos idée hardie e executer une action qui peut m'être utile são exemplos dessa atitude. Na cena seguinte, após trocar de vestimentas e recobrar a calma, o cálculo parece ser o senhor de seus atos:

Enfin, Julien parut. C'était un autre homme. C'eût été mal parler que de dire, qu'il était grave; c'était la gravité incarnée. II fut presenté aux enfants, et leur parla d'un air qui étonna M. de Rênal lui-même. ${ }^{81}$

Julien, assim como Guiomar, desenvolve certa desconfiança permanente do meio em que vive como procedimento de defesa. Segundo Crouzet, a dissimulação de Julien opera em dois sentidos. O primeiro seria a argumentação em favor de seu comportamento levando em conta as questões históricas e sociais: "il est condamné à mentir pour se protéger, il est le plus faible, le paria, l'exclu, le minoritaire absolu force à mimer l'adhésion aux normes des puissants". Por outro lado, sua hipocrisia não se sustenta, pois, ao

${ }^{81}$ Le rouge et le noir, p. p. $377,378$. 
final, ele acaba por exibir seu projeto de triunfo através de seus atos imprudentes. $^{82}$

No caso da personagen feminina, a adesão à causa é, em grande parte, verdadeira. Guiomar oferece amostras incontestáveis do laço que a une à madrinha, na ocasião da morte de Henriqueta. Aqui, o aprendizado e o domínio do código social parecem ser fundamentais para o êxito da personagem que anseia ascender. Dois exemplos célebres de arrivistas na literatura do século XIX mencionados na introdução de nosso estudo são Eugène de Rastignac de Le père Goriot (1835) e Lucien de Rubempré de Illusions perdues (1837), ambos de Balzac. Rastignac percebe a importância do domínio desse código e se empenha em aprendê-lo; o êxito do jovem bacharel é previsível. O mesmo não ocorre com Lucien e Julien. Sendo aquele possivelmente o arrivista mais ingênuo dentre as personagens do enorme universo balzaciano, o jovem camponês, iludido com a vida parisiense, não se esforça o suficiente e sofre as consequências por não ter tido o expediente necessário. No caso daquele, as transformações ocorrem em um nível superficial, somente nas aparências. Impulsivo e instintivo, Julien demonstra sempre estar escondendo algo, sua conformação aos ambientes não é natural nem completa. Temos a impressão de ser uma personagem cindida entre o que ele realmente é e o que parece ser. Essa cisão far-se-á presente por todo o enredo e, pode-se dizer que é uma das principais chaves da trama, sobretudo nos capítulos finais, onde irrompe a configuração do herói romântico, desajustado e, ao mesmo tempo, vítima e

\footnotetext{
${ }^{82}$ Op. cit., p.p. $124,125$.
} 
beneficiário do sentimento amoroso. Julien prefere morrer - ligado ao encanto da precária relação com Madame de Rênal - a "jogar o jogo" da sociedade.

Diferentemente do percurso da personagem francesa, Guiomar exemplifica um movimento completo e bem-sucedido de mudança de uma classe inferior para outra superior, por meio de dois procedimentos que integram o processo de aquisição do código social: primeiramente a grande facilidade de adaptação à nova posição e, em seguida, a manutenção da mesma através da completa transformação que culmina no casamento adequado. 


\section{Capítulo V}

\section{A corporificação artística "stricto sensu"}

\section{O romance de embate de classes: Le rouge et le noir}

$\mathrm{Na}$ sociedade francesa da Restauração, dominada pela aristocracia e pelo clero, poucos, ou melhor, raros conseguem entrar no círculo fechado chamado "bonne société". Michel Guérin mostra que ela concentra para si todos os bens - as mulheres, o dinheiro e a influência de poder - de modo que esse conjunto representa certo ideal de prazer desejado por todos. Evidentemente, os "bem-nascidos" têm larga vantagem nessa disputa; os que integram a grande parte da sociedade desprezada têm de se armar com seus próprios talentos e uma grande paciência para serem notados e conseguirem, com o tempo, casamento e posses que os levem a ocupar lugar relevante nesse meio. ${ }^{83}$ Essa trajetória, mesmo quando bem-sucedida, tem como constante os embates entre as pessoas pertencentes a um mundo exclusivo e as que anseiam entrar para esse universo fechado. Nesse momento, a aristocracia dá o tom em matéria de modos, convenções, gosto ao mesmo tempo em que ensina as regras de conhecimento e de critérios distintivos. ${ }^{84}$

Todo o percurso de Julien Sorel será permeado por esse embate, do nível mais superficial - o modo como se veste e se comporta - ao mais simbólico, quando ele deseja a liberdade aos seus iguais, desprivilegiados.

\footnotetext{
${ }^{83}$ Op. cit., p. 26.

${ }^{84}$ Acompanhamos aqui o pensamento de Jacques Dubois na obra já citada, p. 35.
} 
Ambicioso, suas estratégias são exaustivamente imaginadas por ele e 0 conflito funciona como uma espécie de combustível que o continua movendo em direção aos seus objetivos. O imaginar de Julien Sorel se repete com tal insistência que se constitui como procedimento narrativo de como a personagem é constituída nesse ambiente de disputa. Michel Guérin define o ambicioso com um "type singulier, (...) mû par une volonté ordonnatrice, dans l'ensemble et le detail, des rêves, des sentiments, des calculs et des actes" ${ }^{85}$ Vejamos então, como no próprio texto, essas características tomam forma literária e conformam a mudança progressiva da personagem.

Ao chegar à casa dos de Rênal, Julien, vestido modestamente como camponês, experimenta seu primeiro embate no encontro com Mme de Rênal. Tal era a postura acanhada do preceptor, que a dona da casa tem a impressão de que se tratava de uma mocinha disfarçada pedindo algum tipo de ajuda. Aliviada ao perceber que o rapaz que cuidaria de seus filhos não passava de um jovem acanhado, sente-se à vontade para conhecê-lo melhor. $\mathrm{Na}$ sequência dessa cena, há a primeira transformação de Julien. Ao trocar suas roupas pelo costume preto encomendado por Monsieur de Rênal, muda também sua postura, conforme já vimos. A timidez se transforma em gravidade, enquanto o acanhamento dá lugar a certa confiança:

(...) le sentiment d'orgueil que lui donnait le contact d'habits si différents qu'il avait coutume de porter, le mettait tellement hors de lui même, et il avait tant d'envie de cacher sa joie, que tous

${ }^{85}$ Op. cit., p. 34 
ses mouvements avaient quelque chose de brusque et fou. (...) C'était un autre homme. C'eût été mal parler que de dire, qu'il était grave; c'était la gravité incarnée. ${ }^{86}$

Parece que Julien compreende, desde o início, o papel que deve atuar para ter alguma chance de penetrar naquele tipo de espaço. Na cena seguinte, em que é apresentado às crianças e tem a oportunidade de expor seu conhecimento de latim e da Bíblia, a gravidade se soma à sua grande capacidade de se comunicar bem, um dos talentos principais nas camadas superiores às quais passa a ter acesso. ${ }^{87}$ Essas mudanças em sua conduta parecem não modificar, contudo, a essência de Julien. Percebemos, ao longo da narrativa dois movimentos distintos que se intercalam: por um lado, a mudança constante e gradual de seus modos, por outro, o deslocamento permanente sentido pela personagem nos três ambientes pelo qual ele passa: a casa da família dos de Rênal, o seminário de Besançon e a mansão de La Mole. Se por fora, ele exala gravidade e eloqüência, no seu íntimo prevalece o inconformismo com o modus vivendi do mundo no qual foi admitido:

Pour lui, il n'éprouvait que haine et horreur pour la haute société ou il était admis, à la vérité au bas bout de la table, ce

\footnotetext{
${ }^{86}$ Le rouge et le noir, p. 377.

${ }^{87}$ Segundo Michel Guérin, a capacidade verbal é vital nesse sistema de conquistas, pois explicita a inteligência e o talento: “Dans un univers qui n'est pas à jamais revé d'interdits, marqué plutôt par une plasticité sociale inédite, ou l'action souvent dépend de l'entraînement du verbe, la volonté devient la pièce maîtresse du système de conquête des "capacités"', Op. cit., p. 39.
} 
qui explique peut-être la haine et l'horreur. II y eut certains dîners d'apparat ou il put à grande peine contenir sa haine pour tout ce qui l'environnait. Quels éloges de la probité! s'écriait-t-il, on dirait; et cependant quelle considération, quel respect bas pour un home qui évidemment a doublé et triplé sa fortune, depuis qu'il administre les biens des pauvres! je parierais qu'il gagne meme sur les fond destinés aux enfants trouvés, à ces pauvres, dont la misère est encore plus sacrée que celle des autres! $!^{88}$

A posição psicológica de Julien se mantém intacta; apesar das aparências, ele despreza profundamente aqueles com quem convive. O homem em questão no trecho acima é Monsieur de Valenod, personagem que representa mais enfaticamente a burguesia provinciana inescrupulosa, não medindo esforços para se enriquecer cada vez mais, conquistando, assim, mais poder político e social. O comportamento cínico e grosseiro de Valenod não evolui com as conquistas financeira e política; ele se torna, aos olhos de Julien, a personagem mais detestável daquele círculo. Monsieur de Rênal, mesmo sendo burguês e obtendo vantagens de sua posição, mantém certa compostura, pois tem como modelo o comportamento aristocrático.

Outra estratégia de Julien, ao lado do esforço em aprimorar seu comportamento, consiste na conquista da dona da casa, Madame de Rênal. Influenciado por Napoleão e suas estratégias de guerra, inclusive no trato com as mulheres, a obtenção de favores femininos é vista como um dever. A primeira tarefa a qual ele impõe a si mesmo consiste em fazer com que

\footnotetext{
${ }^{88}$ Le rouge et le noir, p.p. 379, 380.
} 
Madame de Rênal o deixe tocar sua mão. O envolvimento entre Julien e a dona da casa progride aos poucos, com a obtenção de pequenas liberdades por parte daquele, mas situações inevitáveis lembram a ele todo o tempo a distância que os separa. Sempre que é humilhado pelo marido, ele estende a ela a revolta que sente. Em uma passagem na qual é reprimido por Monsieur de Rênal por não ter cuidado das crianças durante toda uma manhã, o processo se repete:

Monsieur de Rênal marchait tout près d'eux; sa présence augmentait la colère de Julien. II s'aperçut tout à coup que Mme de Rênal s'appuyait sur son bras d'une façon marquée; ce mouvement lui fit horreur, il la repoussa avec violence et dégagea son bras. ${ }^{89}$

Essa repulsão, seguida de um olhar frio e de grande desprezo é percebido com sagacidade por Madame Derville, prima e amiga de Madame de Rênal, presença constante na casa desta. Nesse momento, o narrador justifica, através do espanto de Madame Derville, o comportamento dos revolucionários frente às constantes humilhações sofridas e relaciona, pela primeira vez, Julien a Robespierre ${ }^{90}$ :

\footnotetext{
${ }^{89}$ Le rouge et le noir, p. p. 399, 400.

${ }^{90} \mathrm{~A}$ analogia entre Julien e as principais figuras revolucionárias, Robespierre e Danton, permeia toda a narrativa. Na segunda parte do romance, como veremos mais adiante, a figura de Danton mediará seu envolvimento com Mathilde de La Mole.
} 
Ce regard étonna Mme Derville, et l'eût surprise bien advantage si elle en eût deviné la véritable expression; elle y eût comme un espoir vague de la plus atroce vengeance. Ce sont sans doute de tels moments d'humiliation qui on fait les Robespierre. ${ }^{91}$

A experiência recente da Revolução mantém a desconfiança presente em todos os níveis sociais retratados na obra. Napoleão, Robespierre e Danton são paradigmas que têm funções distintas relativas à personagem que alude a eles. Para Julien, representam modelos a serem seguidos; para Mme de Derville, Mme de Rênal e Mathilde de La Mole constituem influência importante no comportamento de jovens arrivistas como o protagonista. Importante notarmos que, apesar das querelas específicas com Monsieur de Rênal e sua esposa, o narrador indica que o ressentimento de Julien transcende as intrigas particulares. Daí a função fundamental das figuras históricas da Revolução. O embate se dá contra um grupo, não se restringindo apenas a essas figuras, de forma que o conflito possa ser abrangido às duas classes tratadas, a dos pobres e a dos burgueses:

Le maire de Verrières était bien toujours, à ses yeux, le représentant de tous les riches et de tous les insolents de la terre; mais Julien sentait que la haine qui venait de l'agiter, malgré la violence de ses mouvements, n'avait rien de personnel. S'il eût cesse de voir M. de Rênal, en huit jours il

\footnotetext{
${ }^{91}$ Le rouge et le noir, p. 400.
} 
l'eût oublié lui, son château, ses chiens, ses enfants et toute sa famille. ${ }^{92}$

Mesmo no desenvolvimento do romance com Madame de Rênal, Julien trata da questão com objetividade no início, ressaltando sua posição de doméstico e a dela de herdeira rica. Seguindo passo a passo as etapas no dever de conquistar Louise, Julien avança cada vez mais em suas investidas. A falta de afetação e a completa ingenuidade daquela impedem-na de perceber o plano inscrito deste. Com posição privilegiada para analisar os acontecimentos, pois vê a situação com distanciamento, Madame Derville tem mais clareza da situação que todos os outros integrantes da família:

Ton petit précepteur m'inspire beaucoup de méfiance, lui disait quelquefois Mme Derville. Je lui trouve l'air de penser toujours et de n'agir pas qu'avec politique, c'est un surnois. ${ }^{93}$

A expressão surnois ${ }^{94}$, utilizada aqui por Mme Derville, aparecerá em outros momentos da narrativa para descrever o comportamento de Julien. Significativa, pois não apenas indica a dissimulação dos sentimentos reais, como tem também, quase sempre, conotação de má intenção. Essa malícia parece estar na impressão que as personagens periféricas, como Mme

\footnotetext{
${ }^{92}$ Le rouge et le noir, p. 405.

${ }^{93}$ Idem, p. 422.

${ }^{94}$ A grafia contemporânea é sournois.
} 
Derville, têm de Julien. As figuras mais centrais como Louise e Mathilde se aproximam mais da compreensão da complexidade de seu caráter, pois levam em conta sua dificuldade de adaptação aos novos espaços.

Uma das personagens mais carismáticas, presente na segunda parte da narrativa, o Conde Altamira, tem muita relevância, porque representa também valores revolucionários. Há, desde o começo, uma grande empatia entre ele e Julien. Dentre todas as figuras que circulam nos grandes salões de La Mole, Fervaques e Retz, o Conde Altamira parece ser o único portador de certa autenticidade. Apesar de ter tido seus privilégios restituídos, a sociedade aristocrática perdeu a fé em si mesma. O hibridismo social é completo, pois encontramos no mesmo salão, lado a lado, personagens tão díspares quanto o Marquês de La Mole, o Conde Altamira e Julien Sorel. Este se vê fascinado pelo Conde ao saber que ele foi exilado por ser acusado de conspiração em sua terra, Nápoles. Altamira explica a Julien que não há mais paixões verdadeiras na França da Restauração, tudo são alianças de interesses nesse meio que se caracteriza por convenções estabelecidas, ou melhor, restabelecidas. Interessante notar também que Mathilde de La Mole participa dos diálogos entre Altamira e Julien, interessando-se por esse exatamente quando ouve o Conde afirmar o deslocamento dele próprio e do secretário do Marquês:

Vous et moi, à ce diner, nous serons les seuls purs de sang, mais je serais méprisé et presque haï, comme un monstre 
sanguinaire et jacobin, et vous, méprisé simplement comme homme du peuple intrus dans la bonne compagnie.

Rien de plus vrais, dit Mlle de La Molle. ${ }^{95}$

A presença do Conde Altamira ressalta a curiosa integração de Julien àquele ambiente, ao mesmo tempo em que explicita a situação aos olhos de Mathilde. Veremos mais adiante que o envolvimento dos dois acontecerá por uma sucessão de sentimentos contraditórios por parte de ambos.

A conclusão acerca das mudanças irreversíveis ocorridas na França no século XIX, vem, justamente, da personagem de maior prestígio social de Le rouge et le noir, o Marquês de La Mole. Ao tomar conhecimento da opção da filha por Julien, o pai desabafa exasperado:

Qui l'eût pu prévoir? se disait-il. Une fille d'un caractère si altier, d'un génie si élevé, plus fière que moi du nom qu'elle porte! dont la main m'était demandée d'avance par tout ce qu'il y a de plus illustre em France! II faut renoncer à toute prudence. Ce siècle est fait pour tout confondre! Nous marchons vers le chaos! $!^{96}$

Apesar de representar a aristocracia mais prestigiosa, o narrador trata a personagem do Marquês de La Mole com certo respeito. Homem sábio e, por vezes, generoso, ele encarna o verdadeiro nobre que, mesmo

\footnotetext{
${ }^{95}$ Le rouge et le noir, p. 614.
}

${ }^{96}$ Idem, p. 743. 
desfrutando das vantagens de sua posição, preza por sentimentos e conduta corretos. O Marquês tem algum apreço por Julien, porque reconhece nele qualidades que não encontra nem em seu próprio filho. Agracia-o com a medalha da Légion d'Honneur, aceitando posteriormente inclusive o casamento de Mathilde e Julien. Só recusa a união, após receber a carta difamatória de Madame de Rênal.

A narrativa de Le rouge et le noir nos apresenta amostras de muitos tipos possíveis na sociedade francesa do século XIX em seus diversos aspectos. Temos estampadas personagens da província e de Paris, camponeses, burgueses, revolucionários, nobres e religiosos, sendo que as relações entre os variados universos constituem um dos assuntos mais ricos e interessantes da obra. A inserção de Julien Sorel nesses núcleos mostra-se fundamental, pois não desvenda apenas as relações intra-sociais, como também contribui para a construção psicológica complexa do protagonista.

Romance de adequação social: a baronesa e seu advogado

Como vimos acima, o embate entre classes está presente em todos os espaços de Le rouge et le noir, principalmente nos círculos de Verrières e Paris. Pode-se dizer que cada núcleo do romance representa uma etapa da inserção social de Julien, de modo que sua ascensão ocorre progressivamente. 
Em A mão e a luva, temos praticamente um único centro, a mansão da baronesa, que, eventualmente abrange também a propriedade de Luís Alves, pois são propriedades contíguas. A casa humilde da infância de Guiomar é mencionada uma única vez, não tendo relevância na estrutura da obra. Não há dificuldade em penetrar o espaço ambicionado por parte de Guiomar, como no caso francês, visto que ela já se encontra perfeitamente acomodada na residência da madrinha. Sua adesão aos novos hábitos acontece gradual e suavemente a partir da morte de Henriqueta, filha da baronesa:

Ao mesmo tempo que ia provando os sentimentos de seu coração, revelva a moça, não menos, a plena harmonia de seus instintos com a sociedade em que entrara. A educação, que nos últimos tempos recebera, fez muito, mas não fez tudo. A natureza incumbira-se de completar a obra, - melhor diremos, começá-la. Ninguém adivinnharia, nas maneiras finamente elegantes daquela moça, a origem mediana que ela tivera; a borboleta fazia esquecer a crisálida. ${ }^{97}$

Também não podemos dizer que o envolvimento amoroso depara esse tipo de dificuldade; a casa do pretendente favorito se separa apenas por uma cerca da que habita a moça. Além da facilitação geográfica, a baronesa e o advogado travam relações profissionais e pessoais, tornando natural a presença deste na residência daquela. Na passagem em que Luís Alves

${ }^{97}$ A mão e a luva, p. 218. 
prontifica-se a introduzir Estevão na mansão, verificamos a naturalidade de sua admissão em tal residência:

\begin{abstract}
A promessa cumpriu-se pontualmente. Luís Alves apresentou Estevão à baronesa, na seguinte noite, como seu companheiro e amigo, como advogado capaz de zelar os interesses da ilustre cliente. ${ }^{98}$
\end{abstract}

Vemos que a presteza da ação - "na noite seguinte" - revela certa familiaridade nessas relações. Não há aviso prévio, nem estranhamento por parte da dona da casa, que considera perfeitamente normal a visita inesperada. Notamos que, em linhas gerais, as relações são bem mais informais se comparadas às vistas na obra francesa, revelando, desde logo, acordo de interesses, reciprocidade social e possibilidade de alianças.

Aqui, convém notar que o narrador prepara não apenas as peças do jogo social como lhe dá a feição necessária para que tal ocorra sem excessos de qualquer ordem, à parte a fatura algo paródica do "romântico" Estevão.

O íntimo, o familiar, o comedido das situações só têm a ganhar com o fato de as personagens expressarem afetos e interesses comuns, sem alarde ousofreguidão (algo só desmentido pelo poeta).

Ademais, a semelhança e empatia entre as partes são divulgadas através das palavras de Jorge a respeito de Luís Alves:

${ }^{98}$ A mão e a luva, p. 220. 
_ O senhor é o menos assíduo, talvez, das pessoas que lá vão, apesar de vizinho; só agora o vejo ali mais amiúdo; entretanto é como flor que se trai pelo aroma; minha tia tem a seu respeito a melhor opinião do mundo; acha-lhe uma gravidade, e eu também a sinto, e nem compreendo que o homem possa ser outra cousa. Os tais espíritos fúteis...99

Esse trecho, além de ressaltar o acordo existente, antecipa a aceitação do futuro marido de Guiomar naquele meio. Se a baronesa tem estima e respeito pelo advogado, a vontade da moça poderá ser mais facilmente atendida. Na ocasião da eleição do rapaz a deputado, a convivência se estreita e a iniciação na vida pública chama a atenção de Guiomar:

No quarto dia recebeu um bilhete da baronesa que 0 cumprimentava pela eleição. A mala do Norte chegara, e com ela a notícia da vitória eleitoral. Estava Luís Alves deputado; ia enfim dar a sua demão no fabrico das leis.(...) Luís Alves apressou-se a ir agradecer à baronesa a felicitação. Guiomar teve um leve estremecimento quando o viu, mas recebeu-o tranqüila e risonha, quase indiferente.(...) Guiomar, entretanto, obervava-o a espaços, de revés, como a querer surpreendê-lo; a pouco e pouco, porém, o seu olhar foi sendo mais direto e firme. O de Luís Alves era natural e igual como antes era, como era ainda agora com todos. ${ }^{100}$

\footnotetext{
${ }^{99}$ Idem, p.242.

${ }^{100}$ A mão e a luva, p. 252.
} 
A adequação passa a ser cada vez mais evidente. A passagem acima desvenda parte do processo de aproximação dos interessados. As interações amistosas dos dois lados somadas ao prestígio político eminente despertam o mérito do jovem aos olhos de Guiomar. Contudo, como atesta toda a narrativa, seu interesse se mantém comedido e sua conduta reservada. Igualmente contidos, os modos de Luís Alves condizem com as expectativas da jovem, além de não ameaçarem os valores da ilustre proprietária. A comunhão harmônica, constatada aqui, será selada pelo acordo final, simbolizado pelo casamento, como veremos mais amiúde adiante.

\section{O caráter único de Julien Sorel}

Julien Sorel não se tornou uma das principais personagens da literatura francesa por acaso. Figura impossível de ser reduzida a simples definições por sua complexidade, inclassificável, até mesmo pela crítica contemporânea, o protagonista ambicioso deu e continua dando margem às mais distintas, nem por isso opostas, interpretações. O crítico stendhaliano Michel Crouzet aponta múltiplas facetas de Julien, no estudo que fez acerca de Le rouge et le noir, de forma que a passagem abaixo pode ser um bom ponto de partida para as observarmos, em seguida, no texto de Stendhal:

(...) Julien est au-delà des catégories, des catégories morales et des catégories psychologiques: il est établi dans un 
ensemble d'antinomies, posé dès le début où son air de jeune fille et sa délicatesse physique sont unis à l'énergie farouche et concentrée, une naïveté presque sotte à une ruse de principe; le roman décrit une "éducation", une métamorphose du petit paysan buté et battu qui a le "fanatisme illetré" (...) II est entre des qualités contraires, toujours extrême, toujours autre, pris dans une continuelle tension des contraires, conduit enfin à "la gloire" noire de l'infamie $(. . .)^{101}$

Moldado pelos poucos livros que conhece, Julien tem, como modelos, figuras que traçaram um percurso incompatível com a realidade francesa dos anos de 1830, na qual ele se encontra. Munida de sentimentos opostos, como aponta Crouzet, sua personalidade abarca vaidade, orgulho, ambição, amor, inferioridade e superioridade. ${ }^{102}$ Sua construção, física e psicológica, é bastante elaborada e revela, em cada cena, um aspecto do emaranhado de características. Vejamos a primeira descrição física e psicológica de Julien, pois ela já apresenta os principais elementos que serão resgatados durante todo o romance:

II avait le joues pourpres et les yeux baissés. C'était un petit jeune home de dix-huit à dix-neuf ans, faible en apparence, avec des traits irréguliers, mais délicats, et un nez aquilin. Des grands yeux noirs, qui dans les moments tranquilles, annonçaient de la réflexion et du feu, étaient animés en cet instant de l'expression de la haine la plus féroce. Des cheveux

\footnotetext{
${ }^{101}$ CROUZET, Michel. Op. cit., p.108.

102 Op. cit., p. 108.
} 
châtain foncé, plantés fort bas, lui donnaient un petit front, et, dans les moments de colère, un air méchant. Parmi les inombrables variétés de la physionomie humaine, il n'en est peut-être point qui se soit distinguée par une spécialité plus saisissante. ${ }^{103}$

Se notarmos bem, há termos que se contrapõem em quase todas as sentenças. O vermelho vivo das bochechas representa símbolos elevados; a palavra pourpre simboliza riqueza, alta dignidade social, dignidade soberana e dignidade religiosa, ou seja, tudo o que Julien aspira e que, de algum modo, possuirá. A cor também pode ser associada ao termo "feu", que consiste no traço mais marcante de seu olhar e, consequentemente, de sua personalidade. No entanto, os olhos baixos se seguem, provavelmente por causa do ambiente hostil em que se encontra na companhia dos pais e dos irmãos que o humilham e castigam. Em seguida, a aparência frágil e delicada se opõe ao nariz forte, aquilino. Esta característica é uma alusão evidente a Napoleão cujo destino é simbolizado pela águia. Os olhos negros revelam, mais uma vez, o rubro do fogo, sendo este o elemento descritivo citado insistentemente ao longo de toda a narrativa. O olhar denuncia também a reflexão, companheira fiel de Julien e mediadora de muitos dos seus atos, apesar de sua impulsividade. Segundo Michel Guérin, o discurso que Julien faz continuamente a si mesmo constitui uma linha importante da obra:

${ }^{103}$ Le rouge et le noir, p. 364. 
Dans Le rouge et le noir, Stendhal emboîte le récit que Julien Sorel se fait à lui-même ("il se disait") dans celui de ses faits et ses gestes. II y a comme un écho qui creuse la narration et y introduit le débat, cette scission qui est le signe du sujet. Le discours intérieur est le lieu propre de l'imagination, pont jété entre le moi peint par le romancier et celui qui se prend luimême en charge, et de la surface de signes linéaires, fait surgir un volume psychique.(...) Le psychisme de l'ambitieux est tramé dans l'imaginaire et le conflit: l'ambition est une névrose appliquée. $^{104}$

Da introspecção, da repetição imaginativa passamos a uma imagem muito forte de ódio - la haine la plus féroce - que, desde a primeira juventude, denota o deslocamento da personagem em relação à sua origem. A frase enfática e afirmativa que conclui sua fisionomia pode ser considerada como o estabelecimento de sua especificidade. Julien não é um herói no sentido pleno e tradicional da palavra, mas sim do moderno que não representa mais a coletividade, mas uma fração dela em luta com outras frações. Mais antipático que simpático, ele encarna uma revolta que será abrandada apenas no desfecho da narrativa, com a proximidade da morte. ${ }^{105}$

Além da percepção do narrador, as impressões das outras personagens a respeito da singularidade de Julien são bastante reveladoras. A sua construção se sustenta sempre pela diferença; diferença em relação ao ${ }^{104}$ GUÉRIN, Michel. Op. cit., p. 38.

${ }^{105}$ A respeito do caráter do herói, Michel Crouzet chega a dizer que Julien Sorel antecipa Vautrin, personagem balzaciana da Comédie Humaine, que aparece pela primeira vez em Le Père Goriot. Op. cit., p. 109. 
espaço, às outras personagens e às regras sociais estabelecidas. Essa contestação inerente a ele é percebida até por Madame de Rênal, exemplo maior de ingenuidade e bondade da obra:

Dans le salon, quelle que fût l'humilité de son maintien, elle trouvait dans ses yeux un air de supériorité intellectuelle envers tout ce qui venait chez elle. ${ }^{106}$

Já no capítulo seguinte, há duas passagens complementares muito interessantes, do encontro entre o abade Chélan e Julien no qual aquele identifica e expõe a este suas particularidades de espírito. Através da percepção do religioso, Julien passa a perceber a si mesmo com maior clareza. Vejamos:

[Abade Chélan] J'entrevois avec peine, au fond de votre caractère, une ardeur sombre qui ne m'annonce pas la modération et la parfaite abnégation des avantages terrestres nécessaires à un prêtre, j'augure bien de votre esprit (...) [Julien] Cette ardeur secrète dont il me parle, c'est mon projet de faire fortune. ${ }^{107}$

\footnotetext{
${ }^{106}$ Le rouge et le noir, p. 387.

${ }^{107}$ Le rouge et le noir, p. p. 389, 390.
} 
A imagem do olhar com ardor, "olhar de fogo", vai se repetir incansavelmente no decorrer do romance reafirmando em muitos capítulos a paixão inabalável de Julien por seu plano ambicioso. Quando recusa a proposta de Fouqué para levar uma vida modesta nas montanhas: "qui me dit que j'aurais encore le feu sacré avec lequel on se fait un nom"108; a percepção que Mathilde tem da identificação de Julien com o Conde Altamira, um condenado à morte: "Son oeil est plein d'un feu sombre; il a l'air d'un Prince déguisé; son regard a redoublé d'orgueil”109; ainda no diálogo entre Julien e o Conde: "- Alors, reprit Julien l'oeil en feu, vous ne saviez pas le jeu, maintenant... (...) Ses yeux exprimaient le feu de la conscience et le mépris des vains jugements des hommes"110.

A intensidade do semblante, a paixão pela ambição e a reflexão incessante são sintomas de um tema mais amplo, a "idéia fixa". Essa préconcepção, ou melhor, essa convicção pode ser considerada um dos assuntos dominantes da obra. A "idéia fixa" aparece e reaparece nos mais diversos contextos ocasionando, em cada um deles, cogitações novas. Esse processo contínuo dá certo ritmo à história ao mesmo tempo em que acompanha a transformação "progressiva"111 de Julien. Quando decide invadir o quarto de Madame de Rênal, ele o faz impulsionado pelo dever que se auto-impôs. Em

\footnotetext{
${ }^{108}$ Idem, p. 416.

${ }^{109}$ Idem, p. 611.

${ }^{110}$ Le rouge et le noir, p. 615.

${ }^{111}$ Sabemos que a transformação de Julien não é exatamente progressiva, pois, ao final da trama, sua busca ligada ao sentimento é vencedora.
} 
suas investidas, esse sentimento de obrigação far-se-á presente, como profere o narrador:

II craignait un remords affreux et un ridicule éternel, s'il s'écartait du modèle idéal qu'il se proposait de suivre. En un mot, ce qui faisait de Julien un être supérieur fut précisement ce qui l'empêcha de goûter le bonheur qui se plaçait sous ses pas. (...) Julien était trop fidèle à ce qu'il appelait le devoir, pour manquer à exécuter de point en point ce qu'il s'était prescrit. ${ }^{112}$

\section{O caráter apenas particular de Guiomar e Luís Alves}

Se Julien Sorel possui características excepcionais as quais the permitem adentrar ambientes exclusivos, Guiomar e Luís Alves não precisam de tanto para manter-se em posição privilegiada e alcançar lustre social. São dotados, naturalmente, de perspicácia e prontidão, mas lançam mão de recursos mais modestos para atingirem seus alvos. Enquanto as personalidades de Julien e Mathilde são construídas por meio de contraste, as de Luís Alves e Guiomar o são por semelhança. A oposição em A mão e a luva é feita, sobretudo, na comparação entre Estevão e o casal. A postura "romântica" do colega, também advogado, destaca ainda mais a atitude prática

\footnotetext{
$\overline{112}$ Le rouge et le noir, p. 426,429 .
} 
dos ambiciosos. Não por acaso, a primeira descrição de Luís Alves no capítulo I, é antecedida pela exposição do estilo sonhador de seu amigo:

\begin{abstract}
Estevão, dotado de extrema sensibilidade, e não menor fraqueza de ânimo, afetuoso e bom, não daquela bondade varonil, que é apanágio de uma alma forte, mas dessa bondade mole e de cera, que vai à mercê de todas as circunstâncias, tinha, além de tudo isso, o infortúnio de trazer ainda sobre os óculos cor-de-rosa de suas virginais ilusões. Luís Alves via bem com os olhos da cara. Não era mau rapaz, mas tinha o seu grão de egoísmo, e se não era incapaz de afeições, sabia regê-las, moderá-las, e sobretudo guiá-las ao seu próprio interesse. ${ }^{113}$
\end{abstract}

A sensibilidade e a bondade de Estevão se chocam com a praticidade e egoísmo de Luís Alves. A volubilidade daquele se opõe à firmeza deste. Os traços de Estevão, Luís Alves e Guiomar intercalam-se no decorrer da obra repetidamente, de forma que esse procedimento narrativo faz com que o leitor apreenda a grande diferença de caráter existente entre o primeiro e o casal. Da mesma forma que o narrador contrapõe as naturezas dos rapazes, ele aproxima a de Guiomar e seu preferido em várias cenas, como a seguinte:

Guiomar, no meio das afeições que a cercavam, sabia manterse superior às esperanças de uns e às suspeitas de outros. Igulamente cortês, mas igualmente impassível para todos,

${ }^{113}$ A mão e a luva, p. 200. 
movia os olhos com a serenidade da isenção, não namorados, nem sequer namoradores. ${ }^{114}$

Afetiva com a madrinha, mas indiferente ao cortejo da maioria. Centrada em seu intento, ela conserva a tranqüilidade de quem planeja com cuidado o futuro. Desprivilegiada por sua origem, Guiomar aprende a ponderar as situações, de maneira a agir conforme seus objetivos, sem, contudo, estremecer o laço fundamental com a madrinha, conforme percebemos na situação delicada relativa à união indesejada com Jorge:

Até que ponto chegaria entretanto seu adorador, se ela 0 desatendesse logo; e, dado o amor que a baronesa tinha ao sobrinho, até que ponto a recusa iria magoá-la? Guiomar varreu do espírito os receios que the nasciam de tais interrogações; mas sentiu-os primeiro, pesou-os antes de os arredar de si, o que revelará ao leitor em que proporção estavam nela combinados o sentimento e a razão, as tendências da alma e os cálculos da vida. ${ }^{115}$

Há, no trecho acima, certa atmosfera que remete à matemática, indicando o discernimento, presente na personalidade da protagonista, algo destacado pelo

\footnotetext{
${ }^{114}$ A mão e a luva, p. 224.

${ }^{115}$ A mão e a luva, p. 233.
} 
narrador, desde o início do romance. O verbo "pesar" e as expressões "proporção" e "cálculo" confirmam essa inclinação.

Assim como Guiomar, Luís Alves sustenta sua estabilidade em todas as circunstâncias, inclusive na relevante decisão de pedir a mão de sua futura esposa, quando esta o ordene que o faça. Tendo pretensões de alcançar posição destacada na sociedade em que se encontra, o jovem age de forma pertinente às aspirações de qualquer político audacioso, incluindo a conquista da esposa ideal:

Não direi que Luís Alves gastasse a noite a cavar fundo no terreno das conjeturas vagas. Não era homem que perdesse tempo em coisas inúteis; e nada mais inútil naquela ocasião do que tentar explicar o que nenhuma explicação podia ter para ele. O que resolveu foi obedecer ao recado da moça; pedi-la sem hesitação nem preâmbulo. Mas se o caso lhe não produziu insônia, não deixou de lhe estender a vigília, além da hora usual, como era de jeito naquela ocasião solene, sobretudo, tratando-se de criatura que por aqueles tempos era a inveja e a cobiça de muitos olhos. ${ }^{116}$

Aqui, a prontidão em executar o que foi planejado, tanto por ele quanto por Guiomar, é evidente. O fato de ela ser desejada por outros rapazes só faz aumentar nele a vontade de efetivar o enlace. Ademais, Guiomar é bela, tem

${ }^{116}$ A mão e a luva, p. 259. 
altivez, prudência e contenção nas maneiras e nos sentimentos. A certeza de ter a companheira adequada às suas pretensões o agradava, mas não 0 extasiava. Esse passo era apenas mais um em direção ao destino agradável que a esperava. Aqui, mais uma vez, o narrador nos lembra seu estilo impassível quando comparado ao de Estevão:

A escolha estava feita, o consentimento dado. A baronesa respondeu nessa mesma tarde ao pretendente feliz. Estevão teria manifestado ruidosamente toda a alegria que semelhante resposta Ihe causara; sua alma apaixonada e exuberante contaria a Deus e aos homens aquela imensa fortuna; Luís Alves encerrou o prazer, aliás grande, dentro de si; pensou na moça e no futuro alguns instantes, mas não falou a ninguém deles. ${ }^{117}$

A contenção de Luís Alves e Guiomar contrasta frontalmente com o fervor de Julien Sorel e, até mesmo, com o de Mathilde. O trecho acima narra a quase indiferença do advogado - "pensou na moça e no futuro alguns instantes" - e o desprendimento em relação às situações afetivas. As personagens da narrativa brasileira não se permitem gastar suas energias remoendo suas dúvidas e preocupações; na francesa, ocorre o contrário, pois a força do protagonista reside justamente na insistência, quase exaustiva, do planejamento de suas ações. Esse é um dos traços do caráter extraordinário de Julien, mesmo porque a narrativa francesa explora o "grandioso". Enquanto

${ }^{117}$ Idem, p. 266. 
este precisa ter uma estratégia para realizar atos formidáveis, o deputado do romance brasileiro não se esforça muito para satisfazer o desejo de se casar com a vizinha. Como a narrativa trata da esfera doméstica, as personagens condizem com esse ambiente prosaico da corte fluminense, o que não significa ausência de amor ou falta de estratégias sociais e afetivas.

\title{
A união dos "contrários" em Le rouge et le noir
}

\begin{abstract}
Mais, ni la danse, ni le désir de plaire à un des plus jolis hommes de la cour, rien ne put distraire Mathilde; il était impossible d'avoir plus de succès. Elle était la reine du bal, elle le voyait, mais avec froideur. ${ }^{118}$
\end{abstract}

Assim, descreve o narrador, encontra-se Mlle Mathilde de La Mole antes de se apaixonar por Julien. Personagem feminina mais poderosa do romance, ela é rodeada pela sociedade mais bem composta de Paris, invejada por todas as outras mulheres, além de possuir tudo: "illustration, fortune, jeunesse"119. Não obstante, o tédio, resultante daquelas circunstâncias, acomete-a também. Num círculo de pessoas no qual todos se parecem, a semelhança, mesmo que seja de qualidades, torna-se defeito. Nesse contexto, a diferença representada por Julien transforma-se em virtude, se considerada pelo julgamento altivo da

\footnotetext{
${ }^{118}$ Le rouge et le noir, p. 610.

${ }^{119}$ Le rouge et le noir, p. 610.
} 
aristocrata. Um dos primeiros diálogos entre Julien e o grupo de Mlle de La Mole revela a discrepância existente entre eles:

(...)Mlle de La Mole lui demanda quelle pouvait être la hauteur de la montagne sur laquelle est placée la citadelle de Besançon. Jamais Julien ne put dire si cette montagne était plus pou moins haute que Montmartre. Souvent il riait de grand coeur de ce qu'on disait dans ce petit groupe; mais il se sentait incapable de rien inventer de semblable. C'était une langue étrangère qu'il eût comprise, mais qu'il n'eût pu parler. ${ }^{120}$

A primeira diferença ressaltada é a espacial. Montmartre não figura entre as referências de Julien. As diferenças entre a província, Besançon, e Paris, se estendem à disparidade cultural representada, de modo figurativo, pela linguagem. Ora, como vimos anteriormente, a capacidade de se expressar bem constitui um trunfo capital no universo dos salões parisienses. Contudo, esse desacordo, somado ao fastio de Mathilde, gera o interesse desta pelo secretário de seu pai. A atração, por parte dela, nasce justamente da incompatibilidade. Daí, iniciam-se as comparações entre Julien e Danton, que permeará toda a segunda parte do texto. Há uma insistência de associação entre as duas figuras por parte do narrador, de Mathilde e do próprio Julien como sugere o trecho abaixo:

${ }^{120}$ Idem, p. 579. 
Qui sait ce qu'on éprouve à moitié chemin d'une grande action?... Ces hautes pensées furent troublées par l'arrivée imprévue de Mlle de La Mole, qui entrait dans la bibliothèque. II était tellement animé par son admiration pour les grandes qualités de Danton, Mirabeau, de Carnot, qui ont su n'être pas vaincus, que ses yeux si ouverts s'aperçurent de as présence, son regard s'éteignit. ${ }^{121}$

Pudemos constatar a reunião, na mesma conjuntura, de Mathilde, Julien e Danton no capítulo IX da Segunda Parte. O próximo capítulo, cujo título é "La Reine Marguerite", introduz definitivamente a analogia entre Mathilde/ Reine Margot e Julien/ Danton. Stendhal escreve no "Projet d'article sur Le rouge et le noir":

Quoi qu'il en soit, Mlle de La Mole a peur, comme toute sa classe et, chose étrange, elle estime Julien parce qu'elle se figure qu'il sera un nouveau Danton. Voilà encore une des circonstances qui eût été impossible avant 1789. Un jeune pléibéien ne pouvait séduire une grande dame que par...le tempérament. ${ }^{122}$

Apesar da Restauração, a instabilidade do poder aristocrático se acentua cada vez mais até culminar na ascensão da monarquia burguesa, em julho de 1830. Há uma atmosfera de perigo iminente no decorrer da segunda

\footnotetext{
${ }^{121}$ Le rouge et le noir, p. 617.

122 STENDHAL. Ouvres romanesques complètes. Tome I. Paris, Bibliothèque de la Pléiade, Éditions Gallimard, 2005, p. 822.
} 
parte da narrativa, a partir da chegada de Julien ao Palácio de La Mole. O movimento de atração e repulsa, que conduz o envolvimento entre o protagonista e Mathilde, se deve, em boa medida, à necessidade de reconhecimento tanto dela quanto dele. Mlle de La Mole busca em Julien a energia de homens como Boniface de La Mole e Danton, enquanto ele busca nela o renome social. Dois movimentos que se alternam podem ser percebidos na formação dessa aliança improvável: a luta de dominação e o processo de reconhecimento mútuo. Segundo Jacques Dubois, a união ocorre porque eles são personagens que expressam sentimentos pungentes:

Mais c'est que l'un et autre partagent un égal mépris, Mathilde de sa classe mal restaurée et impuissante, Julien de la bourgeoisie libérale à laquelle il est promis et dont il sait que le comportement interessé prélude à bien de trahisons. Ainsi prend forme la petite société à deux dont nous avons parlé et qui prend valeur de machine de guerre tournée contre um système hypocrite de controle social. ${ }^{123}$

A estratégia de conquista das partes consiste exatamente em fazer ressaltar as diferenças. Mathilde veste o luto na data em que Boniface de La Mole foi guilhotinado, aproximando-se assim da antiga nobreza feudal. Julien percebe que ressaltar sua condição de doméstico resulta a melhor tática:

${ }^{123}$ Op. cit., p. 98. 
Mlle de La Mole a-t-elle quelque ordre à donner au secrétaire de son père? Lui dit-il; il doit écouter ses ordres et les exécuter avec respect, mais du reste, il n'a pas un mot à lui adresser. II n'est point payé pour lui communiquer ses pensées. ${ }^{124}$

De um lado, a jovem dama se apega aos tempos heróicos da França, que causam nela um sentimento misto de amor e medo, a exemplo da cena em que teme ser morta pelo amante ${ }^{125}$. Do outro, o plebeu se apaixona pela rara beleza e pelo porte nobre de Mathilde ${ }^{126}$. Resulta, dessa luta, o "amour de tête", mencionado por Stendhal no "Projet d'article sur Le rouge et le noir" , já mencionado, e resumido pelo arrivista no capítulo XVIII da Segunda Parte:

L'amour de tête a plus d'esprit sans doute que l'amour vrai, mais il n'a que des instants d'enthousiasme; il se connaît trop, il se juge sans cesse; loin d'égarer la pensée, il n'est bati qu'à force de pensées. ${ }^{127}$

Teríamos, no trecho acima, uma suspeita do que seria o desfecho da narrativa, no qual o "amour vrai" prevalecerá. Após o atentado a Madame de

\footnotetext{
${ }^{124}$ Le rouge et le noir, p. 624.

${ }^{125}$ Idem, p. 662: Julien manipula uma espada, assustando e encantando Mathilde: “J'ai donc été sur le point d'être tuée par mon amant! se disait-elle. Cette idée la trasnportait dans les plus beaux temps du siècle de Charles IX et de Henri III."

${ }^{126}$ Le rouge et le noir, p. 635.

${ }^{127}$ Le rouge et le noir, p. 670: "Cet amour n'était fondé que sur la rare beauté de Mathilde, ou plutôt, sur ses façons de reine et sa toilette admirable. En cela Julien était encore un parvenu."
} 
Rênal e os dias na prisão, a adesão à aliança se mantém só por parte de Mathilde, que se mantém consistente até o fim. Enquanto Julien começa o processo de retorno à sua essência e ao amor por Madame de Rênal, Mlle de La Mole continua a idealizar um final marcante:

Au milieu des transports les plus vifs, quand elle serrait contre son coeur la tête de Julien: Quoi! se disait-elle avec horreur, cette tête charmante serait destinée à tomber! Eh bien! ajoutait-elle enflammée d'une héroisme qui n'était pas sans bonheur, mes lèvres, qui se pressent contre ces jolis cheveux, seront glacés moins de vingt-quatre heures après. ${ }^{128}$

Mathilde tem sua satisfação definitiva com a cerimônia que promove ao enterrar a cabeça de seu amante. Com a decapitação de Julien, Mlle de La Mole tem a chance de mimetizar legitimamente seu grande modelo, a rainha Marguerite de Navarre.

\section{A união do "iguais" em A mão e a luva}

Como foi dito anteriormente, a composição dos caracteres de Guiomar e Luís Alves é feita de modo bastante parecido, suas características principais

${ }^{128}$ Idem, p. 772. 
são semelhantes e os traços de ambos se opõem aos de Estevão e, subsidiariamente, aos de Jorge.

A partir do capítulo XI, a aproximação entre os jovens se torna cada vez mais evidente. Desde o momento em que o deputado percebe as pretensões de Guiomar, a narrativa passa a intercalar as similaridades de postura dos futuros noivos. Ao refletir sobre o porquê da recusa da moça dos avanços de Estevão, o bacharel confirma sua suspeita:

Mas em que pensava ele, se não era em Estevão, nem nos autos, nem também, por agora, nas suas esperanças eleitorais? Paciência, leitor, sabê-los-ás daqui a nada. Contenta-te com a notícia de que, ao cabo de vinte minutos daquela abstração, Luís Alves volveu a si, proferindo em alta voz esta simples palavra:

_ Não há dúvida; é uma ambiciosa. ${ }^{129}$

"Ambiciosa", que num outro contexto poderia ter conotação negativa, aqui, dá força extra à personagem e ressalta sua determinação. Desse momento em diante, a convergência dos atributos das personagens se torna o assunto principal da trama. Segundo Ana Lucia Richa:

Da metade para o final do romance, o foco do narrador é cada vez mais recorrente sobre Luís Alves. Revela-se um

${ }^{129}$ A mão e a luva, p. 241. 
homem que conhece os códigos de comportamento social e sabe usá-los em seu favor, como nesta passagem: "toda a arte em suma de tratar os homens, de os atrair e de os namorar, que ele aprendera cedo e que lhe devia aproveitar mais tarde na vida pública." À inteligência vão se somando outros atributos como a observação, o cálculo, a presença de espírito e, ainda, a capacidade de dissimulação e domínio dos sentimentos. Estamos diante do espelho de Guiomar, e não poderia ser diferente, ou não seriam a mão e a luva. ${ }^{130}$

O narrador se serve inclusive do mesmo termo, utilizado para caracterizar Guiomar, na descrição de Luís Alves, de modo a pôr, lado a lado, o sentimento e o cálculo:

amor um pouco sossegado, não louco nem cego como o de Estevão, não pueril como o de Jorge, um meio-termo entre um e outro, - como podia havê-lo no coração de um ambicioso. ${ }^{131}$

Em seguida, no capítulo XVI, o narrador, para delinear o amor de Guiomar, compõe um trecho praticamente irmão do que vimos acima:

Guiomar amava deveras. Mas até que ponto era involuntário aquele sentimento? Era-o até o ponto de Ihe não desbotar à

\footnotetext{
${ }^{130}$ RICHA, Ana Lucia. "Guiomar de A mão e a luva: razão e emoção". Site www.idelberavelar.com/abralic/trabalhos/AnaLuciaRicha.doc, acessado em 23/06/2011 (ver anexo).

${ }^{131}$ A mão e a luva, p. 244.
} 
nossa heroína a castidade do coração, de lhe não diminuirmos a força de suas faculdades afetivas. Até aí só; daí por diante entrava a fria eleição do espírito. ${ }^{132}$

É esta condição dúplice da personagem que lhe confere "status" diferenciado. Em pleno romantismo brasileiro, Machado "abandona" as personagens femininas feitas de uma só feição, para inseri-las num clima de suspeição.

Simultaneamente à adesão gradual do casal, ocorre a reafirmação do romantismo iludido de Estevão e da inércia opaca de Jorge. Em contrapartida à falta de vigor desses, o narrador reafirma que a "presença de espírito de Luís Alves ia muito com o gênio de Guiomar; era um laço de simpatia." ${ }^{133}$ Aos poucos, esta percebe o "método" de seu pretendente, chegando à resolução de que ele seria o único, entre os três, que poderia proporcionar-Ihe "o espetáculo brilhante das grandezas sociais"134. O encontro das "duas ambições"135 veio suprir perfeitamente as expectativas da dupla. Ela traz a força extra que a vida política demanda e ele dá a ela o "lustre do seu nome", combinando, dessa forma, "as afeições domésticas com o ruído exterior"136.

Vimos que, em Le rouge et le noir, a atração entre Julien e Mathilde é despertada pela disputa de índoles díspares. Ele almeja, com o casamento, a

\footnotetext{
${ }^{132}$ Idem, p. 253.

${ }^{133}$ Idem, p. 245.

${ }^{134}$ Idem, p. 248.

${ }^{135}$ Idem, p. 254.

${ }^{136}$ A mão e a luva, p. 254.
} 
ascensão à mais alta nobreza; ela, por outro lado, vê, em seu amante, a possibilidade de quebrar o protocolo social estabelecido que tanto a aborrece. No romance brasileiro sucede o oposto. Guiomar é atraída por Luís Alves exatamente porque ele domina as regras e códigos sociais vigentes, destacando-se da maioria anônima, sem se configurar como um revolucionário ou figura marginal.

\section{O "desencanto final": morte}

O tema da morte traspassa toda a obra, sendo incluído, até mesmo, nas possibilidades de interpretação do título, como vimos no capítulo II deste estudo. O aparecimento desse tópico não pode ser separado, em Le rouge et le noir, de outro, que vem a ser o prenúncio. A predição do desfecho trágico surge logo no capítulo V da Primeira Parte, antes mesmo de Julien chegar à casa dos de Rênal:

Voilà le jeune homme de dix-neuf ans (...) entrait dans la magnifique église de Verrières. II la trouvait sombre et solitaire. Julien tressaillit. II portait les armes de M. de Rênal. Sur le prie-Dieu, Julien remarqua un morceau de papier imprimé, étalé là comme pour être lu. II y porta les yeux et vit:

Détails de l'exécution et des derniers moments de Louis Jenrel, exécuté à Besançon, le... 
Le papier était déchiré. Au revers on lisait les deux premiers mots d'une ligne, c'étaient: Le premier pas.

Qui a pu mettre ce papier là? dit Julien. Pauvre malheureux, ajouta-t-il avec um soupir, son nom finit comme le mien... et il froissa le papier.

En sortant, Julien crut voir du sang près du bénitier, c'était de l'eau bénite qu'on avait répandue: le reflet des rideaux rouges qui couvraient les fenêtres, la faisait paraître du sang. ${ }^{137}$

A antecipação está presente desde a primeira frase. Primeiro, temos o espaço representado pela igreja de Verrières, onde se dará o primeiro dos dias finais de Julien com o ataque à Louise de Rênal. Em seguida, ainda se tratando do meio, o preceptor lê os detalhes da execução de Louis Jenrel em Besançon, mesma cidade em que ele ficará preso e será, enfim, guilhotinado. A morte de Julien já está contida nesse papel, poi, como o protagonista nota, "Louis Jenrel” é o anagrama exato de "Julien Sorel". A expressão "Le premier pas" indica, talvez, o primeiro passo literal do condenado em direção à morte, mas também pode significar o primeiro passo de Julien em mais de um sentido. No primeiro momento, seria a entrada do ambicioso no mundo burguês, seguido pelo ingresso no aristocrático. Outra interpretação possível incidiria na alusão, mais uma vez, à sua morte ou o primeiro passo rumo a ela. A cena que se segue, na qual a água benta é confundida com sangue, prevê seu destino como também o atentado, seu ponto de partida.

${ }^{137}$ Le rouge et le noir, p. 371. 
O procedimento do prenúncio dispõe os eventos e as informações na narrativa de forma que os acontecimentos posteriores sejam preparados desde o seu início. O desfecho, quando contido já no início, promove certa unidade temática e estrutural ao texto. Segundo Jacques Dubois "le texte raconte en somme le roman par la fin, anticipant sur l'exécution finale du héros. Dès le "premier pas" de Sorel, son dernier se donne déjà à lire"138.

Vejamos outro trecho significativo do capítulo XI da Primeira Parte, em que Julien, indeciso entre as propostas concorrentes de Monsieur Valenod e Monsieur de Rênal, resolve tirar folga para espairecer nas montanhas:

Julien débout sur son grand rocher regardait le ciel, embrace par un soleil d'août. (...) Quelque épervier parti des grandes roches au-dessus de sa tête était aperçu par lui, de temps à autre, décrivant le silence ses cercles immenses. L'oeil de Julien suivait machinalement l'oiseau de proie. Ses mouvements tranquilles et puissants le frappaient, il enviait cette force, il enviait cet isolement.

C'était la destinée de Napoléon, serait-ce un jour la sienne ${ }^{139}$

Esse rochedo, lugar caro a Julien, representa as melhores sensações segundo o julgamento do herói. Seu último pedido, ao amigo Fouqué, consiste em ser

\footnotetext{
${ }^{138}$ Op. cit., p. 94.

${ }^{139}$ Le rouge et le noir, p. 406.
} 
enterrado ali ${ }^{140}$. O silêncio daquele momento antecipa também, de certa forma, aquele inerente à morte. O gavião - épervier - nos remete à águia, mencionada anteriormente, pois é também uma ave de rapina, caçadora. Por associação, o gavião alude a Julien, assim como a águia simboliza Napoleão, o que se confirmará na sentença final do trecho acima.

O fecho da morte é necessário, porque dignifica tanto Julien quanto Mathilde - "Je ne vois que la condamnation à mort qui distingue un homme, pensa Mathilde, c'est la seule chose qui ne s'achète pas"141. A aproximação final com Danton justifica ambos os percursos e os separa da mediocridade dominante:

Le comte Altamira me racontait que la veille de sa mort Danton disait avec sa grosse voix: C'est singulier, le verbe guillotiner ne peut pas se conjuguer dans tous ses temps; on peut bien dire: Je serai guillotiné, tu seras guillotiné, mais on ne dit pas: J'ai été guillotiné. ${ }^{142}$

\footnotetext{
${ }^{140}$ Le rouge et le noir, p. 804: "Qui sait? Peut-être avons-nous encore des sensations après notre mort, disait-il un jour à Fouqué. J'aimerais assez à reposer, puisque reposer est le mot, dans cette petite grotte de la grande montagne qui domine Verrières. Plusieurs fois je te l'ai conté; retiré la nuit dans cette grotte, et ma vue plongeant au loin sur les plus riches provinces de France, l'ambition a enflammé mon coeur: alors c'était ma passion... Enfin cette grotte m'est chère, et l'on ne peut disconvenir qu'elle ne soit située d'une façon à faire l'envie à l'âme d'un philosophe... (...)"

${ }^{141}$ Idem, p. 607.

${ }^{142}$ Le rouge et le noir, p. 784.
} 
Nesse instante, próximo ao final, reaparece a figura singular do Conde Altamira, personagem que, com vimos, traz o tema da condenação à morte, tanto na percepção de Mathilde quanto na de Julien. A opção pelo desfecho fatal seria a provação definitiva para contrabalançar uma história de vida carente de feitos grandiosos como os de Napoleão. ${ }^{143}$

\section{O "encanto" final: casamento}

Assim como a morte é um dos temas que permeia Le rouge et le noir, do início ao fim, o casamento constitui, em $A$ Mao e a luva, o ponto de referência para o qual se direciona a trama. Instalada na casa da madrinha e inserida na sociedade da côrte, o passo esperado na trajetória de uma moça de dezenove anos, no século XIX, conduz ao casamento. Esse fim, a união de Guiomar, está previsto e dado na narrativa, não sendo uma dúvida para o leitor. $O$ questionamento se concentra na escolha do noivo, ou melhor, no acordo da vontade da jovem e o consentimento da baronesa, ou seja, no arranjo que não infelicita a pobreza, nem estigmatiza a riqueza. É sempre interessante notar que Guiomar possibilita à madrinha o consentimento e, ao mesmo tempo, recria a ilusão da maternidade na velha senhora.

\footnotetext{
${ }^{143}$ Segundo Jacques Dubois, Julien tem a necessidade de acumular pequenas auto-provações que compensem a falta de uma história lancinante. Op. cit., p. 51.
} 
Pretendida por três rapazes, Estevão, Jorge e Luís Alves, a possibilidade concreta repousa somente nos dois últimos. Demasiado sentimental e desprovido de pulso firme perante a vida profissional e social, Estevão é o primeiro a ser veementemente descartado. A vida puramente sentimental que poderia oferecer não seria satisfatória. Restando Jorge e Luís Alves, este corresponde às expectativas elevadas de Guiomar frente à placidez e à falta de energia do sobrinho da madrinha:

O proceder de Luís Alves, sóbrio, direto, resoluto, sem desfalecimentos, nem demasias ociosas, fazia perceber à moça que ele nascera para vencer e sua ambição tinha verdadeiramente asas, ao mesmo tempo, que as tinha ou parecia tê-las o coração. Demais, o primeiro passo do homem público estava dado; ele ia entrar em cheio na estrada que leva os fortes à glória. Em torno dele ia fazer-se aquela luz, que era a ambição da moça, a atmosfera, que ela almeja respirar. ${ }^{144}$

Decidida por aquele que "Ihe falava ao coração", a dificuldade de Guiomar se resume em corresponder a sua pretensão, não causando, no entanto, nenhum tipo de aborrecimento à sua provedora. Hábil e astuta, ela diz, com grande pesar, que prefere o sobrinho. Essa tática se mostra eficaz, pois transparece aos olhos da baronesa a verdadeira intenção da jovem, ao mesmo tempo em que coloca o respeito em relação à vontade da senhora em primazia.

${ }^{144}$ A mão e a luva, p. 254. 
Desse modo, como o próprio narrador aponta, quem dá a palavra final, mesmo que seguindo o intento da afilhada, é a madrinha (sucedâneo da "mãe"):

Vê o leitor que a palavra esperada, a palavra que a moça sentia vir-Ihe do coração aos lábios e querer rompê-los, não foi ela quem a proferiu, foi a madrinha; e se leu atento o que precede verá que era isso mesmo que ela desejava. ${ }^{145}$

O capítulo final, que tem como título "Conclusão", resume a narrativa retomando seu fio condutor, que vem a ser a junção da vontade do coração e a vantagem social. A descrição da chácara no dia do casamento funciona como metáfora das personagens em questão:

A manhã daquele dia trajava um manto de neblina cerrada, que o nosso inverno the pôs aos ombros, como para resguardá-la do rigor benigno da temperatura, manto que ela sacudiu dali a nada, a fim de se mostrar qual era, uma deliciosa e fresca manhã fluminense. Não tardou que o sol batesse de chapa nas águas tranqüilas e azuis, e nessas colinas onde 0 verde natural ia alternando com a alvura das habitações humanas. Vento nenhum; apenas uma aragem, branda e fresca, que parecia o último respirar da noite já remota, e que só a trechos agitava as folhas do arvoredo. ${ }^{146}$

\footnotetext{
${ }^{145}$ A mão e a luva, p. 265.

${ }^{146}$ Idem, p. 268.
} 
Esta passagem que, a princípio, dá a impressão de descrever a atmosfera bucólica da cerimônia, revela as características centrais de Guiomar e Luís Alves, como se os traços humanos se fundissem impecavelmente à natureza. O paradoxo "rigor benigno da temperatura" parece ter função de absolver o possível rigor da constituição da dupla, elevando-o como qualidade. As "águas tranqüilas" e a "aragem branda e fresca" remetem ao comedimento do casal, à escolha de vida que foi pensada e desejada levando sempre em consideração as questões práticas. Não testemunhamos paixão violenta e desmedida, apenas um amor sensato e senhor de si, nem por isso menos digno ou verdadeiro. Mais uma vez é bom ressaltar que, tal como em Ressurreição, Machado busca estabelecer os contornos de caracteres, sem os excessos românticos. Vimos que a evolução de Guiomar, na trama, depende da de Luís Alves e vice-versa, de modo que a construção deles toma forma especular. Por outro lado, Estevão e Jorge assumem posição de contraponto, o que faz com que a semelhança dos noivos se torne ainda mais evidente. Um dos últimos parágrafos do romance corrobora a decisão certeira da jovem arrivista:

O destino não devia mentir nem mentiu à ambição de Luís Alves. Guiomar acertara; era aquele o homem forte. Um mês depois de casados, como eles estivessem a conversar do que conversam os recém-casados, que é de si mesmos, e a relembrar a curta campanha do namoro, Guiomar confessou ao 
marido que naquela ocasião lhe conhecera todo o poder da sua vontade. ${ }^{147}$

${ }^{147}$ A mão e a luva, p. 270. 


\section{Conclusão}

O arrivismo social, tratado em Le rouge et le noir, passa a ser um dos grandes temas da literatura francesa no século XIX, sobretudo a partir de Stendhal e Balzac. A conjuntura sócio-política da França, naquele momento, constitui matéria fértil a ser representada artisticamente. A possibilidade de mobilidade social - pós-Revolução e corroborada pelo Império de Napoleão encontra resistência na Restauração; no entanto, os salões nobres tornam-se cada vez mais heterogêneos, recebendo e tolerando as mais diversas figuras. O percurso de Julien Sorel só é possível graças a essas profundas mudanças ocorridas em um curto período naquele país.

No caso de $A$ mão e a luva, temos uma narrativa que se passa em um dos períodos mais estáveis do Segundo Reinado, fazendo com que seu interesse se desloque para a especificidade doméstica, na qual a narrativa se concentra. Guiomar transita em um espaço muito restrito, típico da sociedade fluminense na côrte. $O$ interesse de se analisar comparativamente o tema nessas duas obras reside justamente em observar como ele pode ser abordado em contextos tão díspares, geográfica e socialmente.

Sendo a literatura uma das artes que mais se alimenta de si mesma, é natural que haja semelhanças entre as duas obras, especialmente porque ambas pertecem ao século XIX e põem em seu centro o mesmo assunto. Contudo, as diferenças são inevitáveis, pois como dissemos anteriormente, a conjuntura específica de cada obra influencia diretamente sua composição. 
Além disso, é fundamental ressaltar que o texto francês escolhe um protagonista masculino, enquanto o brasileiro opta por privilegiar o percurso de uma mulher.

As semelhanças de Julien Sorel e Guiomar confluem, sobretudo, nos anos de formação da infância e adolescência. Dotados de uma inteligência acima da média, têm grande capacitadade de se adaptar às novas situações que surgem. Julien e Guiomar ajustam-se com facilidade às casas em que são recebidos, de maneira que podem "promover" o projeto de ascensão e manutenção da nova posição.

A falta de adequação ao ambiente de origem também constitui um ponto comum às duas histórias. Atraídos, desde muito cedo, por elementos que simbolizam uma vida de prestígio - Julien, pelo uniforme militar e Guiomar, pelas jóias das moças vizinhas - os protagonistas se empenham, com notável determinação, em destacar-se entre os que estão à sua volta. O herói francês ofusca as outras personagens masculinas em todos os meios nos quais se insere, enquanto a protagonista do romance brasileiro conquista lugar soberano na casa da baronesa e desperta desejo nos homens, além da inveja em mulheres.

Apontadas as principais similaridades entre as obras, passemos às especifidades de cada uma, pois, a partir delas, conseguimos delinear as particularidades nacionais dos romances. Le rouge et le noir retrata diferentes níveis da organização social francesa à época, de maneira que nos permite transitar pelas mais diversas situações. Através do caráter e da percepção de 
um herói excepcional, apreendemos os jogos de interesses da burguesia, do clero e da alta nobreza. Os feitos de Julien são extraordinários, possibilitando uma ascensão incomum naquele contexto. A união com Mathilde de La Mole eleva-o a uma posição única que o aproxima de figuras míticas, sobretudo de Danton. O final glorioso alça o jovem de origem camponesa a um status quase mítico, fazendo desaparecer sua história carente de antepassados e feitos grandiosos.

No caso de Guiomar, temos um cenário bem distinto. Em uma cidade como o Rio de Janeiro, sob o Império estável de D. Pedro II, a trama se concentra no âmbito doméstico, no qual a observação do universo feminino é suficiente para se desvendarem as nuances dessa sociedade. A personagem já se encontra na capital do país que, mesmo ocupando posição central, ainda cultiva, em seu dia-a-dia, hábitos bastante provincianos. Seu campo de ação consiste, apenas, na casa onde vive. Ela precisa fazer-se notar, sem, no entanto, expor-se demasiadamente. Assim, sua estratégia de ação fica muito restrita. Guiomar conhece os três pretendentes em sua própria moradia, ou seja, na mansão da baronesa, e tem somente esse espaço para analisá-los e escolher o que mais se adequa às suas aspirações. Sua atitude mais ousada, no decorrer de todo o romance, é deixar a carta ordenatória na casa de Luís Alves. Esse ato arrojado só é realizado, no entanto, após o favorito ter se declarado a ela, assegurando-lhe sustentar o compromisso, caso ela o aceitasse.

Enquanto a narrativa francesa precisa se expandir espacialmente para retratar as mudanças importantes que vêm ocorrendo em seu território, a 
brasileira se volta para o prosaico que traduz, em boa medida, o modo de vida daquele grupo.

O resultado artístico das obras parece corresponder satisfatoriamente às suas realidades. O romance de Stendhal representa uma faceta importante dessa Paris, que, nas palavras de Walter Benjamin, era a capital do século XIX. Por outro lado, o texto de Machado busca o tema do arrivismo dimensionandoo à relevância brasileira. Julien Sorel se eleva a uma posição nobre com a recusa de apelar contrar a sentença de morte, transparecendo, assim, sua escolha final em direção à busca pelo sentimento verdadeiro. Em contapartida à desistência dele, temos a afirmação da ascensão de Guiomar, concretizado pelo casamento ideal. Enquanto em Stendhal observamos uma narrativa do "grandioso", que envolve figuras influentes na esfera nacional, em Machado verificamos a construção de uma trama na qual uma moça de origem humilde conquista estabilidade e "lustre" dentro do pequeno domínio que conhece. 0 romancista brasileiro foge ao estereótipo da moça fútil ou volúvel ao mesmo tempo em que se distancia do melodramático de Senhora, de José de Alencar, escrito à mesma época. É interessante ressaltar também que a narrativa francesa revela a busca pela personagem de exceção, inconformada com o sistema estabelecido; a brasileira, ao contrário, procura a identificação equilibrada entre seres que conhecem e apreciam as normas instituídas, além de compartilharem as mesmas ambições.

Com o empreendimento da leitura paralela das obras, pudemos, não somente assinalar os pontos comuns, como também aprofundar mais seus traços específicos. Temos a esperança de que venha a se somar ao estudo 
das histórias literárias francesa e brasileira, às suas particularidades e, também, às suas férteis relações culturais e literárias. 


\section{Bibliografia}

\section{I) Machadiana:}

ASSIS, Joaquim Maria Machado de. Obra completa. Tomo I. Editora Nova Aguilar : Rio de Janeiro, 1959.

BOSI, Alfredo et alli. Machado de Assis, São Paulo: Ática, 1982.

PASSOS, Gilberto Pinheiro. A Poética do Legado : presença francesa em Memórias Póstumas de Brás Cubas. São Paulo: Annablume, 1996.

PASSOS, Gilberto Pinheiro. O Napoleão de Botafogo : presença francesa em Quincas Borba de Machado de Assis. São Paulo: Annablume, 2000.

PEREIRA, Lúcia Miguel. Machado de Assis : estudo crítico e biográfico. Belo Horizonte: Editora Itatiaia, 1988.

RICHA, Ana Lucia. "Guiomar de $A$ mão e a luva: razão e emoção". Site www.idelberavelar.com/abralic/trabalhos/AnaLuciaRicha.doc, acessado em 23/06/2011. (Ver anexo)

SCHWARZ, Roberto. Ao vencedor as batatas. São Paulo, Editora 34, 1997/ $5^{\text {a }}$ Ed. 2000.

STEIN, Ingrid. Figuras femininas em Machado de Assis. Rio de Janeiro, Paz e Terra, 1984.

II) Stendhaliana:

BROMBERT, Victor. Stendhal roman et liberté. Paris, Editions de Fallois, 1991. 
CROUZET, Michel. Le rouge te le noir. Essai sur le romanesque stendhalien. Paris : PUF, 1995.

DUBOIS, Jacques. Stendhal une sociologie romanesque. Paris : Éditions La Découverte, 2007.

GUÉRIN, Michel. La grande dispute: essai sur l'ambition, Stendhal et le XIXe siècle. Paris : Actes Sud, 2006.

REY, Pierre Louis. Le rouge et le noir. Paris, Ellipses, 2002, Col. Les textes fondateurs.

RUDE, Fernand. Stendhal et la pensée sociale de son temps. Brionne : Gérard Monford Éditeur, 1983.

STENDHAL. Oeuvres romanesques complètes. Tome I. Paris: Bibliothèque de La Pléiade : Éditions Gallimard, 2005.

VÁRIOS. La création romanesque chez Stendhal / Actes du XVlème Congrès International Stendhalien. Paris, 26-29 avril 1983, Genève, Librairie Droz, 1985.

\section{III) Teoria literária e literatura comparada:}

AUERBACH, Erich. Mimesis. São Paulo, Perspectiva, 2002.

BRUNEL et alli. Que é literatura comparada? São Paulo: Perspectiva, 1970.

BRUNEL, P. \& CHEVREL, Y. Précis de littérature comparée. Paris, Presses Universitaires de France, 1989.

CANDIDO, Antonio. Literatura e sociedade. São Paulo: Companhia Editora Nacional, 1975. 4를.

CARVALHAL, Tania F. Literatura comparada. São Paulo: Editora Ática, 2006. 
CHEVREL, Yves. La littérature comparée. Paris : PUF, 5ème édition refondue, 2006.

CLAUDON, F. \& HADDAD-WOTLING, K. Précis de littérature comparée. Paris : Armand Colin, 1992.

HAUSER, Arnold. História social da arte e da literatura. São Paulo, Martins Fontes, 2003.

KAYSER,W. Introdução à literatura comparada. Lisboa: Calouste Gulbenhan, 1989.

MACHADO, A. M. \& PAGEAUX, D-H. Da literatura comparada à teoria da literatura. Lisboa: Edições 70, 1988.

POULET, Georges. Trois essais de mythologie romantique. Saint-Brieuc, Librairie José Corti, 1966.

WELLEK, R. \& WARREN, A. Teoria da literatura e metodologia dos estudos literários. São Paulo: Martins Fontes, 2003.

IV) História:

ALENCASTRO, Luiz Felipe de. NOVAIS, Fernando A. História da vida privada no Brasil Vol. 2. Império: $A$ corte e a modernidade nacional. São Paulo: Companhia das letras, 1997.

BERNARDES, Maria Thereza C. C. Mulheres de ontem? Rio de Janeiro Século XIX. São Paulo: T. A. Queiroz Editor, 1989.

CHARLE, Christophe. Histoire sociale de la France au XIXe siècle. Paris, Éditions du Seuil, 1991.

DÉMIER, Francis. La France du XIXe siècle. Paris, Éditions du Seuil, 2000. 
FRANCO, Maria Sylvia de Carvalho. Homens livres na ordem escravocrata. São Paulo: Unesp, 1997.

GOUBERT, Pierre. História Concisa de França. Volume II. Portugal: EuropaAmérica, 1996.

HOLANDA, Sérgio Buarque de. História Geral da Civilização Brasileira Vol. 5. O Brasil monárquico: reações e transações. São Paulo: Bertrand Brasil, 2004.

MAYEUR, Françoise. Histoire générale de l'enseignement et de l'éducation em France, 1789-1830 Tome 3. Perrin, 2003.

SAFFIOTI, Heleieth I. B. A mulher na sociedade de classes: mito e realidade. Petrópolis: Vozes, 1979.

\section{V) Outras fontes:}

ALENCAR, José de. Senhora/ Iracema. São Paulo, Editora Scipione, 1994.

BALZAC, Honoré de. La Comédie Humaine III. Paris, Bibliothèque de La Pléiade/ Éditions Gallimard, 1976.

. La Comédie Humaine V. Paris, Bibliothèque de La

Pléiade/ Éditions Gallimard, 1977.

BEAUMARCHAIS. Le mariage de Figaro / Le Barbier de Séville. Paris, Classiques Français, 1995.

Le Petit Nouveau Robert, Paris, Dictionnaires Le Robert, 1967. 


\section{Anexo \\ Guiomar de A mão e a luva: razão e emoção}

\section{Ana Lúcia Richa}

As relações amorosas, com suas incríveis peripécias de conquistas e casamentos envolvendo complicadas tramas sentimentais, sociais, políticas e econômicas, estão entre os temas mais recorrentes da literatura. Neste universo, as inclinações do coração nem sempre estão em primeiro plano, especialmente para a mulher, que, apesar de ter sua imagem culturalmente ligada, entre outras coisas, à emocionalidade, à submissão e à modéstia, tradicionalmente encontra possibilidades de colocação social justamente no casamento.

Enquanto o tema se repete e as histórias se aproximam, as sucessivas gerações trazem novas abordagens, novas implicações para os conflitos, novos ambientes e personagens e, principalmente, novas soluções narrativas. O embate entre o casamento definido pela escolha amorosa ou racional esteve em foco na trama de $A$ mão e a Luva, criada por Machado de Assis, e será observada neste estudo, assim como sua construção narrativa. Também será observada a proximidade deste romance com $A$ princesa de Clèves, escrito dois séculos antes por Madame de Lafayette.

A mão e a luva é o segundo romance de Machado de Assis. Foi publicado em vinte folhetins em $O$ Globo, no Rio de Janeiro, entre 26 de setembro a 3 de novembro de 1874. Em dezembro deste mesmo ano, apareceu publicado em livro e trazia na Advertência uma ressalva do autor comentando o padecimento do estilo com um método sujeito às urgências da publicação diária, "um pouco fora dos hábitos do autor"1..

De acordo com Ubiratan Machado, no livro Machado de Assis: roteiro de consagração, a repercussão foi menor que a de Ressurreição, contando apenas com algumas notas, duas breves resenhas sem assinatura, em Vida Fluminense,

\footnotetext{
${ }^{1}$ Machado de Assis. A mão e a luva. Rio de Janeiro/Brasília: Civilização Brasileira/INL, 1975, p. 57.
} 
e uma crítica feita por Araucarius, pseudônimo do cônego Fernandes Pinheiro, em O Novo Mundo ${ }^{2}$. Machado de Assis já gozava de certo prestígio quando escreveu A mão e a luva: em 1867, recebera a Ordem da Rosa, no grau de cavaleiro, era ajudante do diretor do Diário Oficial e chefe da seção da Secretaria de Agricultura como primeiro-oficial.

Apesar de ser tratado como o segundo romance do autor, vale ressaltar que, na "Advertência de 1874", o autor classifica a obra como novela, provavelmente em razão do tamanho e da limitação do objeto ao desenho de alguns caracteres, como ele mesmo admite. Nas palavras do autor: "Convém dizer que o desenho de tais caracteres, - o de Guiomar, sobretudo, - foi o meu objeto principal, se não exclusivo, servindo-me a ação apenas de tela em que lancei os contornos dos perfis. Incompletos embora, terão saído naturais e verdadeiros?"3 Em $A$ mão e a luva, Machado continua a explorar o romance como espaço de contraste de caracteres, como fez em Ressurreição e deixou explícito na advertência da primeira edição: "Não quis fazer romance de costumes; tentei o esboço de uma situação e o contraste de dous caracteres;(...)"4

Seguimos a preocupação do autor em $A$ mão e a luva, por isso, neste ensaio, desejamos identificar as várias facetas de Guiomar. Facetas muitas vezes contraditórias, porque, ao invés de um narrador distanciado, encontramos um narrador que assume a perspectiva dos pretendentes da moça para apresentá-la. E ainda, ao final da trama, abre espaço para que a própria heroína se descreva. Neste trabalho, portanto, pretendemos acompanhar o percurso narrativo que conduz às diversas formas de apresentação da personagem Guiomar durante o momento decisivo de sua via, a escolha de um marido.

\section{Guiomar e as mulheres de Machado}

\footnotetext{
${ }^{2}$ Ubiratan Machado. Machado de Assis: roteiro da consagração. Rio de Janeiro: EdUERJ, 2003, p. 14.

${ }^{3}$ Machado de Assis. op. cit., 1975, p. 57.

${ }^{4}$ Machado de Assis. Ressurreição. Rio de Janeiro/Brasília: Civilização Brasileira/INL, 1975, p. 61.
} 
Machado de Assis recua 20 anos para contar a história de $A$ mão e a luva que começa em 1853. Nessa época, já havia sido declarada a maioridade de Pedro II e o Brasil vive um período de paz interna e construção nacional. Entretanto, a política não é tratada senão como tema incidental na candidatura de Luís Alves e nas suas perspectivas de ascensão social.

O clima de $A$ mão e a luva, como nos outros romances, é o das camadas mais altas da sociedade, instalada em bairros nobres como Botafogo. A vida social aparece com as vantagens e os divertimentos da corte, teatros e reuniões familiares, o desfrutar das chácaras, as leituras em voga, um pouco de piano e o chiquismo da rua do Ouvidor.

Guiomar, personagem principal do romance, é uma jovem de origem humilde que depois da morte dos pais foi adotada pela madrinha, uma baronesa viúva. O breve romance gira em torno da definição do casamento da heroína que deve escolher entre três pretendentes: o primeiro é Estevão, rapaz romântico e fraco; o segundo é Jorge, jovem sem muita expressão e sobrinho da baronesa, a quem Guiomar deve sua posição social; o terceiro é Luís Alves, homem forte e ambicioso que arrebata o coração da moça. Além deles, participa da trama Mrs. Oswald, viúva inglesa que é dama de companhia da baronesa. Longe da romântica escolha motivada pelo amor, Machado trouxe para este romance o jogo de interesses do casamento, que não envolve somente as partes, mas principalmente os familiares e agregados.

Ingrid Stein, no livro Figuras femininas em Machado de Assis, destaca que o casamento na segunda metade do século XIX representava a maior aspiração para a maior parte das moças, já que era a única chance de obtenção de um status social mais elevado. É relevante observar que a esfera de poder de decisão e a influência feminina estavam restritas quase que exclusivamente a casa, inclusive a possibilidade de realização da mulher ocorria majoritariamente através de seu marido e filhos. Dessa forma, o casamento era um evento essencial na vida da mulher, através do qual ela conseguia status e função social.

Therezinha Mucci Xavier, no livro A personagem feminina do romance de Machado de Assis, chama atenção para que não se encontra, com raras 
exceções, nas personagens femininas machadianas o amor grato, devoto e puro. laiá, Guiomar, Virgília, a adúltera, Sofia, a faceira, e Capitu, de honra duvidosa, todas essas mulheres têm um ponto de contato, o egoísmo, que não lhes permite amar desprendidamente.

O egoísmo das figuras femininas de Machado de Assis está intrinsecamente ligado à luta de querer elevar-se, à ambição da mulher, muitas vezes vinda do meio humilde, de fixar-se na burguesia. Daí o egoísmo também direcionar os casamentos, muitas vezes pragmatistas e decididos futilmente, mas estritamente indispensável à realização plena da mulher ${ }^{5}$.

Os pretendentes de Guiomar, como os homens da época, tinham possibilidades de ascensão pelos próprios meios. Estevão estuda Direito e, em seguida, se torna advogado. Jorge tem a possibilidade de fazer carreira pública graças ao nome deixado pelo pai e à influência da tia, mas vive usufruindo a vida de herdeiro. Luís Alves é advogado e caminha para uma carreira pública. Ao contrário da situação da mulher, o casamento para o homem, embora fosse aconselhável, não tinha importância vital.

Guiomar cogita ser professora, porque, como mulher sem bens, não se casando, teria de trabalhar para se sustentar. Guiomar encara essa necessidade com vergonha. É com acanhamento que comunica à madrinha a necessidade de trabalhar:

- (...) mas a cada qual cabe uma obrigação, que se deve cumprir. A minha é...é ganhar o pão.

Estas últimas palavras passaram-lhe pelos lábios como que à força. O rubor subiuIhe às faces; dissera-se que a alma cobria o rosto com vergonha ${ }^{6}$.

O narrador assinala que isso representava para Guiomar sujeitar-se à mediocridade. Entretanto, não descartamos o calculo da moça que declaradamente contava com a ternura da madrinha. Therezinha Mucci Xavier, ressalta que o acanhamento de Guiomar está em acordo com o contexto da

\footnotetext{
${ }^{5}$ Therezinha Mucci Xavier. A personagem feminina no romance de Machado de Assis. Rio de Janeiro: Presença, 1986, p. 50.

${ }^{6}$ Machado de Assis. A mão e a luva. Rio de Janeiro/Brasília: Civilização Brasileira/INL, 1975, p. 83.
} 
mulher da época que tinha a sua participação na vida econômica considerada como um desvio do normal, como uma infração da ordem natural das cosas. Entretanto, se as mulheres da classe alta, que são quase todas as personagens principais de machado, tinham sua atuação ligadas à vida doméstica e social, o mesmo não ocorria com as mulheres das camadas mais baixas. Além do exemplo da Guiomar na infância e juventude, temos a Mrs Oswald que trabalha para a baronesa, em Memórias Póstumas de Brás Cubas, temos D. Plácida.

Para Guiomar, era uma opção que a envergonharia, mas, para Luís Garcia, de laiá Garcia, dar uma profissão à filha, mestra de piano, era o melhor que poderia fazer para garantir seu futuro. A formação intelectual parece não ser uma prioridade entre as personagens principais de Machado. Therezinha Mucci Xavier defende que a preocupação em dar uma profissão às filhas era das famílias que tinham que lutar pela subsistência. Assim mesmo, o magistério era quase que a única opção considerada digna para as moças.

Guiomar, de A mão e a luva, aspira a ser professora como meio de subsistência. Sua mãe, que mal lhe ensinou ler escrever, ambicionava vê-la médica: "hás de ser a minha doutora". Com a morte de Henriqueta (filha da baronesa), Guiomar estabelece-se na casa da madrinha, não mais se preocupando com aprimoramento intelectual, bastando-Ihe as atividades artísticas: tocar piano, ler romances. O que ela cobiçava era o luxo, o lustre de seu nome, os quais poderiam fazê-la, mais que a ciência, triunfar. É interessante notar como o autor faz uma de suas personagens despertar a ambição de uma carreira médica para sua filha, como a mãe de Guiomar, se as mulheres de nosso país tiveram somente acesso aos estudos de medicina cinco anos após a publicação do romance. O ideal de professora, todavia, era mais fácil de se alcançar, pois já haviam sido instaladas as primeiras Escolas Normais (1835, em Niterói; 1836, na Bahia; 1846, em São Paulo) $)^{7}$.

Vale lembrar que o primeiros romance de Machado de Assis é publicado em 1872 e o último, em 1908. Nesses 36 anos, passando os olhos pelas principais personagens femininas dos nove romances, constata-se uma mínima variação de suas atividades. Em Ressurreição, Cecília, Raquel e Lívia se ocupavam com tocar piano, ler, ir ao teatro e outros divertimentos e eventos sociais. Guiomar, Mrs Oswald e a baronesa de $A$ mão e a luva tinham ocupações semelhantes. No

\footnotetext{
${ }^{7}$ Therezinha Mucci Xavier. Op. cit., p. 27.
} 
terceiro romance, encontramos duas personagens antagônicas: Helena, a protagonista, era laboriosa, culta e prendada, assumiu a casa quando D. Úrsula ficou doente, lia e desenhava com arte; ao passo que Eugênia gastava seu tempo tocando piano, indo a teatros e bailes. Em laiá Garcia, Luís Garcia possuía meios para isentar laiá e Estela da luta pela sobrevivência e Valéria era uma viúva rica.

Nos romances da segunda fase, não existe mudança significativa. Em Memórias Póstumas de Brás Cubas, apesar de Marcela e D. Plácida precisarem trabalhar, Virgília, que é a personagem feminina principal, é apresentada como “(...) ignorante, pueril, cheia de uns ímpetos misteriosos; muita preguiça (...)". Em Quincas Borba, Sofia só valoriza teatros, passeios, vestidos, jóias e compras. Capitu é tratada mais na infância, as vê-se que sua mãe, D. Fortunata, se dedica a casa. A condição de viúva de D. Glória, mãe de Bentinho, faz com que ela seja a administradora dos bens da família - como a baronesa, madrinha de Guiomar. Em Esaú e Jacó, Flora, Natividade, D. Cláudia e Perpétua não têm atividades que as diferenciem das anteriores. D. Carmo, de Memorial de Aires, se dedica aos filhos postiços enquanto Fidélia gasta seu tempo com o piano e a pintura.

Dessa forma, a saída de Guiomar do colégio e o preenchimento de seu tempo com o piano, com a leitura de romances, com os passeios e os eventos sociais marcam sua passagem para a classe social alta, em que ela, mesmo depois do casamento, deseja se manter. Ingrid Stein classifica diversas personagens femininas dos romances de Machado como sendo extremamente ambiciosas; Guiomar pertence ao grupo. Contudo, a pesquisadora ressalva que essas personagens, como a maior parte das mulheres da segunda metade do século XIX, não têm a possibilidade de realizar por si só suas aspirações, elas convergem suas próprias ambições e energias para a carreira de seus maridos, filhos e até amantes. Apesar de jovem, Guiomar é perspicaz o bastante para saber que a melhor maneira de realizar sua ambição de sucesso social seria através de um casamento adequado. Percebe que Estevão não Ihe daria mais que a

\footnotetext{
${ }^{8}$ Machado de Assis. Memórias póstumas de Brás Cubas. Rio de Janeiro/Brasília: Civilização Brasileira/INL, 1977, p. 152.
} 
promessa de uma vida sentimental, ao passo que Jorge não oferecia mais que uma vida "vegetativa". Entretanto, Luís Alves:

fazia perceber à moça que ele nascera para vencer e que a sua ambição tinha verdadeiramente asas, ao mesmo tempo que as tinha ou parecia tê-las o coração. Demais, o primeiro passo do homem público estava dado; ele ia entrar em cheio na estrada que leva os fortes à glória. Em torno dele ia fazer-se aquela luz, que era a ambição da moça, a atmosfera, que ela almejava respirar ${ }^{9}$.

Nas palavras do narrador novamente: "Ela queria um homem que, ao pé de um coração juvenil e capaz de amar, sentisse dentro em si a força bastante para subi-la aonde a vissem todos os olhos."10 A ascensão social e política de Luís Alves seria também a de Guiomar como sua esposa. Acompanhando o raciocínio de Ingrid Stein, "era o auge do que uma mulher poderia almejar."11

Este é um assunto que retorna em outras obras do autor. Em Memórias póstumas de Brás Cubas, Virgília pede ao noivo que a faça baronesa e ele a promete fazê-la marquesa. Virgília se realizaria inclusive através do amante Brás Cubas que decide cuidar da carreira política e um dos motivos é justamente fazer Virgília “(...) ufanar-se quando visse luzir o meu nome..."12. Em Quincas Borba, Sofia usa de todos os meios para atrair Rubião e seduzi-lo a continuar apoiando os empreendimentos de seu marido, Cristiano Palha. Natividade, de Esaú e Jacó, é presenteada pelo marido, ao completar quarenta anos, com o título de baronesa. E para Natividade, inclusive os filhos são veículos para sua realização. O narrador não deixa de apontar sua reação de felicidade à esperança de que os filhos fossem "grandes", depois da previsão da cabocla. No mesmo livro, vê-se D. Cláudia, agindo com determinação para alcançar a glória política do marido, participando de suas decisões e usando inclusive o baile da ilha como oportunidade de promovê-lo. Até Helena, que não pode ser considerada

\footnotetext{
${ }^{9}$ Machado de Assis. A mão e a luva. Rio de Janeiro/Brasília: Civilização Brasileira/INL, 1975, p. 138.

${ }^{10}$ Idem, p. 130.

${ }^{11}$ Ingrid Stein. Figuras Femininas em Machado de Assis. Rio de Janeiro: Paz e Terra, 1984, p. 66.

12 Machado de Assis. Memórias póstumas de Brás Cubas. Rio de Janeiro/Brasília: Civilização Brasileira/INL, 1977, p. 242.
} 
ambiciosa, é capaz de dizer: "O casamento não é uma solução, penso eu; é um ponto de partida. O marido fará a mulher."13

Não apenas a mulher dependia deste jogo: afinal, desde muito tempo, o casamento se tornou a mais estável forma de realização de alianças, especialmente políticas e econômicas. Portanto, todo o grupo social participava ativamente do agenciamento das uniões. Machado de Assis, ao tratar do casamento de Guiomar, não despreza os diversos desejos e interesses das outras personagens envolvidas na trama. Da parte de Guiomar, vemos que era ambiciosa e que desejava gozar da distinção social; entretanto, para ela, pesava tanto ou mais a necessidade do rompimento de sua situação de agregada, tanto que sente repulsa à idéia de se ver obrigada a casar com o sobrinho da baronesa. Portanto, todos os cálculos de Guiomar eram no sentido de, através do casamento com Luís Alves, superar a relação de favor implícita em sua associação com a baronesa, que seria mantida no casamento com Jorge. Guiomar tenta manter seu status, mesmo independente da baronesa. O caminho era unir-se a Luís Alves: ela precisava do lustre do seu nome ${ }^{14}$.

O advogado, por sua vez, além de amar à sua maneira, contava com Guiomar como uma "força nova"15, já que ser bem casado, ou melhor, parecer bem casado era essencial para um homem que entrara para a vida pública. Jorge tendia para o gosto da união com uma esposa bela e querida, mas não esquecia a conveniência da não divisão da herança da tia, afinal "possuir era seu único ofício" ${ }^{\prime 16}$. Estevão transformara Guiomar em seu objetivo de vida, sem atentar para a falta de inclinação da moça para ele e muito menos para o fato de pertencer a uma outra esfera social - a moça tornou-se inatingível para ele no momento em que foi considerada filha da baronesa.

\footnotetext{
${ }^{13}$ Machado de Assis. Helena. Rio de Janeiro/Brasília: Civilização Brasileira/INL, 1975, p. 104.

${ }^{14}$ Machado de Assis. A mão e a luva. Rio de Janeiro/Brasília: Civilização Brasileira/INL, 1975, p. 162.

15 Idem, p. 162.

${ }^{16}$ Ibidem, p. 131.
} 
Depois dos pretendentes, a mais interessada na articulação que levaria ao casamento de Guiomar era Mrs. Oswald. Talvez ela estivesse mais envolvida com o jogo do que a própria madrinha da moça. A baronesa era a única realmente guiada apenas pelo coração, seu desejo era a felicidade da afilhada e do sobrinho. A união dos dois Ihe traria felicidade apenas na medida em que acreditava no amor entre eles. Tal esperança era alimentada por Mrs. Oswald. A inglesa, sim, tinha razões que ultrapassavam o carinho por Guiomar, a amizade e a gratidão à família. A inglesa não tinha qualquer interesse pecuniário; por outro lado, a demonstração de sagacidade e habilidade para exercer uma "diplomacia doméstica"17, que resultasse no desfecho feliz de uma operação delicada, era a chance de conseguir o reconhecimento, a gratidão e o estreitamento dos laços com a baronesa - ponto essencial na sua condição de agregada, ainda inferior à situação de Guiomar.

Percebemos, então, que, na pintura do caráter de Guiomar, Machado não economizou na tinta da ambição nem da inteligência, tampouco da força. Apesar de ser jovem, Guiomar possui uma grande capacidade de percepção da realidade e muita vontade e empenho no sentido de atingir seus objetivos. O que faz $\mathrm{H}$. Pereira da Silva criticar o excesso de maturidade do pensamento da moça ${ }^{18} \mathrm{e}$ Agrippino Grieco não entender o amor de Guiomar nascido do cálculo ${ }^{19}$.

É preciso notar que uma grande parte das personagens femininas de Machado de Assis apresenta uma postura altiva em relação às masculinas e, principalmente, demonstram certo empenho em realizar sua vontade. De acordo com Therezinha Mucci Xavier, no livro A personagem feminina no romance de Machado de Assis:

\footnotetext{
${ }^{17}$ Idem, p. 128.

18 "Guiomar pensa com muita maturidade. Faz lembrar Helena que, com dezesseis anos, encontra uma definição para o medo, superior a de qualquer grande psicólogo (...)”. (H. Pereira da Silva. Sobre os romances de Machado de Assis (ensaio crítico). Rio de Janeiro: Sociedade Editora e Gráfica Itda., s/d, p. 26.)

19 "E a conversão brusca de Guiomar, que vai dos cálculos à paixão desbordante, não é apresentada com as nuanças necessárias." (Agripino Grieco. Machado de Assis. Rio de Janeiro: Conquista, 1960, p.39)
} 
Os principais atributos do papel feminino que predominaram no século XIX foram a passividade, dependência, emocionalidade. No que se refere aos parâmetros exigidos como ideais para a mulher tradicional, (...) além de outros, ressalta 0 amor, o casamento, a virgindade, a modéstia, a submissão voluntária. Esses foram os valores que a civilização liberal cristã-burguesa ofereceu à mulher ${ }^{20}$.

Apesar de algumas vezes vermos as mulheres machadianas com uma imagem de fragilidades, frivolidade, como belas e vaidosas, elas não tiveram a vontade anulada nem cultivaram o espírito de sacrifício e abnegação. Arrisca-se a dizer que, muitas vezes, são apresentadas com características mais marcantes que as masculinas, com atitudes seguras e cheias de força moral.

Fazendo um sobrevôo pelos nove romances, percebemos que Guiomar não está sozinha na sua postura altiva.

Em Ressurreição, conhecemos Félix, homem desconfiado a ponto de ter "dúvidas póstumas", e Lívia, mulher viúva e rica, o que a coloca em uma situação de maior experiência e com certa liberdade social. No início da trama, Félix não a deixa falar e ela parece suportar com resignação suas decisões. No final, ela abandona a atitude de donzela fragilizada e toma a frente no rompimento dos laços amorosos. Helena, usando docilidade e inteligência, consegue exercer influência em todos. Está sempre trabalhando para a harmonia: conduz Estácio ao casamento com Eugênia, procura organizar o seu próprio, ajuda D. Úrsula e olha pelo pai. Iaiá Garcia manipula Jorge, Estela e Procópio Dias com o objetivo de manter a paz e a alegria de seu pai. laiá demonstra grande habilidade no jogo de relações sociais que a cerca, perdendo apenas para Guiomar porque, ao contrário da heroína de $A$ mão e a luva, acaba se apaixonando e sofrendo. Para Therezinha Mucci Xavier, "ela reflete a influência moderna, casando-se por amor e não pelo lustre de família."21

Em Memórias póstumas de Brás Cubas, Virgília casa-se com quem promete Ihe fazer marquesa. Consegue de Lobo Neves a consideração pública e de Brás Cubas, o amor. Marcela é independente e manipula seus amantes para

\footnotetext{
${ }^{20}$ Therezinha Mucci Xavier. Op. cit., p. 31.

${ }^{21}$ Idem, p. 39.
} 
conseguir presentes, jóias e dinheiro. Até Eugênia tem uma postura altiva para com Brás Cubas por não aceitar seu amor por compaixão. Em Quincas Borba, Sofia aceita ser uma peça fundamental do jogo armado por Palha e desempenha seu papel mantendo Rubião em suas mãos. Em Dom Casmurro é o próprio Bentinho quem retrata Capitu com forte, corajosa, independente e como capaz de manipulá-lo. Ao mesmo tempo, ele se coloca como fraco, dependente de sua mãe e a ela devotado. Para os parâmetros da época, quem assume as características tradicionalmente masculinas, então, parece ser Capitu.

Passando a Esaú e Jacó, encontra-se Flora, uma criatura dividida e com grande dificuldade de optar. Mas vale ressaltar, sua postura não acontece em decorrência de qualquer motivo exterior ou imposição social; não escolhe porque isso representa alguma perda. Por outro lado, D. Cláudia é forte e resoluta, emprestando sua vontade e razão a Batista. E Natividade cria seus gêmeos para serem "grandes". No último romance de Machado, observamos com D. Carmo uma outra forma de influência: ela é a esposa amorosa que promove o marido com afeto. Também é preciso falar da vontade firme de Fidélia. Ela rompe com o pai que não deseja vê-la casada com o filho de um inimigo.

Como Estela, Iaiá Garcia, Capitu e Virgília, Guiomar é dotada de inteligência, força de vontade e iniciativa para a concretização de seus planos, o que leva o narrador de $A$ mão e a luva a definir as atitudes de Guiomar, mais de uma vez como a "expressão de um gênio imperioso e voluntário"22.

Ressaltamos que isto está longe de ser uma reprovação por parte do narrador. O comportamento da heroína, que parece condenável, foi apresentado como sendo justamente o recomendável. Roberto Schwarz, em Ao vencedor as batatas, chama atenção que em $A$ mão e a luva "a terminologia do cinismo e da virtude é levada a coincidir, e o comportamento condenado é exatamente o que convém"23. É em Guiomar que esse antagonismo é mais fortemente apresentado. Ela procura de todas as formas substituir a filha perdida da baronesa, mas com

\footnotetext{
${ }^{22}$ Machado de Assis. A mão e a luva. Rio de Janeiro/Brasília: Civilização Brasileira/INL, 1975, p. 124.

${ }^{23}$ Roberto Schwarz. Ao vencedor as batatas. São Paulo: Duas cidades, 1977, p. 74.
} 
afeto sincero. Caso dissimule, é com o intuito de evitar aflição de quem a ama. Até seus cálculos não se opõem ao seu coração:

Guiomar amava deveras. Mas até que ponto era involuntário aquele sentimento? Era-o até o ponto de lhe não diminuirmos a força de suas faculdades afetivas. Até aí só; daí por diante entrava a fria eleição do espírito. Eu não a quero dar como uma alma que a paixão desatina e cega, nem fazê-la morrer de um amor silencioso e tímido. Nada disso era, nem faria. Sua natureza exigia e amava essas flores do coração, mas não havia esperar que as fosse colher em sítios agrestes e nus, nem nos ramos do arbusto modesto plantado em frente de janelas rústicas. Ela queria-as belas e viçosas, mas em vaso de Sèvres, posto sobre móvel raro, entre duas janelas urbanas, flanqueando o dito vaso e as ditas flores pelas cortinas de caxemira, que deviam arrastar as pontas da alcatifa do chão ${ }^{24}$.

Todas essas atitudes e traços de Guiomar que seriam reprováveis são anuladas, ou melhor, positivadas pelo narrador ${ }^{25}$. Guiomar é desenhada, antes de tudo, como uma personagem positiva, é a heroína que vence pela razão e que se encontra em desvantagem num mundo fechado, onde o cálculo é sua única arma de defesa.

\section{Guiomar e seus pretendentes}

Seguindo seu intuito de delinear em especial o caráter de Guiomar, Machado de Assis faz com que o narrador esclareça as boas intenções da moça em atitudes duvidosas. O autor ainda faz com que 0 narrador mostre características da heroína somente visíveis através da perspectiva de cada um de seus pretendentes.

Estevão é apresentado como um apaixonado "chorão". Já no primeiro capítulo é traçado o perfil do rapaz que será reafirmado por todo o livro: "Estevão,

\footnotetext{
${ }^{24}$ Machado de Assis. A mão e a luva. Rio de Janeiro/Brasília: Civilização Brasileira/INL, 1975, p. 138.

${ }^{25}$ Neste estudo, apenas assinalamos esta atitude do narrador. As reflexões sobre esta postura e a reação de seu público leitor ficarão para trabalhos futuros. Entretanto sugerimos ver o livro Os Leitores de Machado de Assis, de Helio de Seixas Guimarães (São Paulo: Edusp/Nankin Editorial, 2004).
} 
dotado de extrema sensibilidade, e não menor fraqueza de ânimo, afetuoso e bom, não daquela bondade varonil, que é apanágio de uma alma forte, mas dessa outra bondade mole e de cera, que vai a mercê de todas as circunstâncias (...)."26

O rapaz é a representação do amor romântico. Tal associação ainda é reforçada ao colocá-lo lendo justamente Werther, no início da trama. Entretanto, sua fraqueza de espírito, muitas vezes reafirmada durante o romance, está clara especialmente por nem conseguir ser completamente romântico. Estevão esquece a amada quanto está de volta em São Paulo e nunca consegue levar até o fim seus planos de morrer por amor. Sua postura é, inclusive, classificada como infantil: "Ele foi daqui com os olhos enxutos, distraindo-se dos tédios da viagem com alguma pilhéria de rapaz, - rapaz outra vez, como dantes." ${ }^{27}$; e adiante: "Estevão era mais ou menos o mesmo homem de dous anos antes. Vinha cheirando aos cueiros da academia (...)."28 Estevão em seu romantismo cego ainda é ridicularizado. Umas das passagens mais explícitas é a resposta de Guiomar à sua romântica declaração: "- Dou-lhe um conselho, seja homem, vença-se a si próprio; seu grande defeito é ter ficado com alma de criança."29

Apenas sob a perspectiva deste jovem romântico, o narrador encontra espaço para falar da beleza superior de Guiomar.

(...) um perfil correto e puro, como de escultura antiga. Via-lhe a face cor de leite, sobre a qual se destacava a cor escura dos cabelos, (...) a graça do talhe, que devia ser elegante, dessa elegância que nasce com a criatura ou se apura com a educação, sem nada pedir ou pedindo pouco à tesoura da costureira.(...)

Valia a pena, entretanto, contemplar aqueles grandes olhos castanhos, meio velados pelas longas, finas e bastas pestanas, não maviosos nem quebrados, como ele os cuidara ver, mas de uma beleza severa, casta e fria. Valia a pena admirar como eles comunicavam a todo o rosto e a toda a figura um ar de majestade tranqüila e senhora de si (...), tanto a arte parecia haver colaborado com a natureza naquela criatura, meia estátua e meia mulher. (...)

\footnotetext{
${ }^{26}$ Machado de Assis. A mão e a luva. Rio de Janeiro/Brasília: Civilização Brasileira/INL, 1975, p. 61.

${ }^{27}$ Idem, p. 64.

${ }^{28}$ Ibidem, p. 66.

${ }^{29}$ Idem, p. 99.
} 
Estevão, apanhado em flagrante delito de admiração, não da flor mas da mão que a sustinha, - uma deliciosa mão, que devia ser por força a que se perdeu da Vênus de Milo. ${ }^{30}$

E se sua descrição deixa transparecer algo de musa idealizada e inatingível, lembremos que é apenas a esta Guiomar que o rapaz tem acesso. Guiomar não Ihe dava qualquer esperança, era a imaginação que "multiplicava os zeros"31.

Jorge era o pretendente mais repelido pela moça e Machado nos faz acompanhá-la em sua repugnância, pintando um rapaz não feio, mas em que "a arte estragava um pouco a obra da natureza", com modos pomposos, arrumado com excessivo esmero e, por fim, com olhos que "seriam mais belos, se ele não os movesse com afetação, às vezes feminina"32. Era "um homem, cuja ridiculez compensava algumas qualidades boas."

O sobrinho da baronesa vivia da herança de seus pais, não conhecendo outra ocupação. O que oferecia a Guiomar não era mais que uma vida vegetativa e inexpressiva, oferecia a perpetuação de sua situação de favor para com a família da baronesa colocando em evidência a faceta que Guiomar mais tentava esquecer: sua situação de agregada. A partir deste instante, aflora a razão das angústias de Guiomar e a justificativa de seu comportamento calculista. Jorge coloca em dúvida se seria conveniente ao lustre da família casar-se com a moça, o que a baronesa descarta, tomando-a como filha. Também é partindo da gratidão de Guiomar à baronesa que Mrs. Oswald arquiteta seu plano: "O plano consistia em ir Jorge pedir a moça à baronesa, em presença dela própria. A Baronesa, que nutria o desejo de os ver casados, não deixaria de fazer pesar seu voto na balança (...)."34 Jorge, da sua confortável posição de quem presta o favor ao agregado, compreende onde Mrs. Oswald quer chegar e executa o plano, consciente da sua situação favorável. O resultado da intriga é o sentimento de

\footnotetext{
${ }^{30}$ Ibidem, p. 70, 72 e 74.

${ }^{31}$ Idem, p. 94.

${ }^{32}$ Ibidem, p. 93.

${ }^{33}$ Idem, p. 108.

${ }^{34}$ Ibidem, p. 139.
} 
humilhação de Guiomar, que há bastante tempo não é uma "simples herdeira da pobreza de seus pais"35, ela age e responde à situação como uma aristocrata:

Nenhuma consulta, nenhuma autorização prévia; parecia-lhe que a tratavam como ente absolutamente passivo, (...).

(...) não esquecia os benefícios recebidos, mas quisera que lhos não lembrassem por meio de uma violência: faze-lo, era o mesmo que lançar-lhos em rosto.

- Não! Murmurava enfim a moça, forçar-me, reduzir-me à condição de simples serva, nunca ${ }^{36}$.

Luís Alves é o ultimo a se declarar pretendente, na trama. Inicialmente o caráter do rapaz é revelado em comparação ao de Estevão, que chega a ser cômico em contraste com a inteligência clara e a força valorizadas em Luís Alves e Guiomar. Desde sua primeira descrição, quando ainda era estudante de Direito, o narrador assinala a diferença dos rapazes. Luís "tinha o seu grão de egoísmo, e se não era incapaz de afeições, sabia regê-las, moderá-las, e sobretudo guiá-las ao seu próprio interesse." ${ }^{37}$ Durante a trama, esta racionalidade, superior aos sentimentos, vai sendo reafirmada:

Luís Alves admirou-se de o ver; não foi com um espanto de seis dias, como devera ser, mas de quarenta e oito horas, quando muito. Que admira? A preocupação de Luís Alves por aqueles dias era a candidatura eleitoral (...). Ora, em boa razão, um homem que está prestes a ser inscrito nas tábuas do Parlamento, não pode cogitar muito dos amores de um rapaz, ainda que o rapaz seja amigo e os amores verdadeiros ${ }^{38}$.

Da metade para o final do romance, o foco do narrador é cada vez mais recorrente sobre Luís Alves. Revela-se um homem que conhece os códigos de comportamento social e sabe usá-los em seu favor, como nesta passagem: "toda a arte em suma de tratar os homens, de os atrair e de os namorar, que ele aprendera cedo e que the devia aproveitar mais tarde na vida pública." ${ }^{39}$ À

\footnotetext{
35 Idem, p. 79.

${ }^{36}$ Ibidem, p. 147.

37 Idem, p. 61.

38 Ibidem, p. 118-9.

39 Idem, p. 122.
} 
inteligência vão se somando outros atributos como a observação, o cálculo, a presença de espírito e, ainda, a capacidade de dissimulação e domínio dos sentimentos. Estamos diante do espelho de Guiomar, e não poderia ser diferente, ou não seriam a mão e a luva.

Se o cálculo e a dissimulação estão associados à moça desde o princípio, é a partir do momento que o advogado torna-se pretendente que a ambição da moça torna-se explícita: "- Não há dúvida; é uma ambiciosa." ${ }^{\text {"40 }}$ E logo adiante ele próprio será definido assim: "Amor um pouco sossegado, não louco e cego como o de Estevão, não pueril e lascivo como o de Jorge, um meio-termo entre um e outro, - como podia havê-lo no coração de um ambicioso.".41 (nosso grifo) Sabemos que ele é o escolhido de Guiomar, pois, "em torno dele ia fazer-se aquela luz, que era a ambição da moça, a atmosfera, que ela almejava respirar.."42. A partir daí, aparecem várias aproximações textuais entre Luís e Guiomar, algo que não ocorre em relação aos outros dois pretendentes:

\begin{tabular}{|c|c|}
\hline $\begin{array}{l}\text { "Ela queria um homem que (...) } \\
\text { sentisse dentro de si a força bastante } \\
\text { para subi-la aonde a vissem todos os } \\
\text { olhos." (ASSIS, 1975, p.130) }\end{array}$ & $\begin{array}{l}\text { "Estava Luís Alves deputado".(ASSIS, } \\
\text { 1975, p.135) }\end{array}$ \\
\hline $\begin{array}{l}\text { "No rosto de Guiomar podemos nós ler } \\
\text { (...) a expressão de um gênio } \\
\text { imperioso e voluntário." (DE ASSIS, } \\
\text { 1975, p.124) }\end{array}$ & $\begin{array}{l}\text { "Luís Alves compreendera toda a } \\
\text { expressão nos olhos de Guiomar; era, } \\
\text { porém, homem frio e resoluto." (DE } \\
\text { ASSIS, 1975, p.126) }\end{array}$ \\
\hline $\begin{array}{l}\text { "A primeira impressão fora profunda, } \\
\text { mas Guiomar tinha força bastante para } \\
\text { dominar-se e fechar todo o sentimento } \\
\text { no coração." (DE ASSIS, 1975, p.134) }\end{array}$ & $\begin{array}{l}\text { "Esta presença de espírito de Luís } \\
\text { Alves ia muito com o gênio de } \\
\text { Guiomar; era um laço de simpatia." } \\
\text { (DE ASSIS, 1975, p.126 §540) e "Nem }\end{array}$ \\
\hline
\end{tabular}




\begin{tabular}{|c|c|}
\hline & $\begin{array}{l}\text { o gesto da moça, nem a surpresa das } \\
\text { outras pessoas perturbou o advogado; } \\
\text { Luís Alves inclinou-se para o mocho, } \\
\text { como a consertá-lo". (DE ASSIS, 1975, } \\
\text { p.133-134) }\end{array}$ \\
\hline $\begin{array}{l}\text { "Guiomar amava deveras. (...) Era-o } \\
\text { até o ponto de lhe não diminuirmos a } \\
\text { força de suas faculdades afetivas. Até } \\
\text { aí só; daí por diante entrava a fria } \\
\text { eleição do espírito." (DE ASSIS, 1975, } \\
\text { p.138, nosso grifo) }\end{array}$ & $\begin{array}{l}\text { "Esta incerteza abalou-o mais do que } \\
\text { ele supunha; e foi, sem dúvida, a } \\
\text { primeira ocasião em que sentiu que a } \\
\text { amava deveras, ainda que o seu amor } \\
\text { fosse como ele mesmo: plácido e } \\
\text { senhor de si." (DE ASSIS, 1975, p.135, } \\
\text { nosso grifo) }\end{array}$ \\
\hline
\end{tabular}

Por fim, se Guiomar inúmeras vezes é flagrada utilizando o cálculo, Luís Alves prende-se ao método. Ambos análogos na representação da racionalidade dessas personagens, na expressão de sua capacidade de participar ativamente do jogo de interesses do ambiente social em que vivem. As semelhanças narradas até o final colocam os dois em harmonia e prepara o desfecho inevitável em que as duas ambições se uniram e "trocaram o ósculo fraternal"43 (nosso grifo).

Vale ressaltar que, além do narrador assumir a perspectiva dos pretendentes para nos mostrar várias facetas de Guiomar, ele ainda cede lugar à própria moça para que se apresente por ela mesma:

- (...) Nunca vulgarizei meu espírito. (...)

Saiba pois que sou muito senhora da minha vontade, mas pouco amiga de a exprimir, quero que me adivinhem e obedeçam; sou também um pouco altiva, às vezes caprichosa, e por cima de tudo isto tenho um coração exigente. ${ }^{44}$

Guiomar era uma jovem solteira e, ainda, agregada, categoria social típica do século XIX brasileiro e personagem contumaz no romance machadiano, cuja

\footnotetext{
${ }^{43}$ Idem, p. 162.

${ }^{44}$ Ibidem, p. 158.
} 
figuração maior encontra-se no agregado José Dias, em Dom Casmurro. Não é verdade que, em alguma medida, ao apresentá-la pela perspectiva de seus pretendentes, o narrador está ratificando sua condição social? Por isso mesmo, destacamos esta passagem, pois a auto-apresentação de Guiomar acompanha justamente o momento em que, por esforço da própria heroína, ocorre a superação dessa condição: ela se casará com o pretendente que ela escolheu, deixará de ser agregada e não perderá status social. Mais que um contraste de caracteres, vemos assim surgir no romance o percurso de "emancipação" de Guiomar.

A apresentação de Guiomar por tantas facetas torna complexa sua compreensão. H. Pereira da Silva, ao criticar o excesso de maturidade do pensamento da moça, e Agrippino Grieco, ao não entender o amor de Guiomar nascido dos cálculos, mostram que não houve uma sensibilidade para perceber a forma de apresentação da personagem neste romance. Como personagem de ficção, Guiomar não pode ser avaliada por sua equivalência a uma jovem da segunda metade do século XIX, mas por seu estado de desenho de caráter, que apesar de pintado não convencionalmente pelo autor, não é inverossímil.

Existe, de fato, uma excessiva preocupação em desvendar Guiomar, tendo o narrador não apenas a preocupação de mostrar suas características e ações, mas inclusive de interpretá-las para o leitor. Lembremos que Anatol Rosenfeld, em "Literatura e personagem", aponta esse detalhamento que constrói a aparência de verdade como aquilo que mais caracteriza a ficção: "É paradoxalmente esta intensa 'aparência' de realidade que revela a intenção ficcional ou mimética. (...) É porém a personagem que com mais nitidez torna patente a ficção, e através dela a camada imaginária se adensa e se cristaliza." 45

\section{Guiomar e a princesa}

\footnotetext{
45 Anatol Rosenfeld. "Literatura e personagem". In. A personagem de ficção. São Paulo: Perspectiva, 1976, p. 20-1.
} 
Curiosamente, encontramos na estória de Guiomar ecos da trama do romance A princesa de Clèves, de Madame de Lafayette. Dois século antes de Machado de Assis, a escritora francesa abordou o conflituoso tema da escolha de um casamento pela razão e não pelo amor e o quanto este evento estava relacionado com a colocação social de uma moça.

O romance francês é publicado em 1678, na revista Mercure Galant, sem a assinatura da autora. Teve várias reedições e adaptações para teatro e cinema. Como pano de fundo ocorre a descrição complexa das relações pessoais na corte de Henrique II, na França do século XVI. O livro é tomado pelo desenrolar da trama de interesses pessoais e políticos, onde está em jogo favoritismo e poder, que se estabelecem através das associações, da ligação à pessoa certa. São verdadeiros grupos de força que se formam na corte de Henrique II, onde o casamento e a galantaria aparecem como meio eficaz de estabelecer posição social.

A ambição e a galantaria eram a alma da corte e ocupavam igualmente a atenção dos homens e das mulheres. Havia tantos interesses e cabalas, com a participação das senhoras, que o amor sempre se misturava aos negócios e os negócios ao amor. Ninguém se sentia tranqüilo ou indiferente. Pensava-se em se elevar, em agradar, em servir ou prejudicar. Ninguém conhecia tédio ou ociosidade: havia sempre prazeres ou intrigas. As senhoras se apegavam particularmente à rainha, à rainha-delfina, à rainha de Navarra, à irmã do rei ou à duquesa de Valentinois ${ }^{46}$.

A princesa é uma jovem de 16 anos, de beleza perfeita e severamente educada pela mãe, casa-se com um fidalgo que a ama perdidamente, enquanto ela apenas o estima. Pouco tempo depois desse casamento definido pela razão, a jovem apaixona-se por um nobre sedutor que a corteja insistentemente. Tal sentimento leva a princesa a um profundo conflito consigo mesma, com seu marido e com a sociedade.

A princesa de Clèves é apresentada como alguém que não conhece 0 código da vida na corte, ou, pelo menos, que não sabe manipulá-lo: "Havia assim

\footnotetext{
${ }^{46}$ Madame de Lafayette. A Princesa de Clèves. Rio de Janeiro: Record, 2004, p. 34-5.
} 
uma espécie de agitação sem desordem na corte que a tornava agradável, mas também perigosa a uma pessoa jovem." ${ }^{47}$ Inicialmente, a responsável pela direção de seu comportamento e pela instrução a respeito da corte é sua mãe, a Senhora de Chartres. Entretanto, sua morte deixa a princesa sem o apoio necessário para a vida na corte. A incapacidade da princesa de lidar com o complexo jogo de interesses, ao mesmo tempo políticos e amorosos, chega à conseqüência máxima de confessar-se ao marido apaixonada por outro homem.

- Pois bem - disse ela, caindo de joelhos -, vou fazer uma confissão que nunca se fez a um marido. Mas a inocência de meu comportamento e de minhas intenções me dá força. É verdade que tenho motivos para afastar da corte e desejo evitar os perigos que às vezes rondam as pessoas da minha idade. Jamais dei provas de fraqueza. Nem as aparentaria se ganhasse a liberdade de me afastar ou se ainda tivesse minha mãe para me valer. Por mais arriscada que seja esta minha resolução, tomo-a com alegria para me conservar digna de meu marido. Peço-Ihe mil perdões se tenho sentimentos que o desagradam. Ao menos, nunca o desagradarei pelos meus atos. Pense que para fazer o que faço é preciso muita amizade e estima por um marido como jamais se teve. Tenha piedade de mim, ama-me ainda, se puder ${ }^{48}$.

O conflito da princesa é algo tomado como bastante estranho às práticas amorosas usuais da corte. Sobre o amor, a paixão e a inclinação, havia praticamente um acordo tácito de que poderiam ser satisfeitos independente do casamento. O prenúncio da falta de sucesso do casamento do príncipe de Clèves é justamente o fato de ele acreditar que conseguiria mais que a união com um bom partido, conseguiria a felicidade no amor. Da mesma forma, a culpa da princesa é justamente por não corresponder ao marido: "Ela não sabia o que responder. (...) O príncipe percebia o quanto ela estava longe de nutrir por ele sentimentos que poderiam satisfazê-lo." ${ }^{49} \mathrm{E}$ mais adiante: "A senhora é minha mulher, amo-a como se fosse uma amante e a vejo, no entanto, amar outro." 50

O casamento é apresentado como o objetivo maior de todas as mulheres da corte, inclusive da senhorita de Chartres. Mas este casamento devia ser com

\footnotetext{
47 Idem, p. 35.

48 Ibidem, p. 122.

49 Idem, p. 41.

50 Ibidem, p. 153.
} 
um homem de expressão, de preferência com um primogênito de uma casa ilustre, ou seja, devia ser uma união de conveniência social. Parece não haver muita distancia da corte francesa de Henrique II para a alta sociedade carioca do segundo reinado.

Como em A mão e a luva, o romance de Madame de Lafayette traz a representação da complexa relação pessoal em um ambiente fechado em que estão em relevo o favoritismo, o poder e em que o casamento é uma arma e não uma experiência amorosa. Ressalta-se, ainda, que tanto a princesa como Guiomar estabelecem um percurso rumo à independência: Guiomar trabalha no rompimento dos laços de favor que a ligam à baronesa, alcançando a imposição de sua vontade e o estabelecimento de uma situação social favorável; a princesa caminha em direção à construção de sua interioridade e sua autodireção, independentemente da mãe ou do marido.

Ao mesmo tempo são personagens antagônicas, não apenas porque, ao contrário da princesa, Guiomar consegue aliar o amor à razão no casamento com Luís Alves. Mas, porque a princesa, além de agir com insegurança em sociedade, ela progressivamente, durante a trama, vai se afastando do ambiente da corte em um movimento de rejeição de participação do seu jogo. Por sua vez, Guiomar, conhece muito bem os códigos do mundo em que vive e os manipula. Ela também está em um mundo fechado e sabe que precisa estabelecer as ligações devidas para romper com sua situação de agregada. É capaz de calcular tão bem as ações essenciais à realização de seu objetivo que agencia seu próprio casamento: "um bom negócio", tanto para ela quanto para o noivo.

Com relação às soluções narrativas também é possível estabelecer um curioso paralelo. A princesa de Clèves é considerado o primeiro romance moderno da literatura francesa e é caracterizado como um romance psicológico. Ao contrário de interromper a ação para que as personagens se analisassem, Madame de Lafayette faz com que esses momentos se tornem parte da progressão da trama e essenciais para o desenrolar da narrativa. O narrador onisciente, relator de fatos e ações, muitas vezes abandona esta postura para cuidar do universo interior das personagens. E, já a caminho do final do romance, 
quando a tensão é maior e os conflitos da princesa parecem se tornar mais complexos, o narrador se mistura ao pensamento das personagens chegando a passar da terceira para a primeira pessoa em algumas passagens:

Espantou-se de não haver ainda pensado como era pouco verossímil que um homem como o senhor de Nemours, considerado leviano no trato com as mulheres, fosse capaz de afeto sincero e durável. Achou que era quase impossível se contentar com sua paixão. Mas, perguntava-se, que farei se me apaixonar? Sofrerei? Corresponderei? Quero me comprometer com uma galantaria? Enganar o senhor de Clèves? Enganar a mim mesma? Expor-me, enfim, aos cruéis arrependimentos e às dores morais do amor? Fui vencida e ultrapassada por uma inclinação que me arrasta contra a vontade. Todas as minhas resoluções são inúteis. Planejei ontem tudo o que faria hoje e faço hoje o contrário do que resolvi ontem. Tenho de evitar a presença do senhor de Nemours. Tenho de ir para o campo, por mais estranha que a viagem pareça. Se o senhor de Clèves se obstinar em impedir a viagem ou em conhecer os motivos, talvez lhe dê o desgosto, e a mim também, de contar a verdade.

Manteve-se nessa determinação e ficou em casa toda a tarde $(. . .)^{51}$.

Paralelamente, em $A$ mão e a luva, vemos o narrador emprestar seu lugar aos pretendentes e a própria Guiomar na apresentação da moça. À medida que os outros personagens ganham definição, logo conhecemos mais uma faceta da heroína, somente revelada na perspectiva da personagem em foco. E, assim, conhecemos a Guiomar como perfeita musa romântica; em seguida como agregada que deseja romper os laços de favor; e como a mulher ideal para um homem público forte, ambicioso e de futuro. Tal configuração da personagem que a princípio pareceria fragmentária tem, ao contrário do que se espera, um efeito harmonioso ao longo do romance, em decorrência do fato de serem, na verdade, quadros diferentes de uma mesma mulher, vista por mais de um ângulo, inclusive por ela mesma. Machado cumpre a promessa do prefácio de tomar como objeto principal a pintura do caráter de Guiomar. A ação que se desenrola sobre o agenciamento do casamento da afilhada da baronesa "cabe como uma luva" para que o autor lançasse os contornos dos perfis e mostrasse o percurso de um caráter forte a caminho da sua libertação.

\footnotetext{
51 Idem, p. 119.
} 
Como foi visto, Guiomar faz parte de um instigante grupo de personagens femininas de Machado de Assis, entretanto vale assinalar que a complexidade de sua construção a coloca no rol de importantes personagens femininas da literatura, do qual faz parte justamente a princesa de Clèves. Arrisca-se a dizer que, agora, é Machado de Assis e Madame de Lafayette que se aproximam, aceitando o desafio de voltar ao tema das ligações amorosas e de falar de todas as implicações que podem cercar o casamento de uma jovem. Os cenários sociais pintados curiosamente se aproximam muito, apesar de estarem separados por dois séculos. Ambos os autores conseguiram sensíveis abordagens e novas soluções narrativas, que fazem das obras objetos obrigatórios no estudo do romance.

\section{Referência Bibliográfica}

ASSIS, Joaquim Maria Machado de. A mão e a luva. Rio de Janeiro: Civilização Brasileira; Brasília: INL, 1975. Ressurreição. Rio de Janeiro: Civilização Brasileira; Brasília: INL, 1975. Helena. Rio de Janeiro: Civilização Brasileira; Brasília: INL, 1975. laiá Garcia. Rio de Janeiro: Civilização Brasileira; Brasília: INL, 1975. - Memórias póstumas de Brás Cubas. 2. ed. Rio de Janeiro: Civilização

Brasileira; Brasília: INL, 1977. . Dom Casmurro. Rio de Janeiro: Civilização Brasileira; Brasília: INL, 1975. . Quincas Borba. Rio de Janeiro: Civilização Brasileira; Brasília: INL, 1975. . Esaú e Jacó. Rio de Janeiro: Civilização Brasileira; Brasília: INL, 1975.

1975. - Memorial de Aires. Rio de Janeiro: Civilização Brasileira; Brasília: INL,

GRIECO, Agrippino. Machado de Assis. Rio de Janeiro: Conquista, 1960.

LAFAYETTE, Madame de. A princesa de Clèves. Rio de Janeiro: Record, 2004.

MACHADO, Ubiratan. Machado de Assis: roteiro de consagração. Rio de Janeiro: EdUERJ, 2003. 
ROSENFELD, Anatol. "Literatura e Personagem". CÂNDIDO, Antônio, ROSENFELD, Anatol, PRADO, Décio de Almeida e GOMES, Paulo Emílio Salles. A personagem de fiç̧ão. São Paulo: Ed. Perspectiva, 1976.

SCHWARZ, Roberto. Ao Vencedor as Batatas. São Paulo: Duas cidades, 1977.

SILVA, H. Pereira da. Sobre os romances de Machado de Assis (ensaio crítico). Rio de Janeiro: Sociedade Editora e Gráfica Ltda, s/d.

STEIN, Ingrid. Figuras femininas em Machado de Assis. Rio de Janeiro: Paz e Terra, 1984.

XAVIER, Therezinha Mucci. A personagem feminina no romance de Machado de Assis. Rio de Janeiro: Presença, 1986. 